\title{
ZOOTAXA
}

\section{Taxonomy and distribution of sea anemones (Cnidaria: Actiniaria and Corallimorpharia) from deep water of the northeastern Pacific}

\footnotetext{
WENDY E. EASH-LOUCKS ${ }^{1,2} \&$ DAPHNE G. FAUTIN ${ }^{1}$

${ }^{\prime}$ Department of Ecology and Evolutionary Biology, University of Kansas, and Division of Invertebrate Zoology, University of Kansas Natural History Museum and Biodiversity Institute, 1200 Sunnyside Avenue, Lawrence, KS 66045, USA. E-mail: weashloucks@gmail.com; fautin@ku.edu

${ }^{2}$ Current address: Guana Tolomato Matanzas National Estuarine Research Reserve, 505 Guana River Road, Ponte Vedra Beach, FL 32082, USA.
}

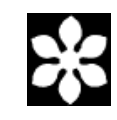

Magnolia Press

Auckland, New Zealand 
WENDY E. EASH-LOUCKS \& DAPHNE G. FAUTIN

Taxonomy and distribution of sea anemones (Cnidaria: Actiniaria and Corallimorpharia) from deep water of the northeastern Pacific

(Zootaxa 3375)

80 pp.; $30 \mathrm{~cm}$.

4 Jul. 2012

ISBN 978-1-86977-947-4 (paperback)

ISBN 978-1-86977-948-1 (Online edition)

FIRST PUBLISHED IN 2012 BY

Magnolia Press

P.O. Box 41-383

Auckland 1346

New Zealand

e-mail: zootaxa@mapress.com

http://www.mapress.com/zootaxa/

(C) 2012 Magnolia Press

All rights reserved.

No part of this publication may be reproduced, stored, transmitted or disseminated, in any form, or by any means, without prior written permission from the publisher, to whom all requests to reproduce copyright material should be directed in writing.

This authorization does not extend to any other kind of copying, by any means, in any form, and for any purpose other than private research use.

ISSN 1175-5326 (Print edition)

ISSN 1175-5334 (Online edition) 


\section{Table of contents}



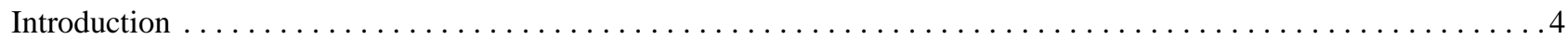

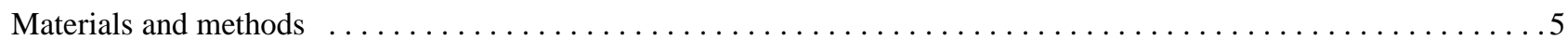



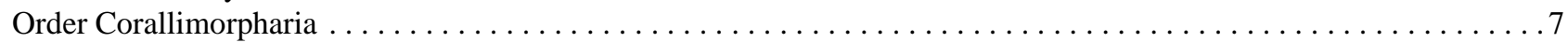



Corallimorphus denhartogi Fautin, White, and Pearson, $2002 \ldots \ldots \ldots \ldots \ldots \ldots \ldots \ldots \ldots \ldots \ldots$







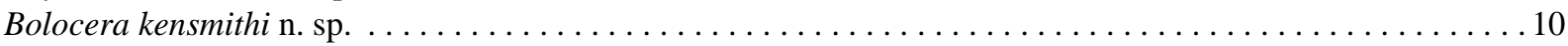







Anthosactis nomados White, Wakefield Pagels, and Fautin, $1999 \ldots \ldots \ldots \ldots \ldots \ldots \ldots$

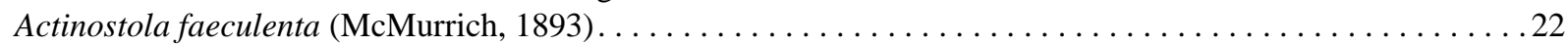

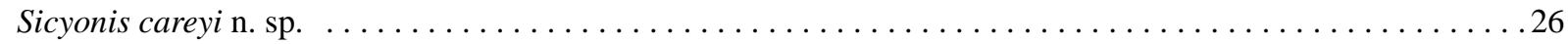





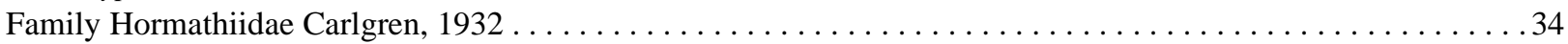



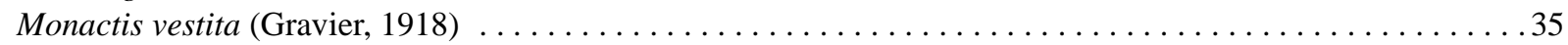

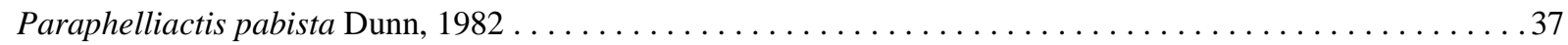







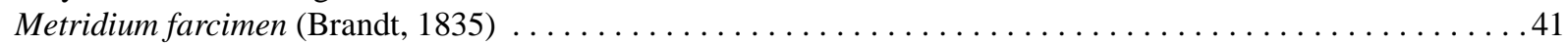

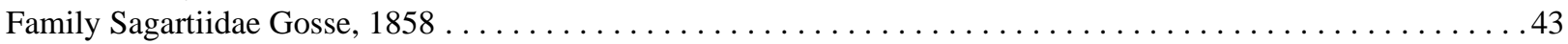





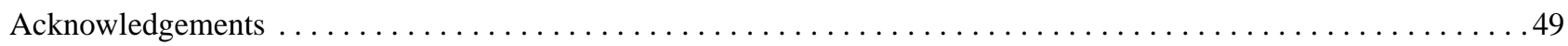

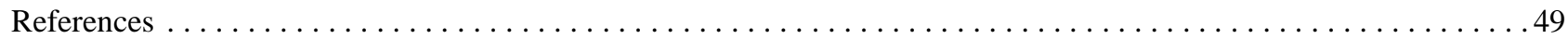

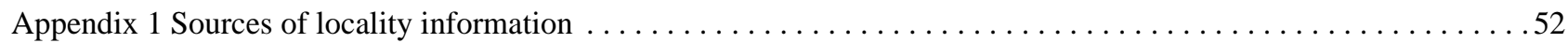

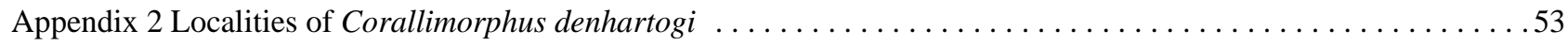



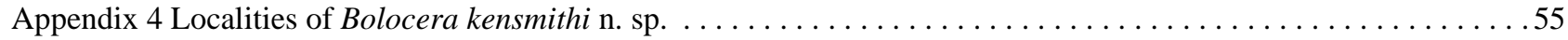



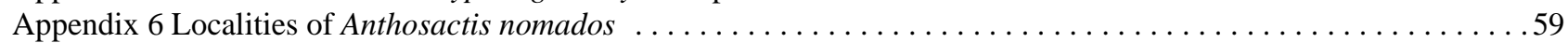

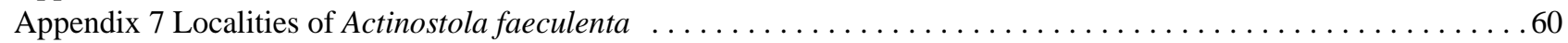



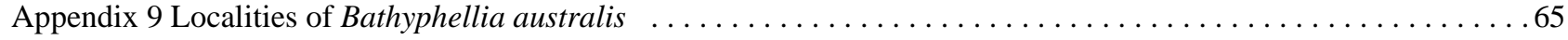

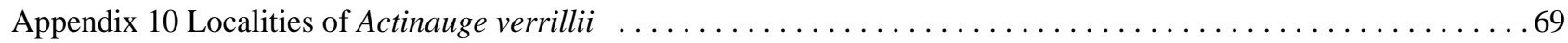

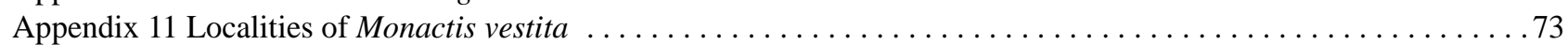












\begin{abstract}
Sea anemones sensu lato (members of cnidarian orders Actiniaria and Corallimorpharia) occurring in water of the northeastern Pacific Ocean greater than $1,000 \mathrm{~m}$ (to the abyssal plain) are poorly known. Based on the literature and specimens we examined in the four largest collections of animals from this area, we estimate that approximately 35 species occur in these deep-water habitats and fewer than half have been documented there. Of the largest and most abundant epibenthic species, based on morphology, we identified two species of Corallimorpharia (both previously known) and 12 of Actiniaria (three new). Half the sea anemone species are widely distributed: Actinauge verrillii McMurrich, 1893, Actinoscyphia groendyki n. sp., Actinostola faeculenta (McMurrich, 1893), Bathyphellia australis Dunn, 1983, Liponema brevicorne (McMurrich, 1893), Metridium farcimen (Brandt, 1835), and Monactis vestita (Gravier, 1918). The others are known only from the northeastern Pacific Ocean: Corallimorphus pilatus Fautin, White, and Pearson, 2002, Corallimorphus denhartogi Fautin, White, and Pearson, 2002, Anthosactis nomados White, Wakefield Pagels, and Fautin, 1999, Bolocera kensmithi n. sp., Paraphelliactis pabista Dunn, 1982, Sagartiogeton californicus (Carlgren, 1940) (for which we designate a neotype), and Sicyonis careyi n. sp. A naturally occurring oxygen minimum zone (OMZ) off Oregon is expanding, and the marine life living within its virtually anoxic areas is threatened. Nine of the species we examined occur within the current depth range of the OMZ and may be threatened if the OMZ continues to strengthen and expand.
\end{abstract}

Key words: Biogeography, Coelenterata, Hexacorallia, Bathyal, Abyssal

\title{
Introduction
}

Animals belonging to cnidarian orders Actiniaria and Corallimorpharia (sea anemones sensu lato) in deep waters of the northeastern Pacific Ocean are poorly known. By contrast, the intertidal and shallow subtidal fauna of the area has been well studied; about 30 species have been documented in shallow habitats (e.g. Gotshall 1994; Fautin $\&$ Hand 2007). We used morphological characters to identify specimens previously collected on the continental slope and abyssal plain. We estimate, based on the literature and the four largest museum collections of these animals, that about 35 species of anemones occur from southern California to northern British Columbia at 1,000 m and deeper. We provide an inventory of the 14 largest and most abundant epibenthic species: 12 actiniarians, three of which we describe as new species, and two corallimorpharians. In addition, as part of our consideration of Sicyonis, we move from that genus the species now properly known as Parasicyonis biotrans (Riemann-Zürneck, 1991).

Aside from contributing to basic knowledge of marine biodiversity (Cressey 2010), this inventory may be useful in assessing the impact of the oxygen minimum zone (OMZ) off the coast of Oregon that is expanding in space and time (Chan et al. 2008; Gewin 2010). Because many of the specimens on which it is based were collected in the 1970s and 1980s, before the expansion of the OMZ, this inventory of the anemones of the deep northeastern Pacific Ocean can be used as a baseline for comparison in future biotic inventories in the OMZ to determine if expansion of the OMZ has affected sea anemones.

Ekman (1953) reported that many deep-sea taxa are widely distributed. Vinogradova (1959) refined that generalization by considering taxonomic rank; she discovered in an analysis of 1,031 species from around the world at deeper than 2,000 $\mathrm{m}$ that at the generic level faunas are similar, but endemicity is high at the species level. Similarly, Rodríguez et al. (2007) found that all 31 families of anemones in the Southern Ocean (including the SubAntarctic [Deacon 1982; Rodríguez et al. 2007]), as well as 75\% of the genera, have representatives elsewhere in the world, but $75 \%$ of the species are endemic. The wide distribution of higher taxa in the deep sea is likely due to connectivity of the waters due to thermohaline circulation, termed by Broecker (1991) the great ocean conveyor.

We found that all families, as well as $92 \%$ of the genera (all except Paraphelliactis Carlgren, 1928b), have representatives outside the Pacific Ocean, but that $71 \%$ of the species are endemic to the North Pacific. Of the new species of Actiniaria we identified, Bolocera kensmithi n. sp. and Sicyonis careyi n. sp. are known only from the northeastern Pacific Ocean, and Actinoscyphia groendyki n. sp. is found in both the North Pacific and Southern Oceans. In addition to the northeastern Pacific, Actinauge verrillii McMurrich, 1893, and Bathyphellia australis Dunn, 1983, have been recorded in the Southern Ocean, and Monactis vestita (Gravier, 1918) has been recorded in the Atlantic. The remaining species are known only from the North Pacific. Three occur on both the east and west sides of that ocean basin: Actinostola faeculenta (McMurrich, 1893), Liponema brevicorne (McMurrich, 1893), and Metridium farcimen (Brandt, 1835). All others are endemic to the northeastern Pacific Ocean: Corallimorphus denhartogi Fautin, White, and Pearson, 2002, Corallimorphus pilatus Fautin, White, and Pearson, 2002, 
Anthosactis nomados White, Wakefield Pagels, and Fautin, 1999, Paraphelliactis pabista Dunn, 1982, and Sagartiogeton californicus (Carlgren, 1940).

\section{Materials and methods}

We examined 8,226 specimens in 934 lots representing 14 species. Most specimens were collected by beam and otter trawls in the northeastern Pacific Ocean from southern California to British Columbia to a depth of 4,325 m. Many were collected during studies off the coast of Oregon in the 1960s and 1970s by Andrew G. Carey, Jr. of Oregon State University (e.g. McCauley \& Carey 1967; Carney \& Carey 1982), and approximately $200 \mathrm{~km}$ off the coast of southern California at Station M (Smith et al. 1994) in the 1990s by Kenneth L. Smith, Jr., then of Scripps Institution of Oceanography (now at the Monterey Bay Aquarium Research Institute, Moss Landing, California [MBARI]). Most of Carey's specimens are held at the Santa Barbara Museum of Natural History, Santa Barbara, California, USA (SBMNH), and Smith's are in the Division of Invertebrate Zoology of the University of Kansas Biodiversity Institute, Lawrence, Kansas, USA (KUIZ). Specimens collected by the Department of Fisheries and Oceans of Canada (DFO) from the 1970s through the early $21^{\text {st }}$ century were examined at the Royal British Columbia Museum, Victoria, British Columbia, Canada (RBCM) and California Academy of Sciences, San Francisco, California, USA (CAS). We examined other relevant specimens in these museums, and a syntype of Actinange verrillii from the US National Museum of Natural History, Washington, DC, USA (USNM).

Histological sections were prepared by embedding specimens in Paraplast ${ }^{\circledR}$, sectioning at $8-12 \mu \mathrm{m}$, and staining with hematoxylin and eosin (Humason 1967).

Undischarged cnidae were measured from squash preparations of tissue from tentacles, column, actinopharynx, acontia, and mesenterial filaments at 1,000x using a compound light microscope equipped with differential interference contrast (Nomarski) optics. Cnidae were not measured from the column of animals that were devoid of ectoderm, a state common in deep-sea anemones (Carlgren 1956; Fautin \& Hessler 1989; RiemannZürneck 1994; White et al. 1999). Nematocyst identification was based on Fautin (1984), and the terms robust and gracile are used to describe two morphologically distinct types of spirocysts (Arellano \& Fautin 2001). In tables displaying nematocyst measurements, "N" represents the fraction of animals examined that contained a particular type of cnida, and " $n$ " represents the total number of capsules measured. Letters refer to image of the corresponding cnida in the cited figure.

We provide complete taxonomic descriptions for the new species, and similar information for Sagartiogeton californicus, the original description of which was excessively short. We briefly discuss the other species and add information on their distributions, based on specimens examined. A dichotomous key to the deep northeastern Pacific anemones is based on our research; a dichotomous key distinguishing each new species we describe from its congeners is based on published descriptions and redescriptions for the species that we did not examine. Species treatments of members of order Corallimorpharia are first. Families are alphabetical in each order, as are genera in each family.

Appendices contain lists of specimens examined or cited from the literature. Abbreviations for museums holding specimens that we did not examine for this study are CMN (Canadian Museum of Nature, Ottawa, Ontario, Canada), LACM (Natural History Museum of Los Angeles County, Los Angeles, California, USA), MCZ (Harvard Museum of Comparative Zoology, Cambridge, Massachusetts, USA), MLML (Moss Landing Marine Laboratory, Moss Landing, California, USA), MOM (Musée Océanographique de Monaco, Monaco-Ville, Monaco), MZLU (Museum of Zoology, Lund University, Lund, Sweden), RMNH (Nationaal Natuurhistorisch Museum, Leiden, The Netherlands), SIO (Scripps Institution of Oceanography, La Jolla, California, USA), and YPM (Yale Peabody Museum of Natural History, New Haven, Connecticut, USA). Type status abbreviations are H (holotype), S (syntype[s]), P (paratype[s]), and $\mathrm{N}$ (neotype). Specimens are arranged geographically, south to north; descriptive localities, to the highest detail possible, are given for those lacking coordinates.

Distribution maps were created with ArcInfo using locality data from specimens examined and the literature. For specimens lacking coordinates, we used the georeferenced value for the named locality in the Hexacorallians of the World database (Fautin 2011), if present. If not, the locality is the centroid for the cruise on which the specimen was collected, or, if depth is known, an estimate from nautical charts (US National Oceanographic and Atmospheric Administration: NOAA) based on the depth at which the specimen was collected. On distribution 
maps, localities of specimens of documented latitude, longitude, and depth data are represented as circles; estimated localities are represented as triangles. Solid symbols are new localities, and a previously published locality is an open symbol with a dot in the center. Depths are in meters: average depth is used if a depth range is provided, and depth is estimated from the ETOPO2 $\left(2^{12}\right)$ bathymetry data set (National Geophysical Data Center 2006) for specimens lacking depth information.

\section{Dichotomous key to sea anemones of the deep of northeastern Pacific}

The following key is based on both external and internal morphology and can be used to identify some species from photos. Every effort was made to be sufficiently precise so that animals belonging to species other than the 14 included in this study will not be misidentified as one of the 14 .





2 Column discoidal. About 72 tentacles; marginal and discal tentacles in an approximate $2: 1$ ratio $\ldots \ldots \ldots \ldots \ldots \ldots$

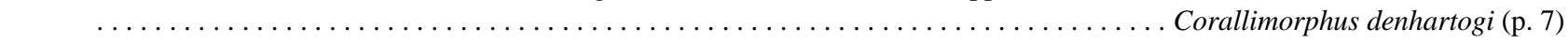
Column cylindrical. About 130 tentacles; marginal and discal tentacles occur in an approximate $4: 1$ ratio . ...........



3 Color pink to orange to tan in life and preservation. Tentacles deciduous; when tentacles are cast off, pore marks position of each. Marginal sphincter muscle endodermal $\ldots \ldots \ldots \ldots \ldots \ldots \ldots \ldots \ldots \ldots \ldots \ldots \ldots \ldots \ldots \ldots \ldots \ldots \ldots$



4 Column conspicuous, somewhat narrower than oral disc. About 48 tentacles arrayed along margin, one tentacle connecting


Column short, hidden beneath dome of oral disc, margin of which extends to level of column base. Several hundred tentacles cover oral disc that is much broader than column, more than one tentacle connecting with each exocoel ...

............ Liponema brevicorne (p. 40)

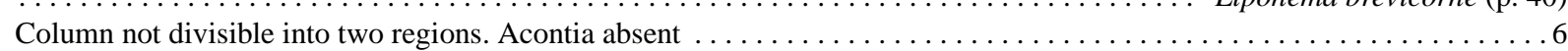
Column divisible into two regions (scapus and scapulus, or scapus and capitulum). Acontia present $\ldots \ldots \ldots \ldots \ldots$

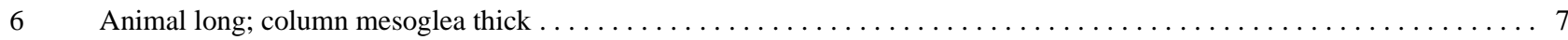
Animal flat, attached to scaphopod shell. Column mesoglea thin .................. Anthosactis nomados (p. 21)

7 Tentacles cover at least half of oral disc. More than six pairs of mesenteries complete; members of young mesentery pairs not


Tentacles restricted to margin, thickened aborally at base. Six pairs of mesenteries complete; members of young mesentery pairs equally developed. . . . . . . . . . . . 15)

8 Column bumpy; typically tapers from distal to proximal end. To more than 200 tentacles. Mesenteries most numerous distally

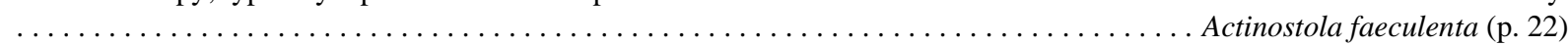
Column smooth; typically cylindrical. About 80 tentacles. Mesenteries most numerous proximally .

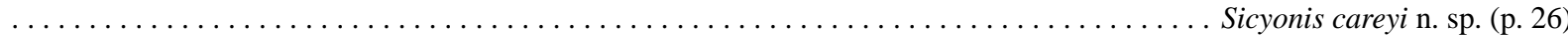


Oral disc lobed. Column smooth, divisible into scapus and capitulum. Acontia with microbasic $b$-mastigophores and microba-

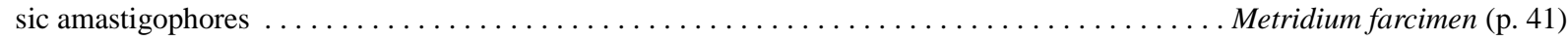

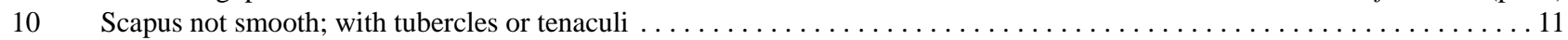



11 Scapus of intact animal black, rough due to cuticle-covered tentaculi; very short scapulus orangish. Column cannot shorten. Pedal disc attached to manganese nodule. Acontia small, difficult to find. . . . . . . . . . . . Bathyphellia australis (p. 31)

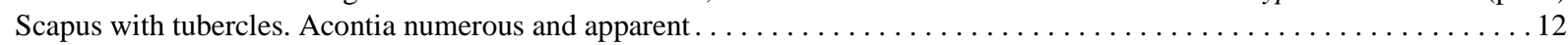

12 Tubercles pointed; arrayed in longitudinal rows. Tentacles more numerous than number of mesenteries at mid-column ......

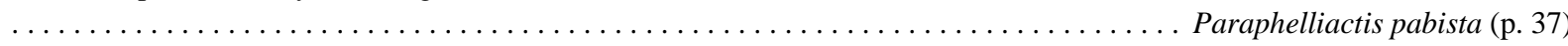
Tubercles flat; not arrayed in longitudinal rows. Same number of tentacles as mesenteries along column. .

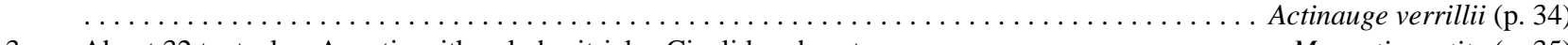

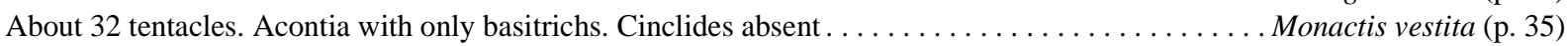
About 200 tentacles. Acontia with basitrichs and microbasic amastigophores. Cinclides present.

Sagartiogeton californicus (p. 43) 


\section{Order Corallimorpharia}

\section{Family Corallimorphidae Hertwig, 1882}

\section{Genus Corallimorphus Moseley, 1877}

Corallimorphus denhartogi Fautin, White, and Pearson, 2002

(Figures 1-2, Appendix 2)

No synonyms

Diagnosis. Column short and discoidal (Figure 1); oral disc to approximately $70 \mathrm{~mm}$ diameter; ectoderm sloughed off nearly all specimens. Mouth small (less than 1/3 oral disc diameter), ovoid; lips around mouth indistinct. Tentacles short and capitate, acrospheres typically broken off. Discal tentacles short, all about same size ( $2 \mathrm{~mm}$ long); marginal tentacles in three sizes (approximately 12 large, 12 medium, 24 small), to $8 \mathrm{~mm}$ long. Marginal:discal tentacles in approximately 2:1 ratio; about 72 total. Pedal disc slightly concave. For a detailed description of $C$. denhartogi, see Fautin et al. (2002).

Cnidae. Spirocysts, basitrichs, holotrichs, microbasic $p$-mastigophores, microbasic $b$-mastigophores.

Distribution. Corallimorphus denhartogi was originally described from California to Oregon at depths of 2,550 to 4,300 $\mathrm{m}$ (Fautin et al. 2002). All specimens we examined occur within the previously known range (Figure 2).

Material examined. See Appendix 2.

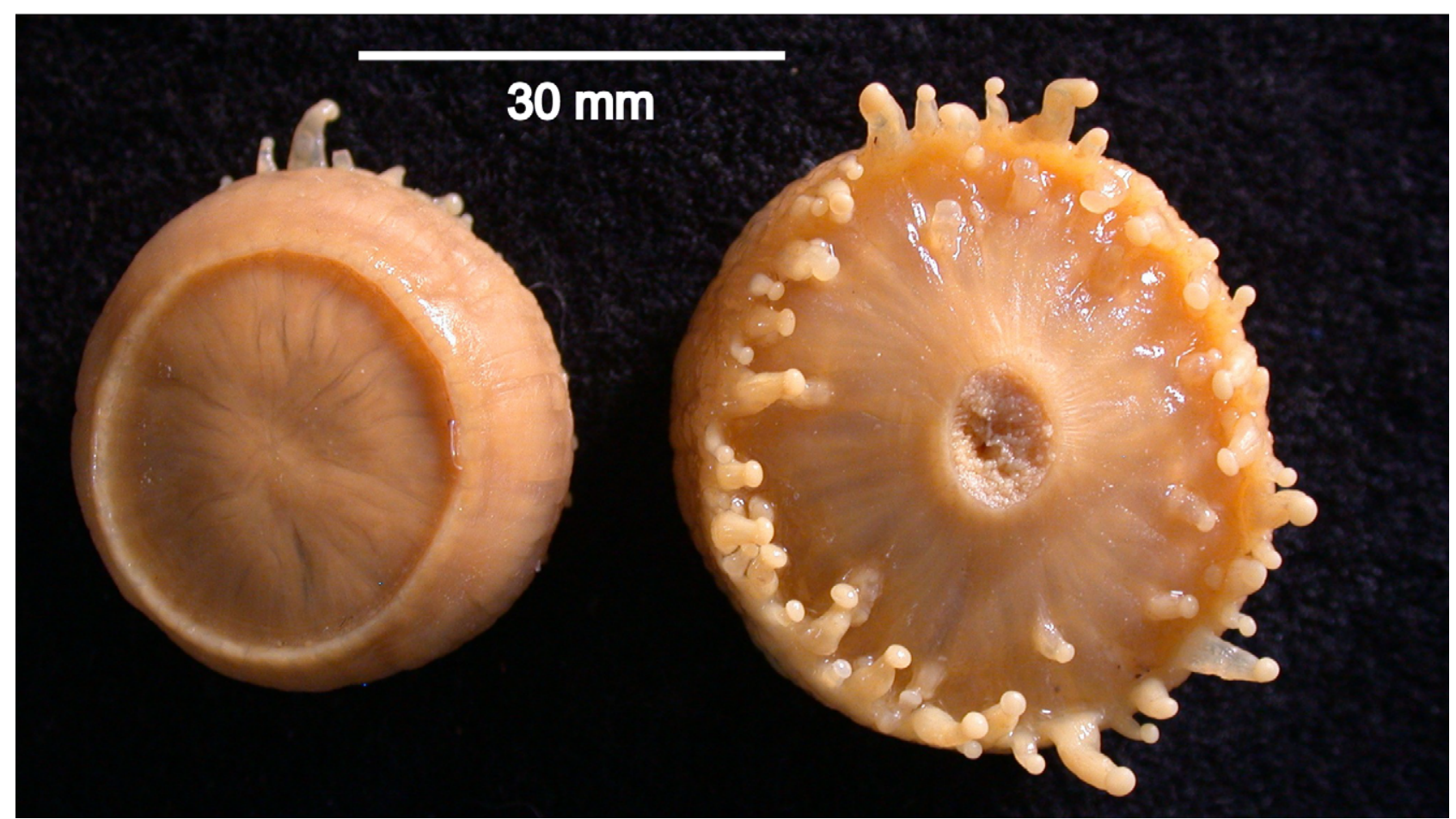

FIGURE 1. Specimens of Corallimorphus denhartogi (KUIZ 001554). 


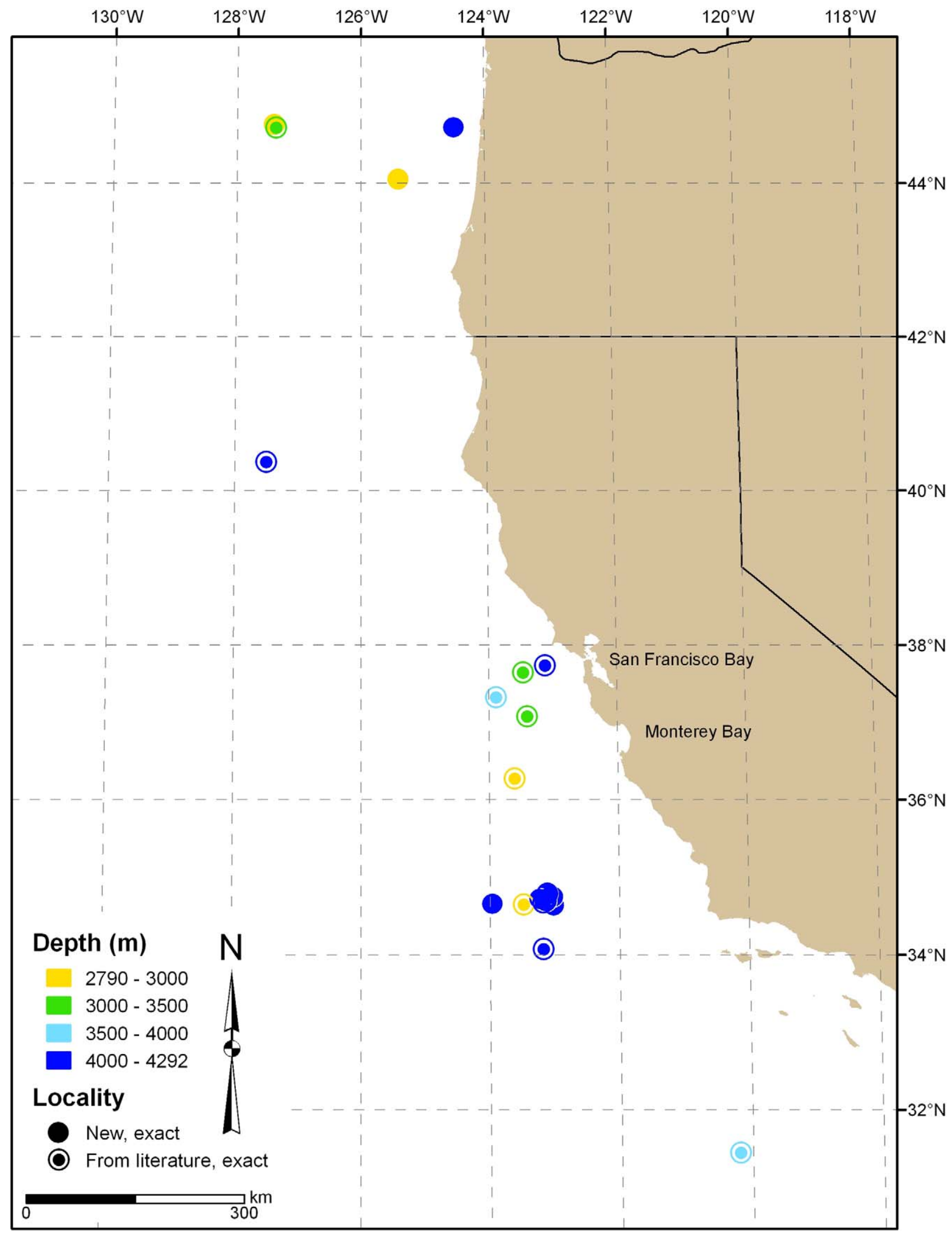

FIGURE 2. Distribution of Corallimorphus denhartogi from southern California to Oregon. 
Corallimorphus pilatus Fautin, White, and Pearson, 2002

(Figures 3-4, Appendix 3)

No synonyms

Diagnosis. Column cylindrical; oral and pedal discs about same diameter (to $35 \mathrm{~mm}$ ), column slightly shorter than diameter of discs (to $20 \mathrm{~mm}$ ). Sparse tan ectoderm may be attached to column; brown ectoderm may persist near base of tentacles. Oral disc with raised lips around slit mouth; with long, capitate tentacles (Figure 3). Marginal tentacles shorter than discal tentacles (about $15 \mathrm{~mm}$ ), in approximately 4:1 marginal:discal ratio; about 130 total. Pedal disc typically attached to stone or shell. For a detailed description of C. pilatus see Fautin et al. (2002).

Cnidae. Spirocysts, basitrichs, holotrichs, microbasic $p$-mastigophores, microbasic $b$-mastigophores.

Distribution. Corallimorphus pilatus was originally described from California to British Columbia at depths of 198 to $900 \mathrm{~m}$ (Fautin et al. 2002). Additional specimens we examined extend the range north to include south coastal Alaska (Figure 4) and down to 2,026 m.

Material examined. See Appendix 3.



FIGURE 3. Specimen of Corallimorphus pilatus (KUIZ 003256). 


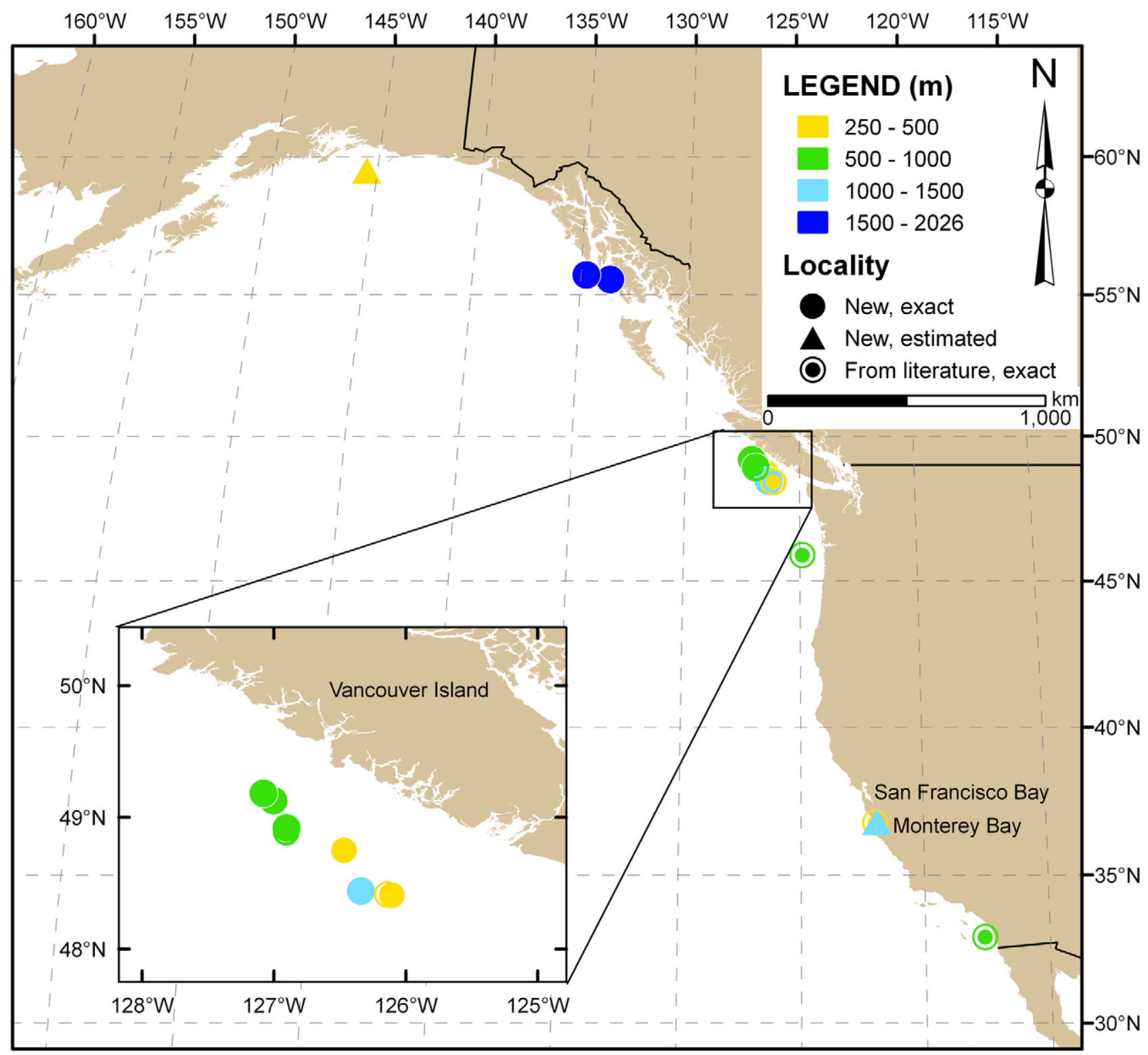

FIGURE 4. Distribution of Corallimorphus pilatus from California to the Gulf of Alaska.

\section{Order Actiniaria}

\section{Family Actiniidae Rafinesque, 1815}

\section{Genus Bolocera Gosse, 1860}

\section{Bolocera kensmithi n. sp.}

(Figures 5-8, Table 1, Appendix 4)

Body form and size. Column tan or pink, smooth, ectoderm typically slightly wrinkled. Column stiff but not thick (about $0.5 \mathrm{~mm}$ ); mesenterial insertions typically visible along entire length, most evident at limbus and margin. In some preserved specimens mesenteries protrude from proximal end of column or pedal disc (Figure 5).

Most animals contracted so margin partially covers insertion of tentacles. Column short (10-31 mm long), in most animals tapers from oral disc (8-41 $\mathrm{mm}$ diameter) to pedal disc (3-22 $\mathrm{mm}$ diameter); one specimen inside-out so mesenteries were exposed (Figure 5). 


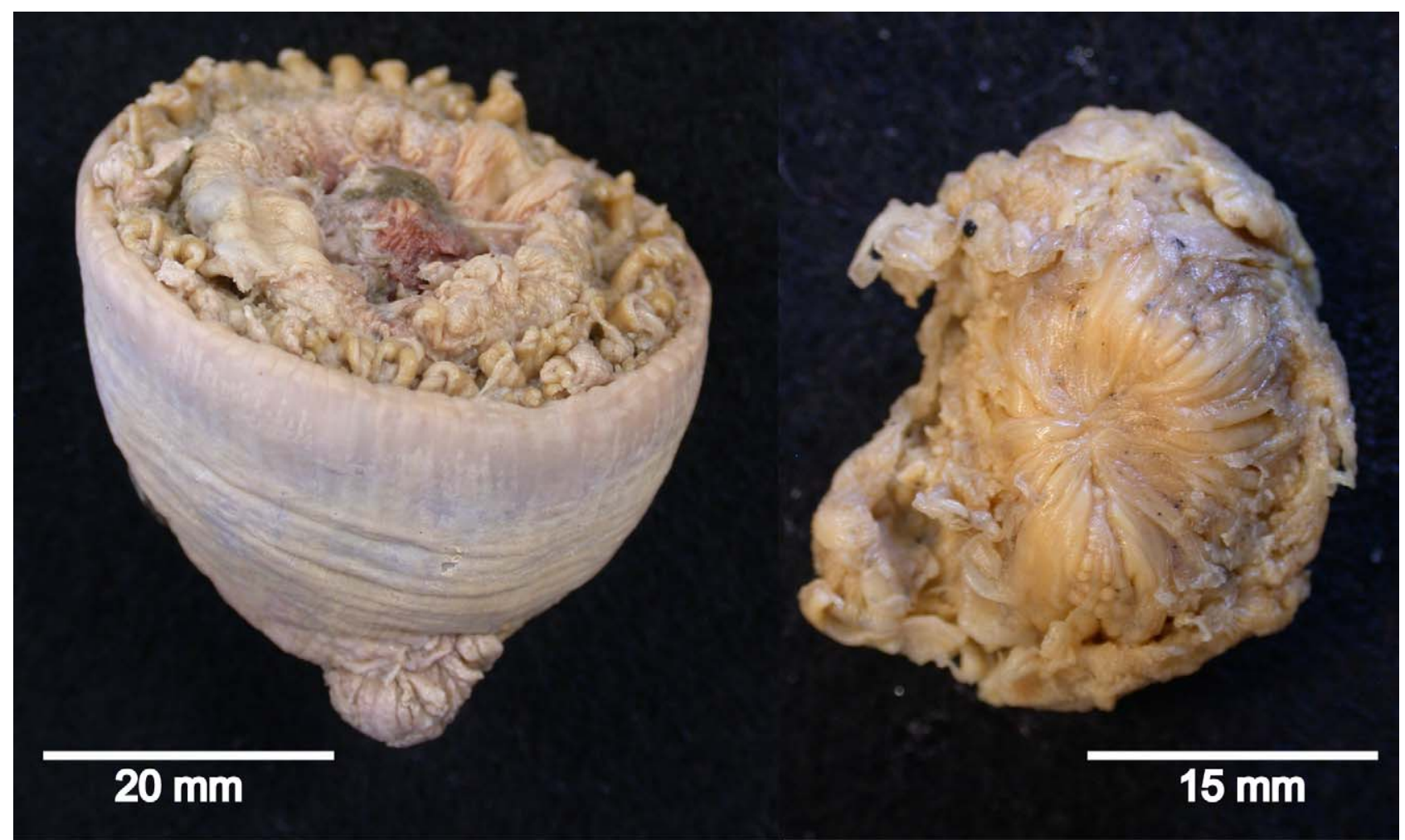

FIGURE 5. Specimens of Bolocera kensmithi n. sp. Holotype specimen lacking tentacles on left (KUIZ 003252); specimen lacking tentacles and turned inside-out on right (KUIZ 001518).

Tentacles deciduous (characteristic of genus): circumscribed endodermal sphincter muscle at base of each tentacle. All specimens devoid of tentacles.

Pedal disc. Tan to pink, wrinkled or smooth. Circular, slightly concave; about half diameter of oral disc.

Oral disc and tentacles. Oral disc tan to reddish-purple; smooth in poorly-preserved specimens, radially furrowed along mesenterial insertions in well-preserved specimens. In most specimens, oral disc torn, and mesenteries protrude through mouth. Mouth large (about 2/3 diameter of oral disc, opening to $18 \mathrm{~mm}$ ); radially furrowed, lips raised and very prominent when mouth not torn (to $5 \mathrm{~mm}$ wide and long). Two prominent, symmetrical, off-white siphonoglyphs apparent in specimens with intact oral disc.

Number and arrangement of tentacles inferred by pores (to about $2 \mathrm{~mm}$ diameter) on oral disc; small ridge typically surrounds each pore. To 72 pores, about 48 in most specimens, arrayed in three or four cycles; those of inner cycles communicate with endocoels, those of outermost cycle communicate with exocoels.

Internal anatomy. Actinopharynx tan to deep purple, longitudinally furrowed; protruded in most specimens, nearly same length as column. Each of two long symmetrical siphonoglyphs attached to pair of directive mesenteries.

Mesenteries thick and muscular, hexamerously arrayed in three cycles; typically more numerous at limbus than at margin (e.g. 56 vs. 48). Rare quaternary mesenteries occur in pairs between mesenteries of second and third cycles (i.e. 114433442244334411: bolded 4s represent position of quaternary mesenteries absent in most specimens examined). First to third cycle complete; youngest complete mesenteries reach actinopharynx only at distal end. Incomplete mesenteries lack filaments. Oral stomata large, marginal stomata small. Directives and some members of youngest cycle sterile; all other mesenteries fertile. Sexes separate; ova to about $1.5 \mathrm{~mm}$ diameter.

Retractor muscles strong and diffuse (Figure 6a); in some specimens may be lobed. Parietobasilar muscles with no pennons or short detached ones.

Diffuse endodermal marginal sphincter muscle poorly developed; lamellae short to moderately long (Figure $6 b)$. 

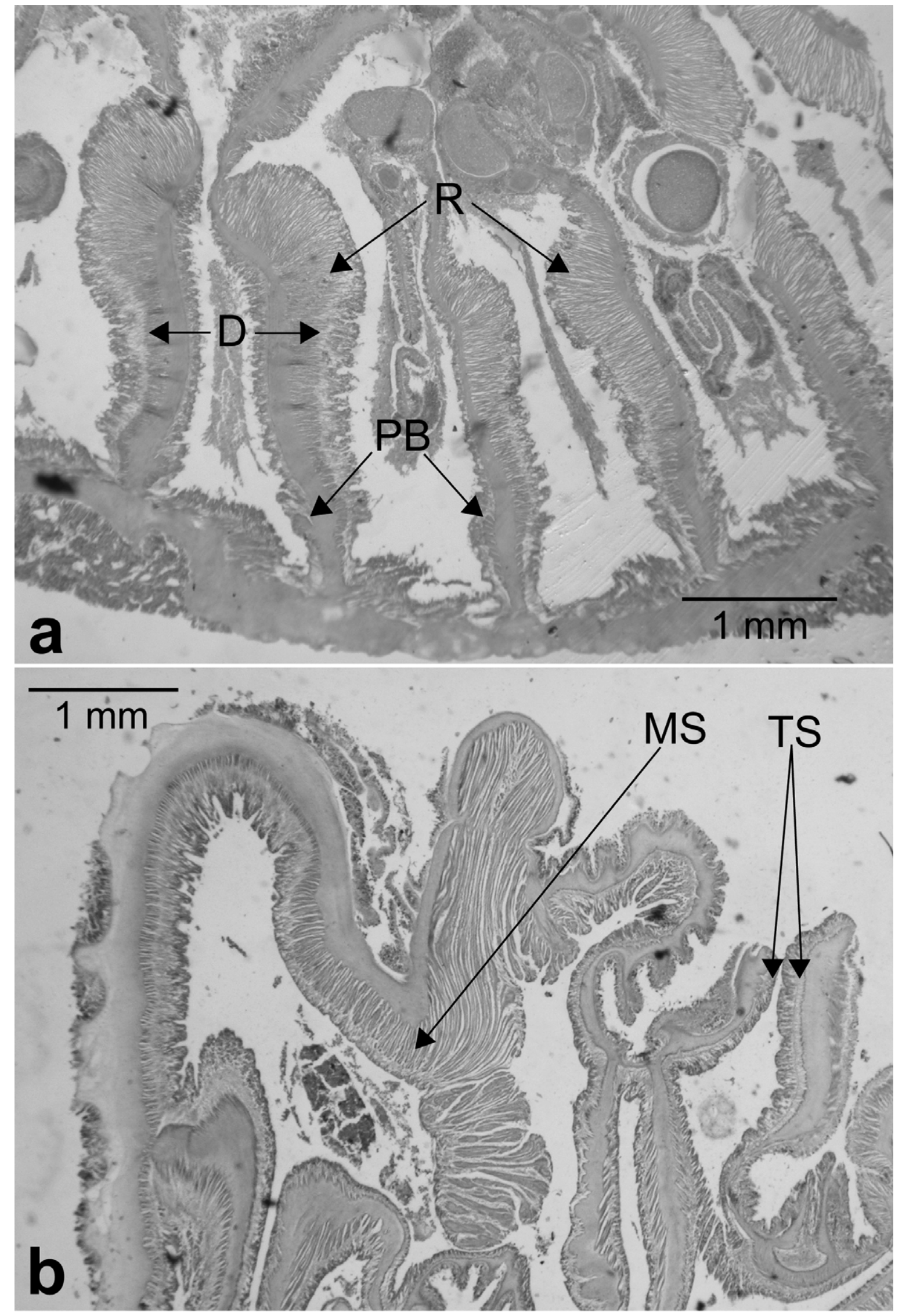

FIGURE 6. Bolocera kensmithi $\mathrm{n}$. sp. a. Cross section with directive mesenteries (D), diffuse retractor muscles (R), and parietobasilar muscles (PB); b. Longitudinal section with endodermal marginal sphincter muscle (MS) and endodermal tentacle sphincter muscle (TS). 
Cnidae. Basitrichs, microbasic p-mastigophores; presumably spirocysts are present in tentacles, but all specimens examined lacked tentacles. Sizes and distribution of cnidae given in Table 1; cnidae illustrated in Figure 7.

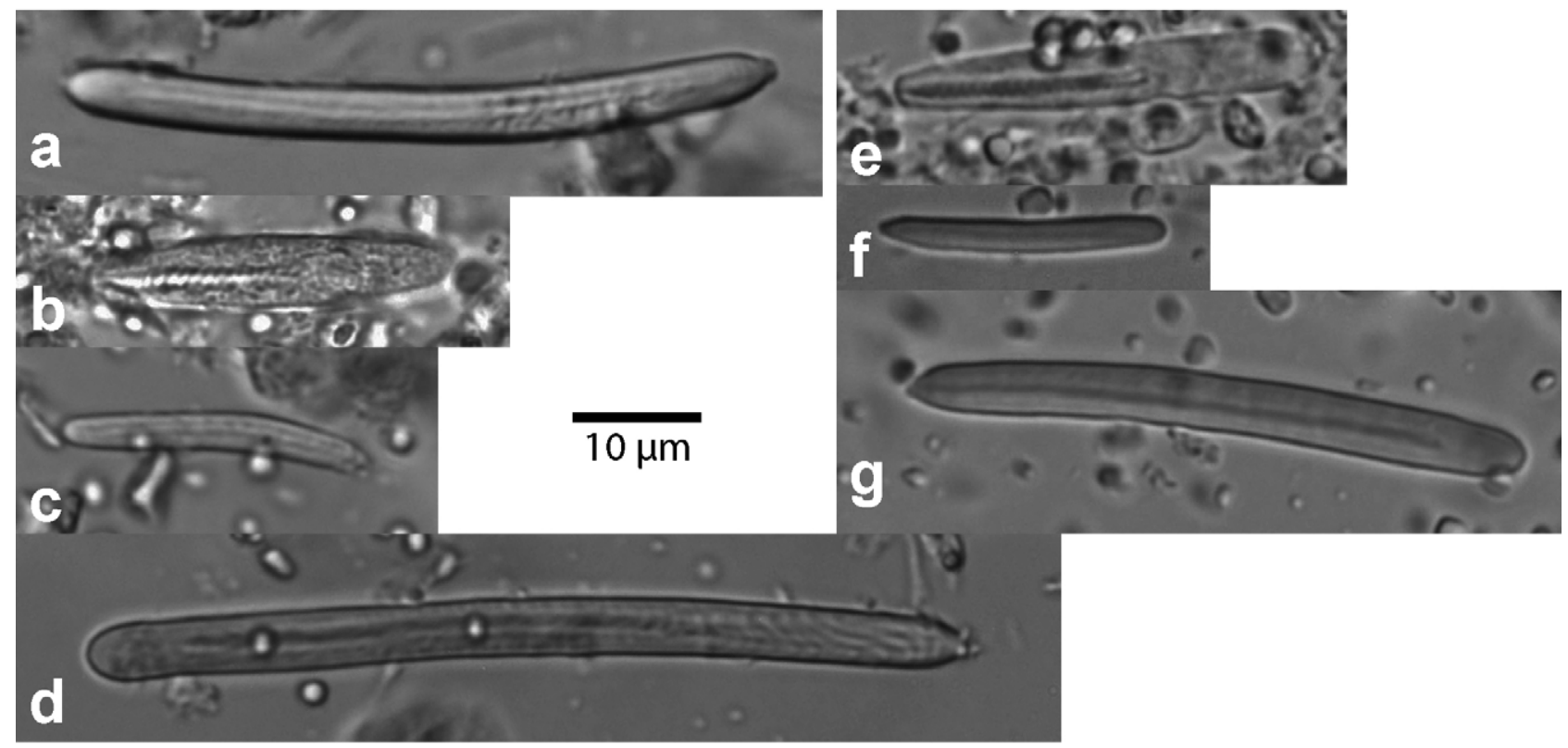

FIGURE 7. Cnidae of Bolocera kensmithi n. sp.; distribution and dimensions in Table 1. a. Basitrich; b. microbasic pmastigophore; c. basitrich; d. basitrich; e. microbasic $p$-mastigophore; f. basitrich; g. basitrich.

TABLE 1. Cnidae size and distribution of Bolocera kensmithi n. sp. All specimens lacked tentacles. * Sparse.

\begin{tabular}{llll}
\hline Tissue and Cnida Type & Length $\mathbf{x}$ Width $(\boldsymbol{\mu m})$ & $\mathbf{n}$ & $\mathbf{N}$ \\
\hline Actinopharynx & & & \\
Basitrichs (a) & $(49.0) 54.1-75.7 \times 4.0-5.1$ & 36 & $5 / 5$ \\
$\quad$ Microbasic $p$-mastigophores* (b) & $25.2-31.4 \times 4.6-5.6(6.0)$ & 13 & $3 / 5$ \\
Mesenterial Filaments & & & \\
Basitrichs* (c) & $21.2-28.7(35.4) \times 2.6-3.3$ & 38 & $6 / 6$ \\
Basitrichs (d) & $(57.1) 59.1-74.1 \times 3.9-5.2$ & 49 & $6 / 6$ \\
Microbasic p-mastigophores* (e) & $(25.4) 26.9-36.2(37.7) \times 4.0-5.4(5.9)$ & 48 & $6 / 6$ \\
Column & & & \\
Basitrichs (f) & $(18.0) 19.8-26.9(29.0) \times 2.3-3.2$ & 30 & $5 / 5$ \\
Basitrichs (g) & $36.1-50.8(53.1) \times 3.5-4.9$ & 41 & $5 / 5$ \\
\hline
\end{tabular}

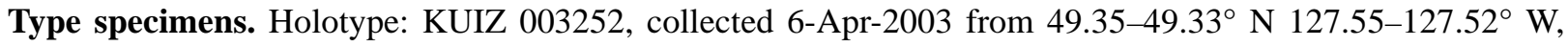
1,804-1,827 m. Column length $25 \mathrm{~mm}$, oral disc diameter $40 \mathrm{~mm}$, and pedal disc $22 \mathrm{~mm}$. Third cycle of mesenteries developed, fourth cycle partially developed with same number of tentacle pores.

Paratypes: CAS 184529, 4 specimens collected 5-Jun-1996 from $34.67^{\circ} \mathrm{N} 123.18^{\circ} \mathrm{W}, 4,100 \mathrm{~m}$; USNM 1149361, 1 specimen collected 14-Nov- 1995 from $34.70^{\circ} \mathrm{N} 123.03^{\circ} \mathrm{W}, 4,100 \mathrm{~m}$; KUIZ 001522, 1 specimen collected 29-Jan-1996 from $34.72^{\circ} \mathrm{N} 123.22^{\circ} \mathrm{W}, 4,100 \mathrm{~m}$; SBMNH 149659, 1 specimen collected 17-Oct-1992 from $34.77^{\circ} \mathrm{N} 123.13^{\circ} \mathrm{W}, 4,100 \mathrm{~m}$; RBCM 010-00573-001, 1 specimen collected 15-Apr-2003 from 49.71-49.71 $\mathrm{N} 127.95-127.96^{\circ} \mathrm{W}, 2,003-2,091 \mathrm{~m}$.

Etymology. Named in honor of Kenneth L. Smith, Jr., who collected specimens of this species, as well as many other deep-sea anemones, from Station M off the coast of California.

Distribution. Bolocera kensmithi n. sp. lives in the northeastern Pacific Ocean, and has been collected in trawls from at least $1,804 \mathrm{~m}$ to $4,100 \mathrm{~m}$ (Figure 8). 


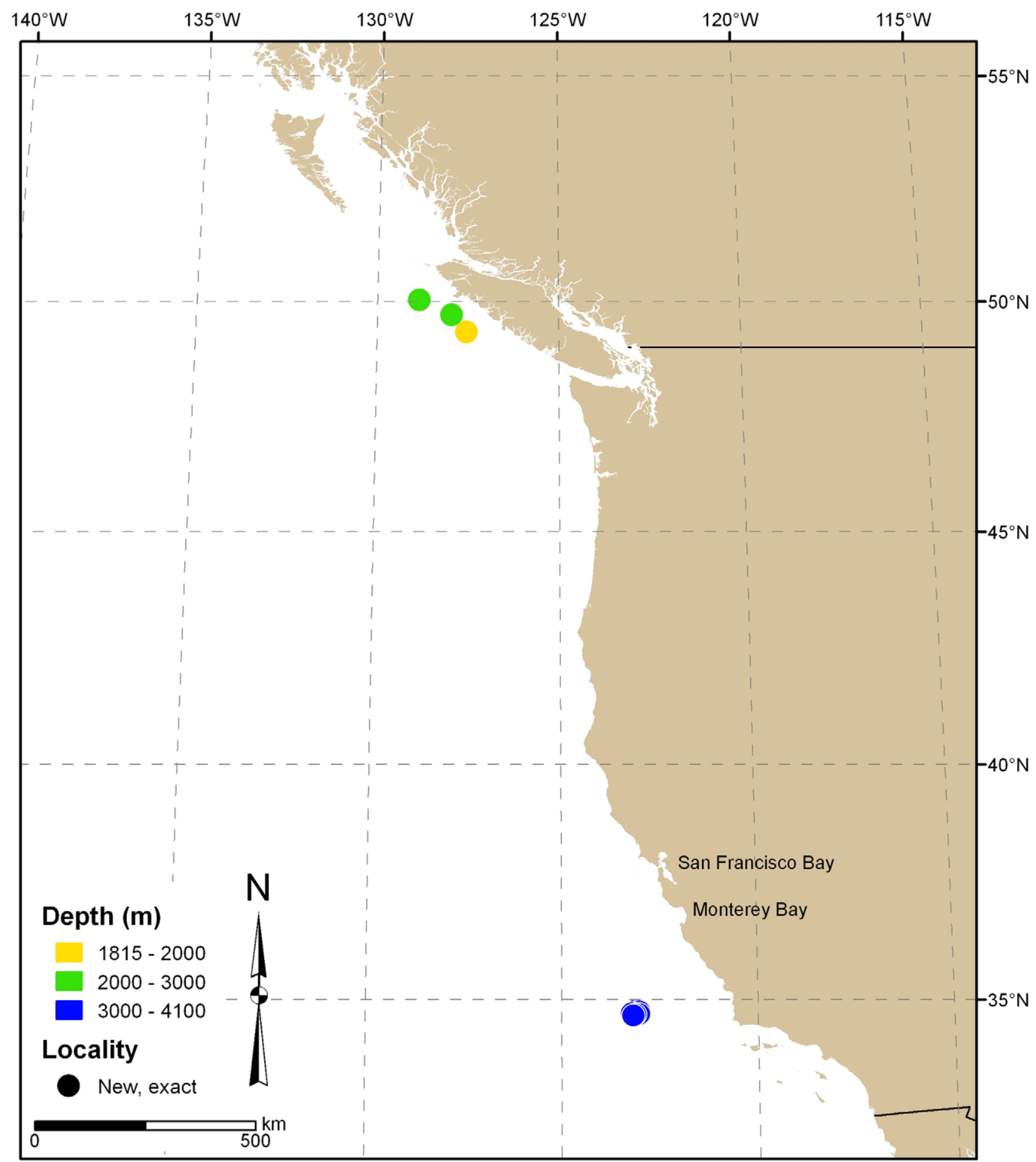

FIGURE 8. Distribution of Bolocera kensmithi n. sp. from California to British Columbia.

Material examined. See Appendix 4.

Differential diagnosis. The only other species of Bolocera known from the northeastern Pacific is B. pannosa McMurrich, 1893, which has a large, convex oral disc covered by about 400 tentacles, and an oral disc that conceals the short column, is easily separated from B. kensmithi n. sp. Bolocera kensmithi n. sp. can be distinguished from its congeners by its combination of: concave pedal disc; column that tapers from the widest part distally to the narrowest part proximally; about 48 tentacles arrayed in four cycles; 24 pairs of mesenteries arrayed in three cycles (plus occasionally a few pairs of a fourth cycle); directive mesenteries sterile; marginal stomata. 
Dichotomous key to species of Bolocera (except Bolocera maxima, described by Carlgren [1921] from off Greenland based solely on tentacles, and therefore distinguished by its nematocysts, for which we lack comparable data for B. kensmithi n. sp.).

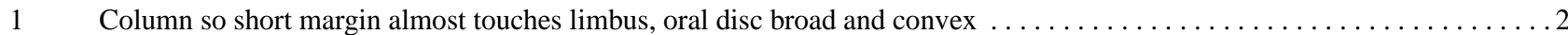
Column not short, either cylindrical or wider at distal than at proximal end, margin not near limbus $\ldots \ldots \ldots \ldots . \ldots 3$ About 400 flaccid slender tentacles to $37 \mathrm{~mm}$ long arrayed in seven cycles. Pedal disc oval $(70$ x $25 \mathrm{~mm}$ diameter in average specimen) and thin; mesenterial insertions visible. Northeastern Pacific Ocean . . . . . . . . . . B. pannosa McMurrich, 1893 About 150 blunt digitiform tentacles to $20 \mathrm{~mm}$ long scattered over oral disc. To five cycles of mesenteries; oral and marginal stomata present. Pedal disc circular, slightly larger diameter than proximal end of column. Two size classes of basitrichs in

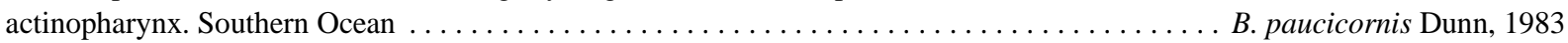
Marginal sphincter muscle well developed $\ldots \ldots \ldots \ldots \ldots \ldots \ldots \ldots \ldots \ldots \ldots \ldots \ldots \ldots \ldots \ldots \ldots \ldots \ldots \ldots$

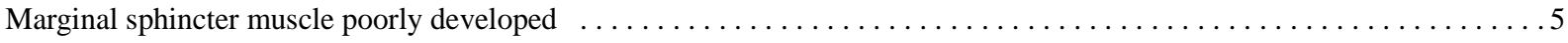

4 Column approximately twice as long as diameter of oral and pedal disc in preserved specimens; tentacles arrayed in four


Column thin, same length as diameter of oral disc in preservation. About 200 long, conical, and longitudinally furrowed tentacles arrayed in five or six cycles. Northern Atlantic Ocean . . . . . . . . . . . . . . . . . B. tuediae (Johnston, 1832)

$5 \quad$ All mesenteries fertile except for directives and some of youngest cycle $\ldots \ldots \ldots \ldots \ldots \ldots \ldots \ldots \ldots \ldots \ldots \ldots \ldots \ldots \ldots \ldots$

- Mesenteries of first cycle, and some of second cycle sterile; 96 pairs of mesenteries total, 48 pairs complete. About 180

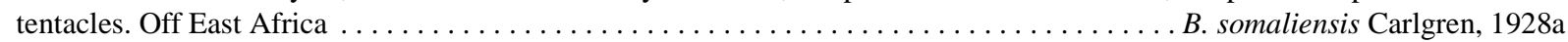

6 Mesenteries lack oral and marginal stomata. To five cycles of thin mesenteries equally developed along column; parietobasilar muscles with large detached pennons. Tentacles (to about 100) arrayed in as many as seven cycles. Basitrichs of mesenterial filaments to $64 \mu \mathrm{m}$ long, one size class of basitrichs in column. South of $30^{\circ} \mathrm{S} \ldots \ldots \ldots \ldots$. . . B. kerguelensis Studer, 1879 Mesenteries possess oral and marginal stomata. 24 pairs of thick mesenteries arrayed in three cycles (plus rarely a few pairs of a fourth cycle), develop from proximal end; parietobasilar muscles with small detached pennons or without pennons. About 48 tentacle pores (correspond to number of tentacles in life) arrayed in four cycles near margin. Pedal disc circular. Basitrichs of mesenterial filaments to $73 \mu \mathrm{m}$ long; two size classes of basitrichs in column. Northeastern Pacific Ocean . . . . . . . . . .

B. kensmithi $\mathrm{n}$. sp.

\section{Family Actinoscyphiidae Stephenson, 1920}

\section{Genus Actinoscyphia Stephenson, 1920}

\section{Actinoscyphia groendyki n. sp.}

(Figures 9-12, Table 2, Appendix 5)

Body form and size. Exposed mesoglea of specimens light grey to tan; some with dingy grey ectoderm sloughing off. Mesoglea thick throughout column, to $8 \mathrm{~mm}$ at proximal end of specimen $33 \mathrm{~mm}$ long. Column smooth and stiff; tapers from distal end. Margin contracted so column covers most tentacles. Oral disc in nearly all specimens examined folded in half perpendicular to long axis, giving animals Venus flytrap posture (Figure 9). Pedal disc elongate; long axis in same direction as long axis of oral disc.

Column 9-42 mm long; long axis of pedal disc approximately same length as long axis of oral disc, typically longer than column.

Pedal disc. Pedal disc tan or light brown; most specimens with metallic brown chitinous material, inferred to be secreted by animal, closely associated with pedal disc. Most elongate, from 4 to $134 \mathrm{~mm}$; in large specimens pedal disc wrapped around or appears to have been wrapped around cylindrical object such as worm tube or group of sponge spicules (Figure 9). In small specimens (about $10 \mathrm{~mm}$ column length) pedal disc small, concave, holds bolus of mud.

Oral disc and tentacles. Oral disc tan or salmon, oval, radially furrowed along mesenterial insertion; folds in half, hiding tentacles.

Mouth circular, approximately 1/4 oral disc diameter; with raised lips. Slightly darker than oral disc, or deep purple; tan or light brown radial stripe typically at oral end of each siphonoglyph.

Tentacles slightly lighter in color than oral disc, smooth; tapered (1-4 mm at widest part of base to $0.1-1 \mathrm{~mm}$ at tip), 1-12 mm long, all thickened aborally with mesoglea. Most specimens with 120-149 tentacles (one small specimen possessed only 90) arrayed in two cycles near margin; exocoelic tentacles short and outermost, endocoelic tentacles long and innermost. 




FIGURE 9. Specimens of Actinoscyphia groendyki n. sp. Specimen attached to sponge spicules on left (SBMNH 522590); specimen with tentacles visible on right (SBMNH 144408).

Internal anatomy. Actinopharynx deep purple, very long, longitudinally sulcate. Each of two symmetrical siphonoglyphs attached to pair of directive mesenteries; directive plane perpendicular to long axis of oral and pedal discs.

Mesenteries thin, typically arrayed in five cycles (specimens about $10 \mathrm{~mm}$ column length possess only four cycles); develop distally. All mesenteries with filaments; those of only first cycle complete, stomata absent. Mesenteries of first cycle sterile; mesenteries of second cycle rarely fertile; all younger mesenteries may be fertile. Mesenteries of youngest cycle regularly arrayed; all pairs do not develop simultaneously: one pair flanking a pair of preceding cycle develops on side nearer older pair of mesenteries (i.e. 115544553355445522, bolded 5s represent where late-developing pairs will presumably appear, although absent in specimens examined) (Figure 10a). Pattern holds for fourth cycle mesenteries; in one specimen both pairs flanked those of third cycle in some places, and only one pair had developed in others. Retractor muscles very weak and short; parietobasilar muscles weak.

Mesogleal marginal sphincter muscle weak, moderately long (to approximately 1/3 column length), with many alveoli, slightly striated transversely in some specimens (Figure 10b), or distinctively striated only near proximal end. Situated in middle of mesoglea distally where broadest, occupies approximately half mesoglea width; tapers and approaches endoderm proximally. Alveoli pigmented, giving sphincter muscle tan color. Distal alveoli small and may be spaced apart or clumped; proximal alveoli larger.

Longitudinal muscles of tentacles mostly ectodermal with little mesogleal involvement, circular muscles endodermal (Figure 10c).

Cnidae. Gracile and robust spirocysts, basitrichs, holotrichs, microbasic p-mastigophores. Sizes and distribution of cnidae given in Table 2; cnidae illustrated in Figure 11.

Type specimens. Holotype: SBMNH 149661, collected 19-Feb-1971 from $44.99^{\circ} \mathrm{N} 126.66^{\circ} \mathrm{W}, 2,770 \mathrm{~m}$. Column length $34 \mathrm{~mm}$, oral disc folded $30 \times 45 \mathrm{~mm}$, and elongate pedal disc $40 \mathrm{~mm}$. Fourth cycle of mesenteries developed, fifth cycle partially developed; 149 tentacles.

Paratypes: SBMNH 149662, 1 specimen, collected 19-Feb-1971 from $44.99^{\circ} \mathrm{N} 126.66^{\circ} \mathrm{W}, 2,770 \mathrm{~m}$; KUIZ 003350, 1 specimen, collected 19-Feb-1971 from $44.99^{\circ} \mathrm{N} 126.66^{\circ} \mathrm{W}, 2,770 \mathrm{~m}$; KUIZ 003351, 1 specimen,

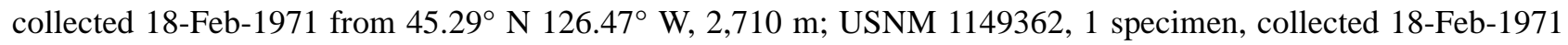
from $45.29^{\circ} \mathrm{N} 126.47^{\circ} \mathrm{W}, 2,710 \mathrm{~m}$; CAS 184531,1 specimen, collected 18 -Feb-1971 from $45.29^{\circ} \mathrm{N} 126.47^{\circ} \mathrm{W}$, 2,710 m; RBCM 010-00571-001, 1 specimen, collected 18-Feb-1971 from $45.29^{\circ} \mathrm{N} 126.47^{\circ} \mathrm{W}, 2,710 \mathrm{~m}$.

Etymology. Named in honor of Eash-Loucks' late grandfather, James Groendyk.

Distribution. Actinoscyphia groendyki n. sp. occurs in both the Southern and northeastern Pacific oceans and has been collected from depths of at least 636 to 3,819 m (Figure 12). 




FIGURE 10. Actinoscyphia groendyki $\mathrm{n}$. sp. a. Mesenteries of cycles $2-5$ with diffuse retractor muscles (R); b. distal portion of mesogleal sphincter muscle (for illustration of variation of sphincter muscles see Fautin [1984]) (S); c. cross section of tentacle with endodermal circular musculature $(\mathrm{C})$ and ectodermal longitudinal musculature with little mesogleal involvement (L).

Taxonomic remarks. We re-examined some of the 18 specimens from the Southern Ocean that Fautin (1984) had identified as Actinoscyphia plebeia (McMurrich, 1893). Features of specimens from the northeastern Pacific conform to what she reported except that 1) the microbasic $p$-mastigophores of the actinopharynx and the large basitrichs of the mesenterial filaments are smaller, and 2) mesenteries of the first cycle are always sterile whereas Fautin reported that only the directives and some mesenteries of the youngest cycle are sterile.

In the actinopharynx of specimens Fautin (1984) examined, we found small microbasic $p$-mastigophores (the smallest was $26.1 \times 4.0 \mu \mathrm{m}$ ), which fall within the same size range as those of specimens of A. groendyki $\mathrm{n}$. sp. Therefore, the only difference we found between specimens from the northeastern Pacific and Southern oceans was the size of large basitrichs in the mesenterial filaments, whose lengths overlaps by $1 \mu \mathrm{m}$. However, these nematocysts were not found in all specimens from the Southern Ocean, so they may be contaminants from the actinopharynx. We conclude that the specimens from the northeastern Pacific, as well as those examined by Fautin (1984), constitute a single species. In specimens from both localities, all mesenteries of the first cycle were sterile, as were those of the second cycle in most specimens. Thus these specimens clearly fall within the original diagnosis of Actinoscyphia by Stephenson (1920), which includes the first cycle of mesenteries being complete and sterile. 
Some features of the specimens we examined from the northeastern Pacific and those identified by Fautin (1984) as A. plebeia differ from those of Actinoscyphia plebeia as originally described by McMurrich (1893); therefore, we also examined the holotype of A. plebeia (USNM 17789).

USNM 17789 has 235 tentacles (a small portion of the margin, about 1/15, including tentacles was removed). However, McMurrich (1893) described the species as having only 96 tentacles. The number of tentacles we observed corresponds to the number of mesenteries in the specimen, because the fifth cycle was fully developed and some members of the sixth cycle of mesenteries were observed.

The number of tentacles and mesenteries of the holotype of A. plebeia distinguish that species from the northeastern Pacific specimens of Actinoscyphia and those reported by Fautin (1984). Additionally, the new species is distinguished from A. plebeia by the length and shape of the sphincter muscle (short and distinctly transversely striated throughout its entire length in A. plebeia), thickness of the mesoglea (much thinner in $A$. plebeia), oral stomata in A. plebeia, and cnidae (most notably the lack of holotrichs in the tentacles of A. plebeia, although this may be due to the condition of the specimen) (Table 2) (see Dichotomous key of Actinoscyphia).

Because Actinoscyphia groendyki n. sp. occurs in both the Southern and northeastern Pacific Oceans, we consider it likely that Actinoscyphia groendyki n. sp. occurs in the Southeastern Pacific Ocean as well. This also means that the analysis of Rodríguez et al. (2007) for A. plebeia must be reconsidered.

Material examined. See Appendix 5.

Differential diagnosis. Actinoscyphia groendyki n. sp. can be distinguished from its congeners by its combination of: elongate pedal disc; oval oral disc; to about 150 tentacles that are thickened aborally; five cycles of mesenteries (to 144 mesenteries at limbus), of which six pairs are complete and the first and typically the second cycle are sterile; absence of stomata; moderately long mesogleal marginal sphincter muscle with pigmented alveoli.
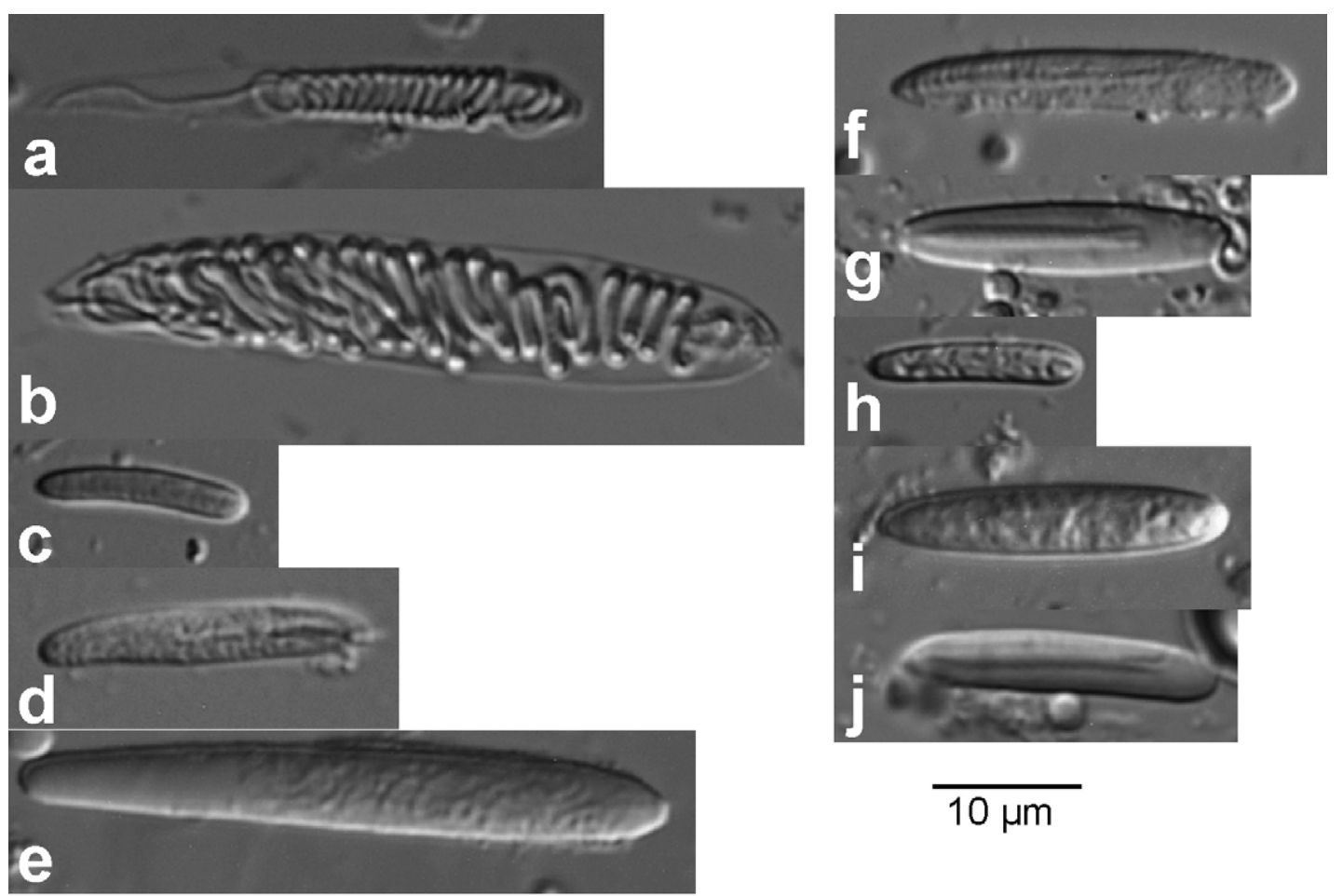

FIGURE 11. Cnidae of Actinoscyphia groendyki n. sp.; distribution and dimensions in Table 2. a. Gracile spirocyst; b. robust spirocyst; c. basitrich; d. basitrich; e. holotrich; f. basitrich; g. microbasic p-mastigophore; h. basitrich; i. basitrich; j. microbasic $p$-mastigophore. 


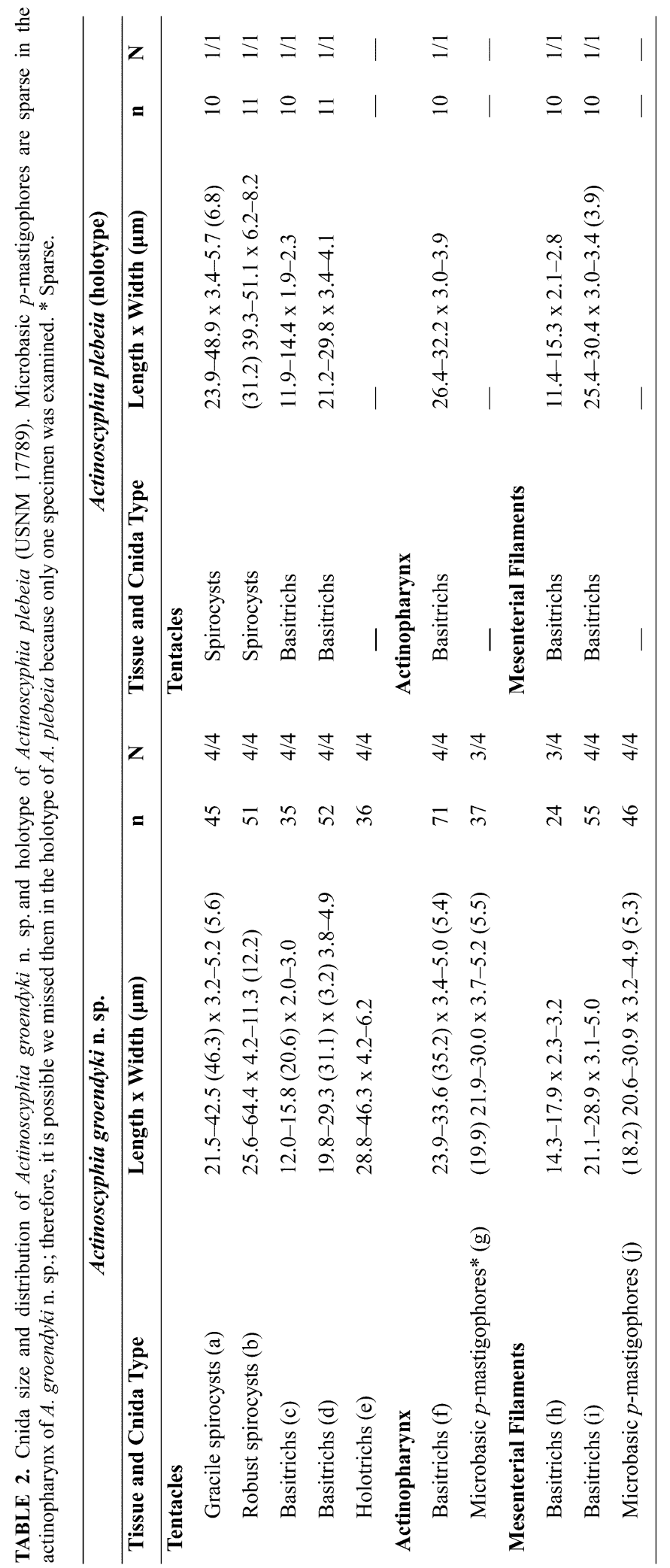




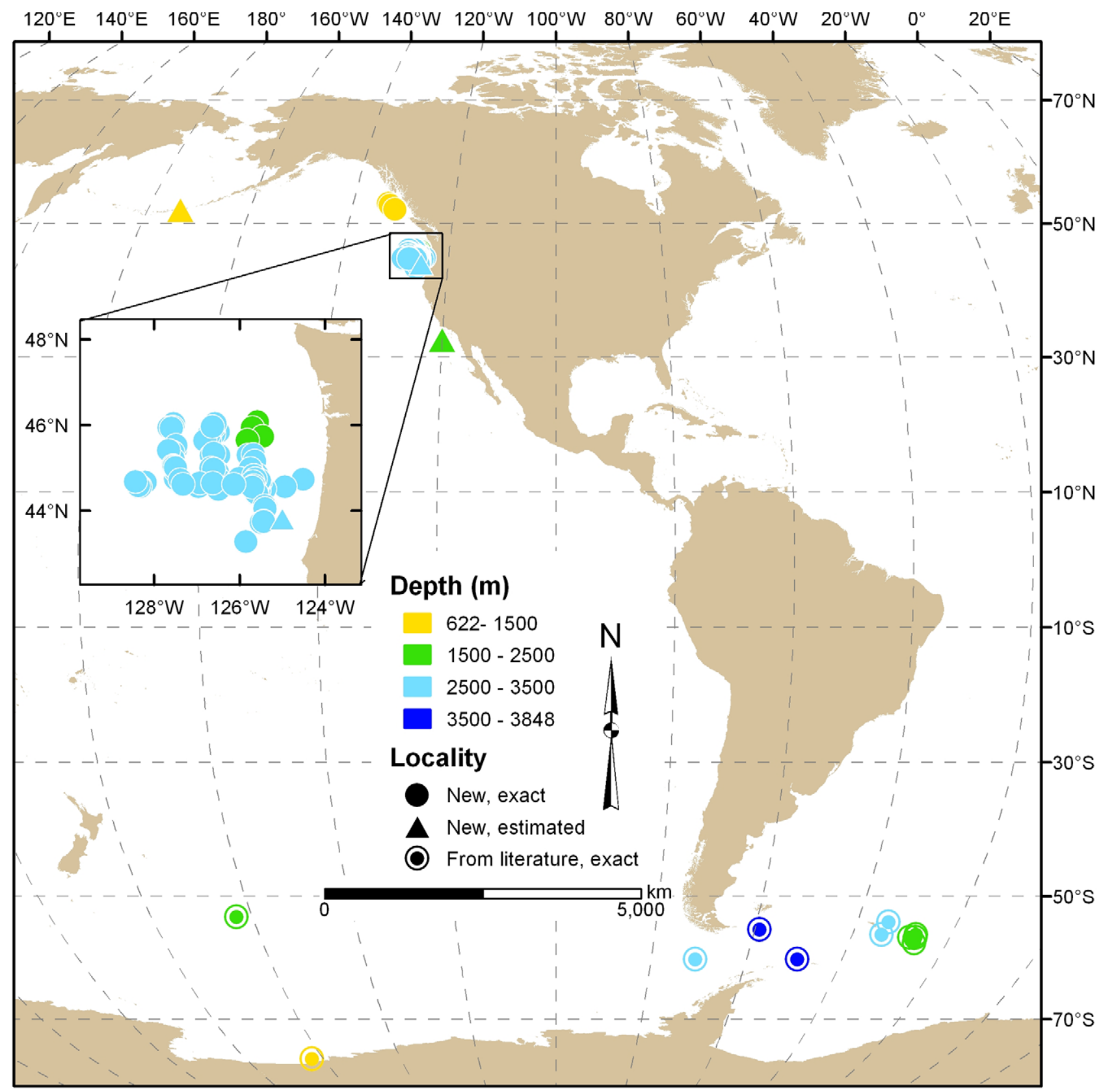

FIGURE 12. Distribution of Actinoscyphia groendyki n. sp. from the Southern and northeastern Pacific Ocean.

\section{Dichotomous key of Actinoscyphia.}

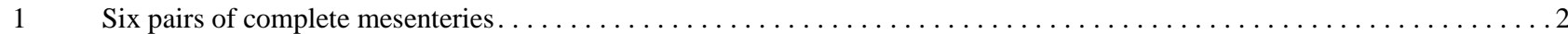
More than six pairs of mesenteries complete, more than 50 pairs of mesenteries total. Edges of oral disc undulate or folded on itself, pedal disc much smaller than oral disc; attached to dead branches of Lophelia Milne-Edwards \& Haime, 1849. North Atlantic Ocean. . . . . . . . . . . . . . . . . . . . . . . . . . . . . . . . . . . . . . A. verrilli (Gravier, 1918)

2 Alveoli of marginal sphincter muscle pigmented ...

Alveoli of marginal sphincter muscle lack pigmentation; oral disc slightly oval. Tentacles very long and thin (to about $50 \mathrm{~mm}$ long), thickened aborally at base. To five cycles of mesenteries. North Atlantic Ocean . . . . . . . . A. saginata (Verrill, 1882)

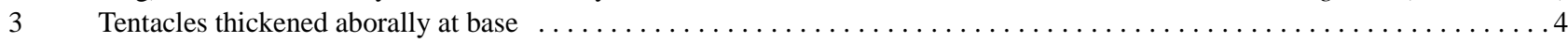

- Tentacles lacking aboral thickenings, short and slender, to 275 total; tentacles, oral disc, actinopharynx, and all endoderm except that of filaments dark red/purple. To seven cycles of mesenteries, oral stomata present. Pedal disc small and concave, holds sediment and mucus. North Atlantic Ocean . . . . . . . . . . . . . . . . . . . A. aurelia (Stephenson, 1918)

$4 \quad$ Mesoglea thickest proximally (about $7 \mathrm{~mm}$ ) and thinnest mid-column (about $1 \mathrm{~mm}$ ). Mesogleal marginal sphincter muscle very short (less than $1 / 10$ column length) and distinctly transversely striated throughout; under low magnification muscles look 
like a single column of horizontally-oriented ovals stacked on top of each other. Oral disc flat and circular, may fold on itself; to about 250 tentacles. To six cycles of mesenteries; those of first and second cycles sterile. Oral stomata present. Holotrichs of tentacles absent (Table 2). Southeastern Pacific Ocean . . . . . . . . . . . . . . . . . . . . . . A. plebeia (McMurrich, 1893) Mesoglea thick throughout column, to about $8 \mathrm{~mm}$. Mesogleal marginal sphincter muscle about $1 / 3$ column length; muscle with small alveoli, may be transversely striated near the proximal end. Oral disc oval, typically folded in half; to about 150 tentacles. To five cycles of mesenteries; those of first cycle and often second cycle sterile. Lack stomata. Holotrichs in tentacles (Table 2). Southern Ocean and northeastern Pacific Ocean . . . . . . . . . . . . . . . . . A. groendyki n. sp.

\section{Family Actinostolidae Carlgren, 1932}

\section{Genus Anthosactis Danielssen, 1890}

\section{Anthosactis nomados White, Wakefield Pagels, and Fautin, 1999}

(Figures 13-14, Appendix 6)

No synonyms

Diagnosis. Column light tan to white, very flat; to $65 \mathrm{~mm}$ diameter. Individuals typically attached to shells of scaphopod Fissidentalium actiniophorum Shimek, 1997 (Figure 13). Animals not attached to shells show evidence of once having been. Margin contracted so oral disc not visible. To 48 tentacles that taper to approximately $5 \mathrm{~mm}$. Three cycles of mesenteries, first two complete; lack acontia. For a detailed description of A. nomados, see White et al. (1999).

Cnidae. Spirocysts, basitrichs, microbasic $p$-mastigophores, microbasic $b$-mastigophores.

Distribution. Anthosactis nomados was originally described from the northeastern Pacific off California and Oregon at 3,700-4,100 m (White et al. 1999). We examined additional specimens collected off California and Oregon from 530 to $4,325 \mathrm{~m}$ (Figure 14).

Material examined. See Appendix 6.

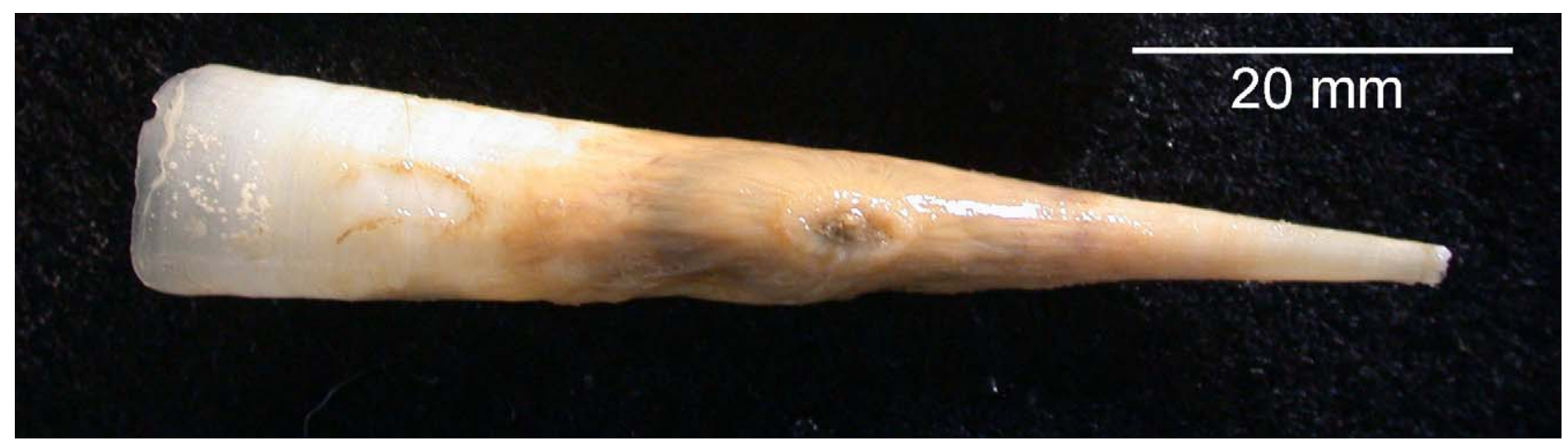

FIGURE 13. Specimen of Anthosactis nomados attached to shell of Fissidentalium actiniophorum (KUIZ 001559). 


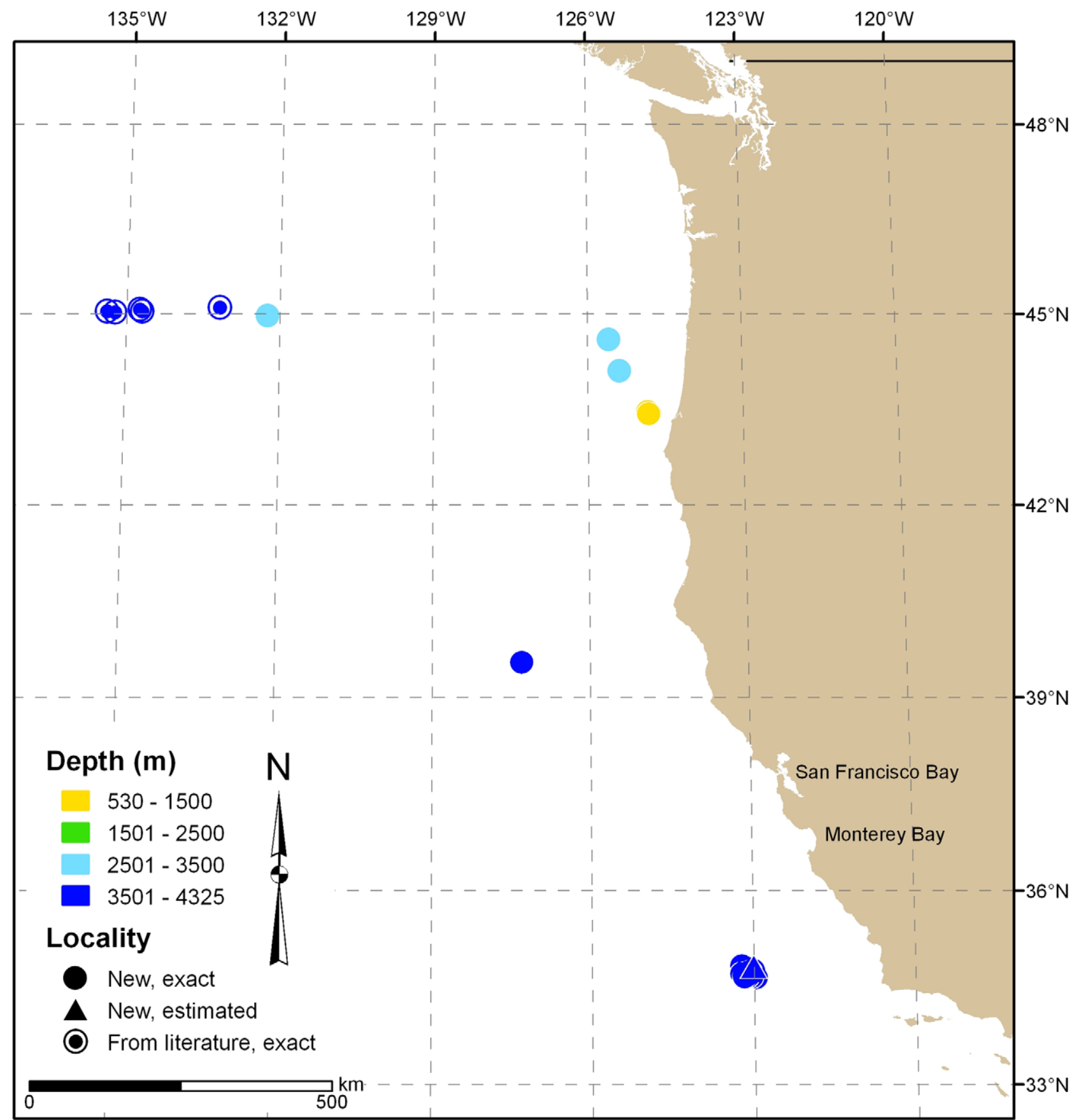

FIGURE 14. Distribution of Anthosactis nomados from California to Oregon.

\section{Genus Actinostola Verrill, 1883}

Actinostola faeculenta (McMurrich, 1893)

(Figures 15-17, Table 3, Appendix 7)

Synonyms

Cymbactis faeculenta: McMurrich (1893)

Paractinostola faeculenta: Carlgren (1949)

Diagnosis. Specimens typically lack ectoderm, exposing purple to white mesoglea (Figure 15). Column vasiform, with scattered, lumpy thickenings entire length; small specimens slightly translucent; brownish ectoderm may 


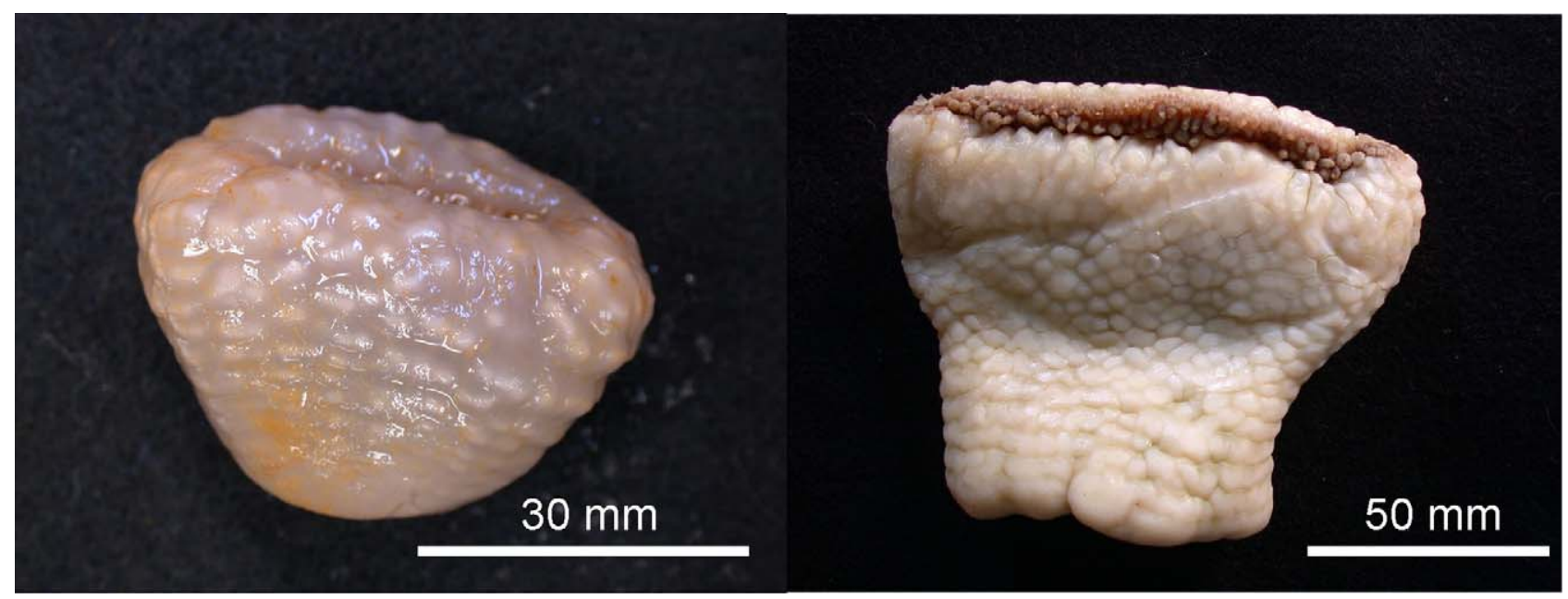

FIGURE 15. Specimens of Actinostola faeculenta. Small specimen on left (KUIZ 003301); large specimen on right (KUIZ 001459).

persist in crevices between thickenings. In smaller specimens thickenings more or less circular, in larger ones thickenings toward distal end elongated and tapered, resembling drips of viscous fluid; those near margin of contracted individual may be digitiform. Oral and pedal discs concave; pedal disc may be leathery. Column varies from about $15 \mathrm{~mm}$ wide and long to more than $200 \mathrm{~mm}$ wide and $150 \mathrm{~mm}$ long. Three to five cycles of mesenteries at mid-column; to three cycles of mesenteries complete (third cycle complete only distally). Mesenteries of first two cycles sterile, those of third to fifth cycle may be fertile. Additional small, thin mesenteries at only extreme proximal end, so numerous could not be counted. Number of mesenteries inferred to be equal to number of tentacles, which may exceed 200. Oral disc and tentacles typically solid tan (color of ectoderm remaining in crevices of column). Marginal tentacles very short, tightly packed; discal tentacles longer, pointed, may have shallow longitudinal furrows, and dispersed over marginal half of oral disc. For detailed information on $A$. faeculenta, see McMurrich (1893) and Carlgren (1934b).

Cnidae. Gracile and robust spirocysts, basitrichs, microbasic $p$-mastigophores, and microbasic $b$ mastigophores. Sizes and distribution of cnidae given in Table 3; cnidae illustrated in Figure 16.

Distribution. Actinostola faeculenta was described from six specimens collected north of the Channel Islands, California, USA at $757 \mathrm{~m}$ (McMurrich 1893). We examined additional specimens from southern California, north to British Columbia, and west to Japan from depths of 82 to 2,265 m (Figure 17).

Taxonomic remarks. This is among the largest and most massive, as well as one of the most distinctive, sea anemones in the deep northeastern Pacific.

Specimens of A. faeculenta we examined agreed with both McMurrich (1893) and Carlgren (1934b). The large specimens have more than 200 tentacles. The type specimens have about 150, which is similar to the number in smaller specimens we examined; therefore, it appears that number of tentacles (and, by inference, mesenteries) increases with size.

Despite how conspicuous the species is, cnidae size and distribution in specimens of Actinostola faeculenta had not previously been reported so we report them here (Table 3 ).

McMurrich (1893) could not find gametogenic tissue in the type specimens of Cymbactis faeculenta, so fertility pattern was not part of the generic definition. Although Carlgren (1934b) was also unable to detect gametogenic tissue in the type specimens, he moved the species from Cymbactis to Paractinostola (Carlgren, 1928a), a genus he had established (Carlgren 1928a) for P. bulbosa (Carlgren, 1928a) and P. capensis (Carlgren, 1928a), based on a more or less strongly lobed oral disc and fewer mesenteries at the base than tentacles. In his catalog to sea anemones of the world, Carlgren (1949) questionably also placed Cymbactis faeculenta in Paractinostola. Should the three species belong in a single genus, it would be termed Cymbactis, the older name [no other species have been attributed to Paractinostola; the combination Paractinostola ingolfi, found in Fautin and Barber (1999), is a lapsus for Parasicyonis ingolfi Carlgren, 1942: Fautin 2011]. 


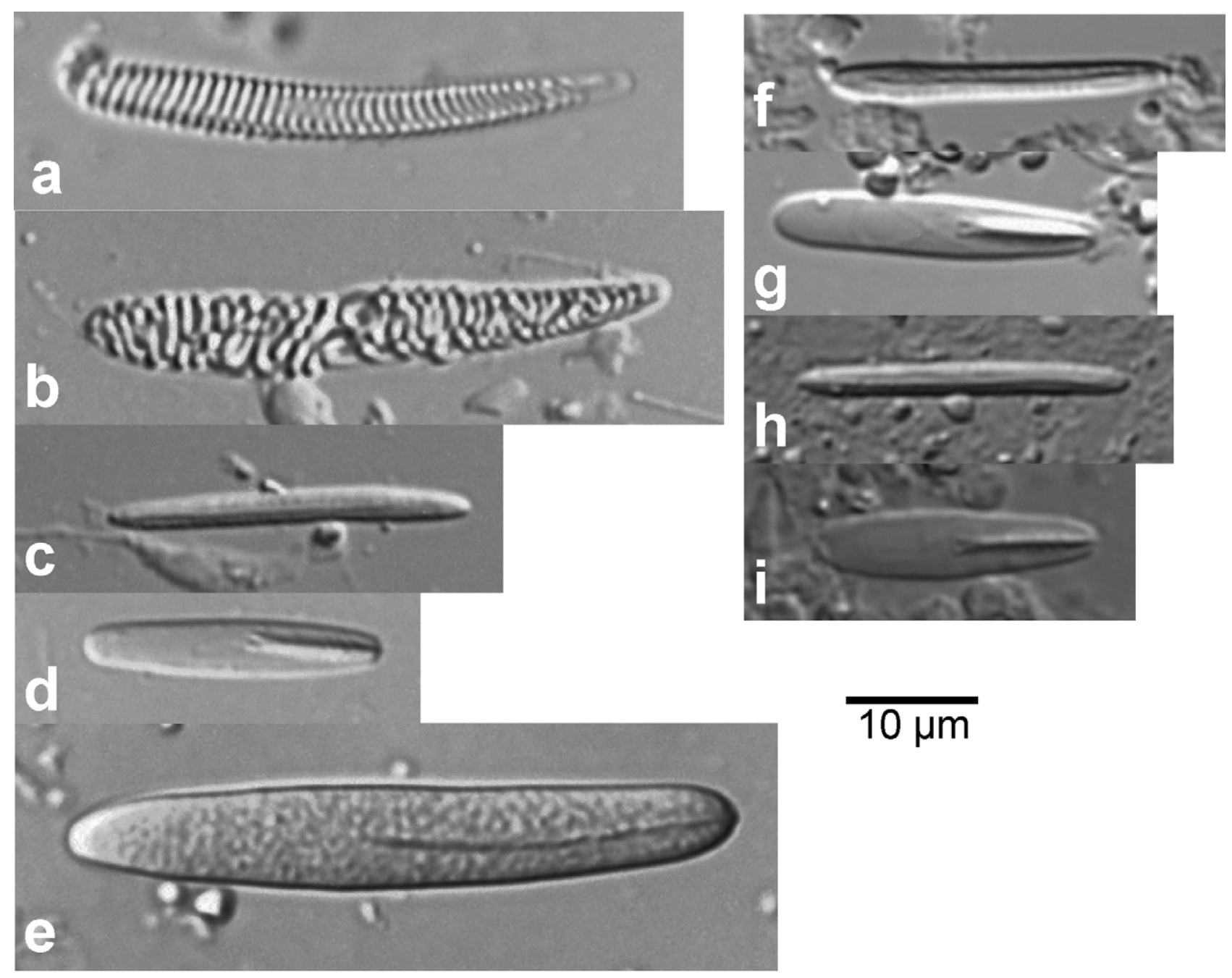

FIGURE 16. Cnidae of Actinostola faeculenta; distribution and dimensions in Table 3. a. Gracile spirocyst; b. robust spirocyst; c. basitrich; d. microbasic p-mastigophore; e. microbasic $b$-mastigophore; f. basitrich; g. microbasic $p$-mastigophore; h. basitrich; i. microbasic $p$-mastigophore.

Riemann-Zürneck (1971) questioned the basis of differentiating Actinostola from Paractinostola. She subsequently (Riemann-Zürneck 1978) placed P. bulbosa and P. capensis in Actinostola, finding the features Carlgren (1928a) used to define Paractinostola insufficient to distinguish it from Actinostola; however, she did not mention P. faeculenta.

The key distinction between Cymbactis, as described by McMurrich (1893), and Actinostola, as described by Carlgren (1949), is the lobed margin of members of Cymbactis. Riemann-Zürneck (1978) noted that the margin of some specimens belonging to species of Actinostola can be lobed. Additionally, C. faeculenta, the type species of Cymbactis, has more tentacles than mesenteries at the base, a character not true for Actinostola according to Carlgren (1949). Häussermann (2005 [correction to Häussermann 2004]), who analyzed the variability of characters in Actinostola chilensis McMurrich, 1904, found that some individuals of the species had more tentacles than mesenteries at the base and some had fewer. Thus these features do not distinguish Cymbactis from Actinostola. In examining fertile specimens of $C$. faeculenta, we found the first two cycles of mesenteries to be sterile; this state characterizes Actinostola. Therefore, Cymbactis conforms to the genus description of Actinostola, so Cymbactis is a junior synonym of Actinostola.

Material examined. See Appendix 7. 




FIGURE 17. Distribution of Actinostola faeculenta in North Pacific Ocean.

TABLE 3. Cnidae size and distribution of Actinostola faeculenta.

\begin{tabular}{llll}
\hline Tissue and Cnida Type & Length $\mathbf{x}$ Width $(\boldsymbol{\mu m})$ & $\mathbf{n}$ & $\mathbf{N}$ \\
\hline Tentacles & & & \\
Gracile Spirocysts (a) & $20.2-50.4 \times 2.6-5.3$ & 105 & $4 / 4$ \\
Robust Spirocysts (b) & $(24.9) 27.2-58.5(62.2) \times 3.2-7.5(7.9)$ & 103 & $4 / 4$ \\
Basitrichs (c) & $19.9-33.5(37.2) \times 1.9-3.1$ & 138 & $4 / 4$ \\
Microbasic $p$-mastigophores (d) & $17.3-26.0(27.4) \times 3.1-5.4$ & 91 & $4 / 4$ \\
Microbasic $b$-mastigophores (e) & $38.5-56.9 \times 6.5-10.8$ & 70 & $3 / 4$ \\
Actinopharynx & & & \\
Basitrichs (f) & $22.4-31.2 \times 2.3-3.1$ & 31 & $3 / 3$ \\
$\quad$ Microbasic $p$-mastigophores (g) & $19.9-26.9(30.9) \times 3.4-5.4$ & 27 & $3 / 3$ \\
Mesenterial Filaments & & & \\
Basitrichs (h) & $(23.0) 24.4-33.9 \times 2.3-3.4(3.6)$ & 31 & $3 / 3$ \\
Microbasic $p$-mastigophores (i) & $18.4-28.3 \times 4.1-6.1(6.9)$ & 30 & $3 / 3$ \\
\hline
\end{tabular}




\section{Genus Sicyonis Hertwig, 1882}

Sicyonis careyi $\mathbf{n}$. sp.

(Figures 18-21, Table 4, Appendix 8)

Body form and size. Column of specimens white to light grey (color of exposed mesoglea). Stiff due to thick mesoglea (to $6 \mathrm{~mm}$ mid-column in specimen $39 \mathrm{~mm}$ long); smooth except for few shallow irregular furrows; mesenterial insertions rarely visible. Cylindrical column of preserved specimens may be slightly compressed laterally (likely due to compression in collecting net), tentacles partially hidden in all specimens examined. Oral and pedal disc approximately same diameter, or column may taper slightly from oral to pedal disc (Figure 18). Column of most specimens examined 33-56 mm long, shortest $10 \mathrm{~mm}$ long.

Pedal disc. Pinkish brown; smooth but rare furrows may mark insertions of mesenteries toward periphery. Typically 24-42 mm diameter (7 mm diameter in smallest specimen); concave, concavity reaching $16 \mathrm{~mm}$ long; typically grasping bolus of mud.

Oral disc and tentacles. Tan or brown, radially furrowed where mesenteries insert; hidden by tentacles and contracted column in all specimens examined. Diameter $34-48 \mathrm{~mm}$ (13 $\mathrm{mm}$ in smallest), roughly same diameter as column length. Mouth about 1/3 diameter of oral disc, same color as oral disc; two large white siphonoglyphs apparent.

Tentacles tan, circumferentially furrowed, slightly thickened aborally at base (Figure 19a); arrayed in 3 cycles, about 80 in number (58 in smallest specimen). Inner tentacles endocoelic and larger than outer (exocoelic); short, pointed, 2-8 mm long, taper from 2-4 $\mathrm{mm}$ at base to $0.5-1 \mathrm{~mm}$ at tip. Small pore at tip (Figure 19b) more apparent in endocoelic than exocoelic tentacles.

Internal anatomy. Actinopharynx tan, brown, or grey, long, longitudinally sulcate. Each of two deep, white siphonoglyphs attached to pair of directive mesenteries.

Mesenteries thin and numerous (about 80 pairs), irregularly arrayed; incomplete ones loosely follow Actinostola rule. Mesenteries of youngest cycle very thin and weak, exist only at extreme proximal end; lack filaments and musculature, possess gametogenic tissue (Figure 19c). All other mesenteries muscular with filaments and large mesogleal thickenings distally (Figure 19d). Mesenteries of second youngest cycle (typically 20 pairs) extend from pedal to oral disc but very small compared to those of older cycles; rarely possess gametogenic tissue. Oldest mesenteries (typically 20 pairs) sterile and long; most complete, although only one member or rarely both members of pair incomplete; contain oral but no marginal stomata.

Muscular mesenteries possess long, diffuse retractor muscles. Parietobasilar muscles weak, pennons lacking. Mesogleal marginal sphincter muscle weak and moderately long; lies against endoderm (Figure 19e), may be longitudinally striated distally. Occupies less than half column width distally, where alveoli large and loosely arrayed; tapers proximally, where more reticular toward endoderm, alveolar toward ectoderm.

Longitudinal musculature of tentacles mesogleal and well developed (Figure 19a).

Cnidae. Spirocysts, basitrichs, holotrichs, microbasic $p$-mastigophores. Sizes and distribution of cnidae given in Table 4; cnidae illustrated in Figure 20.

Type specimens. Holotype: SBMNH 422541, collected 18-Feb-1971 from $45.31^{\circ} \mathrm{N} 126.53^{\circ} \mathrm{W}, 2,750 \mathrm{~m}$. Column length $39 \mathrm{~mm}$, diameter of contracted distal end $46 \mathrm{~mm}$, diameter of contracted proximal end $33 \mathrm{~mm} .72$ mesenteries span entire length of column and equal number gametogenic mesenteries exist only at proximal end; 72 tentacles.

Paratypes: KUIZ 003349, 3 specimens, collected 18-Feb-1971 from $45.31^{\circ} \mathrm{N} 126.53^{\circ} \mathrm{W}, 2,750 \mathrm{~m}$; CAS 184530, 1 specimen, collected 16-Mar- 1970 from $44.63^{\circ} \mathrm{N} 125.67^{\circ} \mathrm{W}, 2,816 \mathrm{~m}$; RBCM 010-00572-001, 1 specimen, collected 16-Mar-1970 from $44.63^{\circ} \mathrm{N} 125.67^{\circ} \mathrm{W}, 2,816 \mathrm{~m}$; USNM 1149363, 1 specimen, collected 16Mar-1970 from $44.63^{\circ} \mathrm{N} 125.67^{\circ} \mathrm{W}, 2,816 \mathrm{~m}$; SBMNH 149660, 2 specimens, collected 16-Mar-1970 from $44.63^{\circ}$ $\mathrm{N} 125.67^{\circ} \mathrm{W}, 2,816 \mathrm{~m}$.

Etymology. Named in honor of Andrew G. Carey, Jr. who collected specimens of this species, as well as many other deep-sea anemones, off the coast of Oregon.

Distribution. Sicyonis careyi n. sp. appears endemic to the northeastern Pacific, where it occurs from 550 to 3,700 $\mathrm{m}$ (Figure 21). No other member of the genus is known from the northeastern Pacific.

Taxonomic remarks. The genera Parasicyonis Carlgren, 1921, and Synsicyonis Carlgren, 1921, are so similar to Sicyonis that species in them merit comparison with Sicyonis careyi n. sp. 




FIGURE 18. Specimens of Sicyonis careyi n. sp. Large holotype specimen on left (SBMNH 422541); two small paratypes specimens on right (KUIZ 003349).

TABLE 4. Cnida size and distribution of Sicyonis careyi n. sp. Shorter specimens have smaller cnidae. * Sparse.

\begin{tabular}{|c|c|c|c|}
\hline Tissue and Cnida Type & Length $x$ Width $(\mu \mathrm{m})$ & $\mathbf{n}$ & $\mathbf{N}$ \\
\hline \multicolumn{4}{|l|}{ Tentacles } \\
\hline Gracile spirocysts (a) & $25.3-49.9(54.3) \times 2.9-4.8(5.2)$ & 33 & $3 / 3$ \\
\hline Robust spirocysts* (b) & (33.0) 35.4-50.9 (55.9) x (4.4) 4.8-6.0 & 17 & $3 / 3$ \\
\hline Basitrichs (c) & $27.6-45.5 \times 3.3-4.2$ & 37 & $3 / 3$ \\
\hline Holotrichs (d) & $25.9-47.0 \times(3.2) 3.4-4.3(4.6)$ & 42 & $3 / 3$ \\
\hline \multicolumn{4}{|l|}{ Actinopharynx } \\
\hline Basitrichs (e) & $32.3-43.3(46.2) \times 3.2-4.5(4.8)$ & 34 & $3 / 3$ \\
\hline Microbasic $p$-mastigophores (f) & $22.9-29.9 \times 4.9-6.0$ & 30 & $3 / 3$ \\
\hline \multicolumn{4}{|l|}{ Mesenterial Filaments } \\
\hline Basitrichs (g) & $26.2-35.9 \times 5.0-6.8$ & 31 & $3 / 3$ \\
\hline Microbasic $p$-mastigophores (h) & (15.2) $18.5-32.1 \times 4.1-6.3(6.8)$ & 31 & $3 / 3$ \\
\hline
\end{tabular}



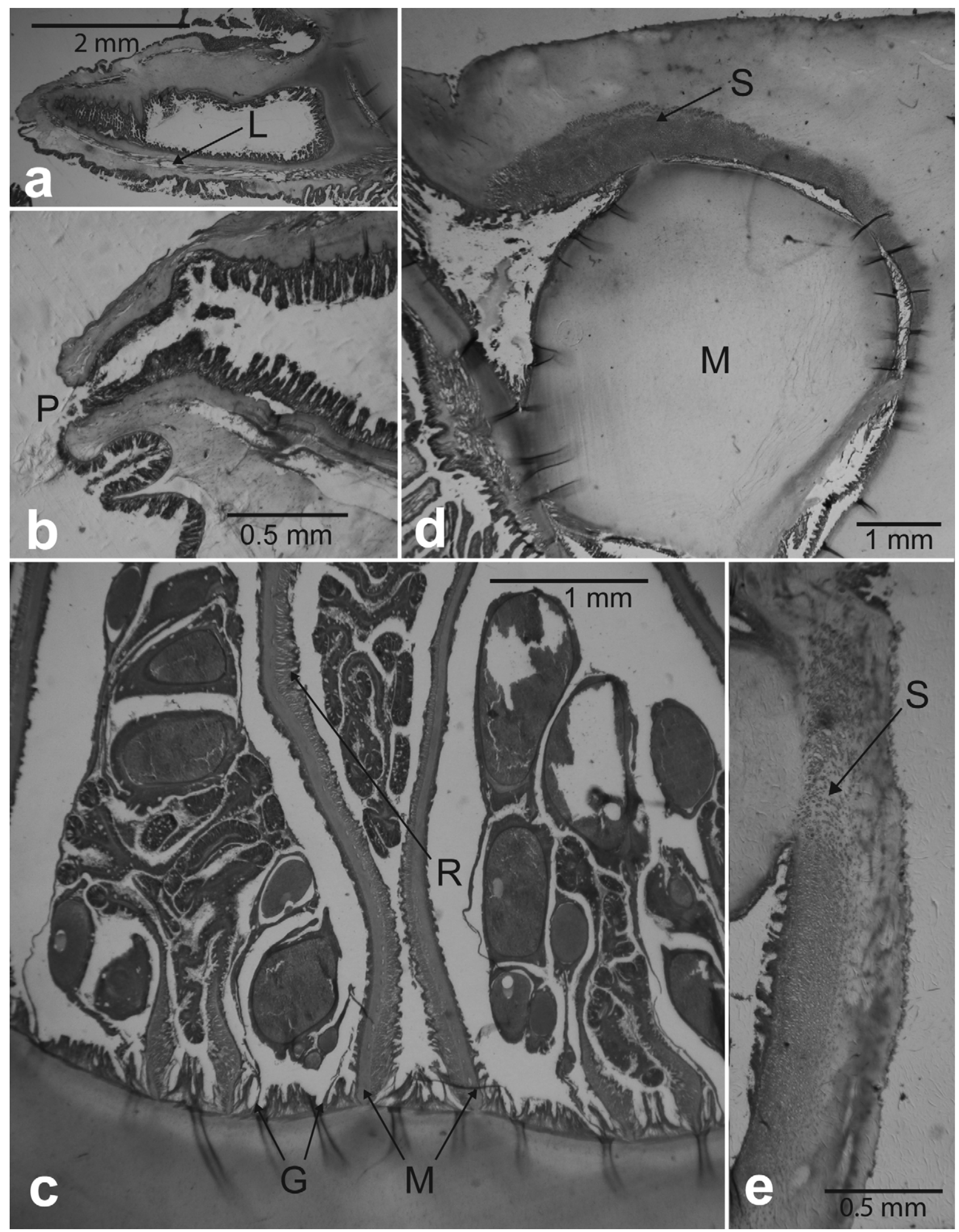

FIGURE 19. Sicyonis careyi $\mathrm{n}$. $\mathrm{sp}$. a. Tentacle with mesogleal longitudinal musculature (L); b. tentacle pore (P); c. muscular mesenteries (M) with diffuse retractor muscles (R) and non-muscular fertile mesenteries (G); d. mesogleal sphincter muscle (S) and thickened mesoglea at distal end of mesenteries (M); e. mesogleal sphincter muscle (S). 


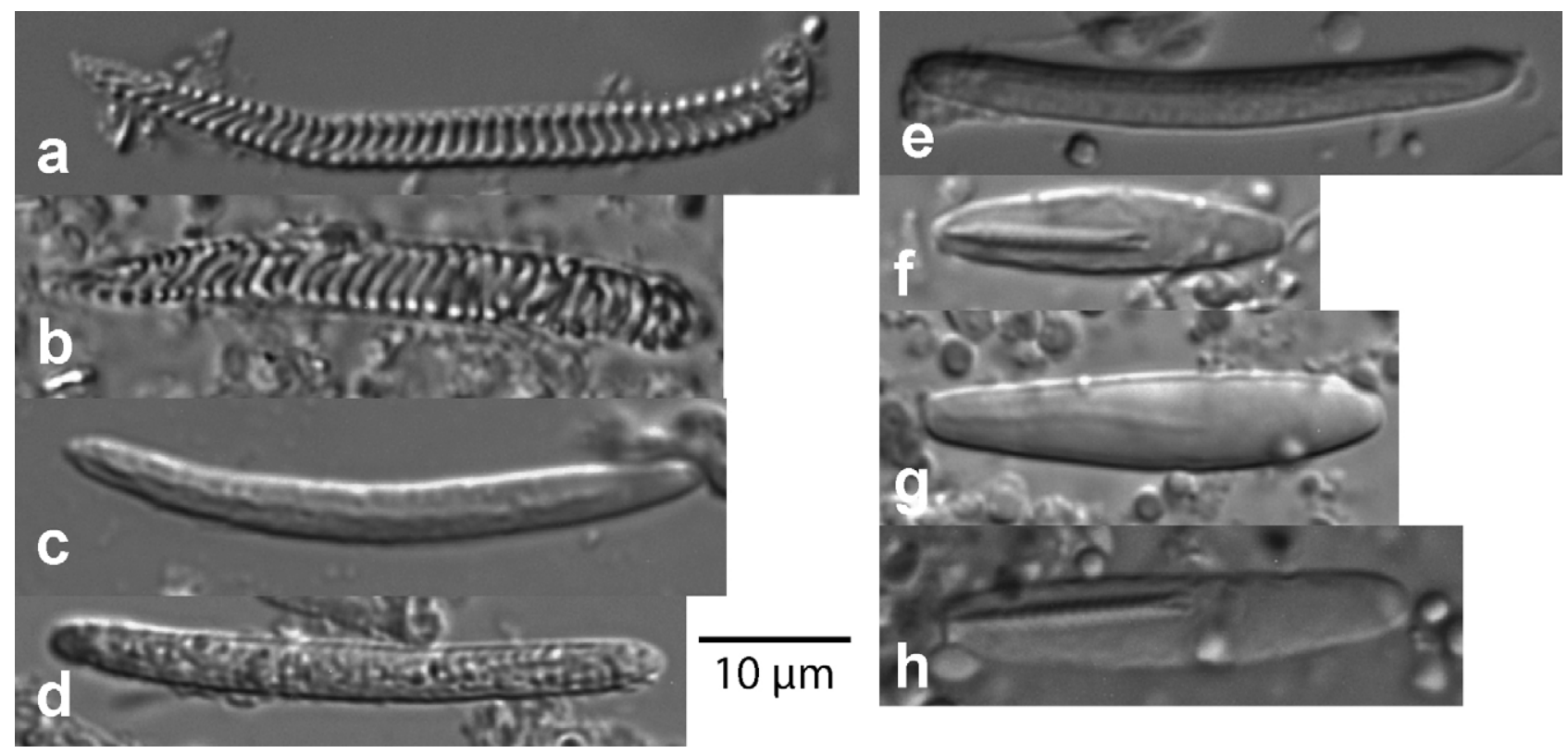

FIGURE 20. Cnidae of Sicyonis careyi n. sp.; distribution and dimensions in Table 4. a. Gracile spirocyst; b. robust spirocyst; c. basitrich; d. holotrich; e. basitrich; f. microbasic p-mastigophore; g. basitrich; h. microbasic p-mastigophore.

In both Synsicyonis and Sicyonis, mesenteries of the last cycle are fertile and lack filaments; the last cycle occurs only at the extreme distal end of the column in members of Synsicyonis and at the extreme proximal end of the column in members of Sicyonis. The only species of Synsicyonis, S. elongata (Hertwig, 1888), is known from the middle of the North Pacific at 5,304 m; mesenteries of its youngest cycle are muscular.

Mesenteries of the youngest cycle are fertile in members of Parasicyonis and Sicyonis; however, those of Parasicyonis possess mesenterial filaments, and those of Sicyonis lack mesenterial filaments. No species of Parasicyonis have been recorded from the Pacific Ocean.

In describing the North Atlantic Sicyonis biotrans Riemann-Zürneck, 1991, which possesses small filaments on mesenteries of the youngest cycle, Riemann-Zürneck (1991) argued that this character is not stable in Sicyonis. However, she did not provide evidence for that assertion, and the character appears consistent, to judge by specimens of Sicyonis we examined and descriptions of other species in the genus we read. Because the presence or absence of filaments on mesenteries of the youngest cycle is the only feature distinguishing the genera, and we are aware of no evidence that this character is unstable, the species is properly Parasicyonis biotrans (RiemannZürneck, 1991).

Material examined. See Appendix 8.

Differential diagnosis. Sicyonis careyi $\mathrm{n}$. sp. can be distinguished from its congeners by its combination of: smooth mesoglea; smooth and thin pedal disc; weak alveolar marginal sphincter muscle; oral stomata; about 80 aborally thickened tentacles; about 80 pairs of mesenteries, of which those of the youngest and rarely the penultimate cycle are fertile. 


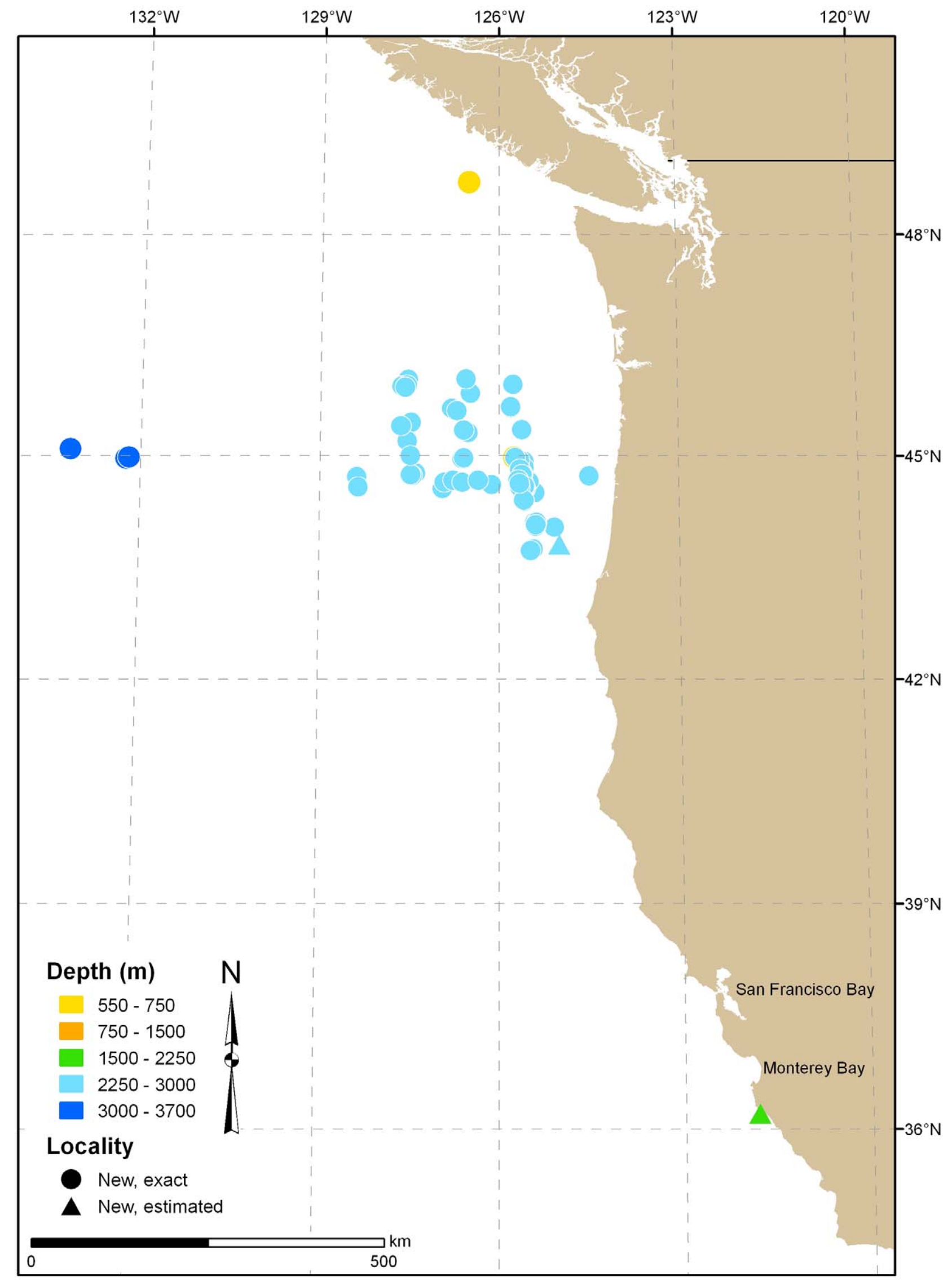

FIGURE 21. Distribution of Sicyonis careyi n. sp. from California to British Columbia. 


\section{Dichotomous key to species of Sicyonis.}

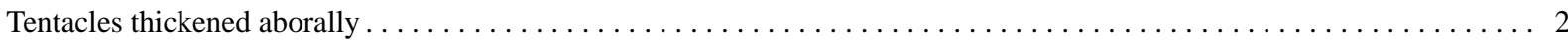
About 70 tentacles; not thickened aborally. About 100 pairs of mesenteries, to 21 pairs complete, some additional pairs with only one member complete; oral and marginal stomata present. North Atlantic Ocean . . . . . . . S. variabilis Carlgren, 1921 Basal aboral thickening of each tentacle does not project as large swollen bulb $\ldots \ldots \ldots \ldots \ldots \ldots \ldots \ldots \ldots \ldots \ldots . \ldots$ Basal aboral thickening of each tentacle projects as large swollen bulb. Marginal sphincter muscle mesh-like, interrupted by strips of mesoglea. Oral stomata on all mesenteries; marginal stomata only on stronger mesenteries. Some rare mesenteries of penultimate cycle fertile. North Atlantic Ocean . . . . . . . . . . . . . . . . . . . . . . . . . S. tuberculata Carlgren, 1921

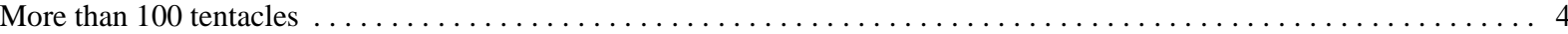

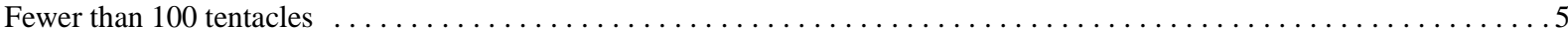
About 144 tapered tentacles, of differing lengths. 144 pairs of mesenteries. North Atlantic Ocean . . . . . . . . . . . . . . . About 200 large tentacles, all same length. To five cycles of mesenteries. Off Japan . . . . . . . . tubulifera (Hertwig, 1882) Marginal sphincter muscle well developed, half or more of width of mesoglea $\ldots \ldots \ldots \ldots \ldots \ldots \ldots \ldots \ldots \ldots$ Marginal sphincter muscle poorly developed, less than half width of mesoglea $\ldots \ldots \ldots \ldots \ldots \ldots \ldots \ldots \ldots \ldots$

6 Youngest mesenteries fertile, exist only near base. Column smooth, with shallow furrows distally; marginal sphincter muscle long, reticular near endoderm, alveolar near ectoderm. North Atlantic Ocean. . . . . . . . . . S. hemisphaerica Carlgren, 1934a Youngest mesenteries fertile, extend far distally. Column smooth; marginal sphincter muscle long, striated and reticular. Off

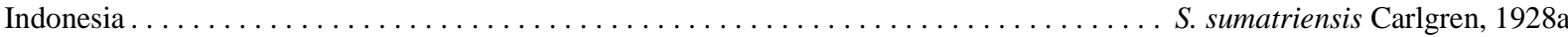

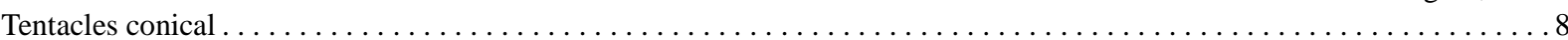
Tentacles wart-like. Column short with deep constriction in center. No microbasic $p$-mastigophores in actinopharynx. Southern

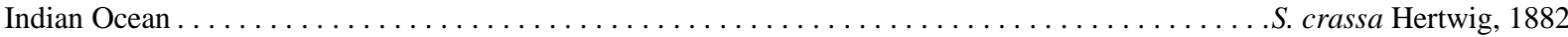
Only mesenteries of youngest cycle fertile; column longitudinally furrowed distally $\ldots \ldots \ldots \ldots \ldots \ldots \ldots \ldots \ldots \ldots$ Mesenteries of youngest cycle and other young ones fertile; column not longitudinally furrowed distally. One size class of

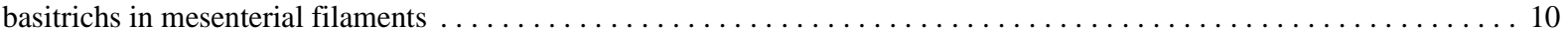

9 Marginal sphincter muscle more alveolar than reticular, not stratified. Column approximately twice as wide as long. Fifteen pairs of mesenteries plus one additional member of a single pair complete. North Atlantic Ocean . . . . . . . . . . . . .


Marginal sphincter muscle alveolar and stratified. Column only slightly wider than long. At least 16 pairs of mesenteries complete; single members of additional mesentery pairs may be complete. Oral and marginal stomata present; marginal stomata typically on only stronger mesenteries. North Atlantic Ocean . . . . . . . . . . . . . . . . S. ingolfi Carlgren, 1921

10 Column smooth, typically circumferentially furrowed proximally, pink to red ectoderm typically in furrows; mesoglea fibrous distally. Oral stomata present. Pedal disc brown, thick, furrowed. Marginal sphincter muscle reticular. Microbasic $p$ mastigophores in actinopharynx; basitrichs of mesenterial filaments $13-20 \mu \mathrm{m}$ long. Southern Ocean . . . . . . . . . . .

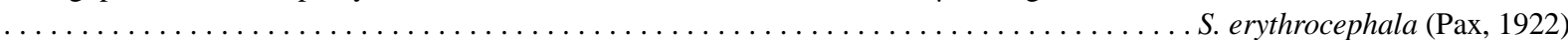
Column white, smooth, with very shallow irregular furrows (likely artifact of collection), devoid of ectoderm; mesoglea smooth, not fibrous. Oral stomata present. Pedal disc pinkish-brown, furrowed only near limbus, thin. Marginal sphincter muscle with large alveoli distally; proximally reticular toward endoderm, alveolar toward ectoderm. Microbasic $p$ mastigophores in actinopharynx; basitrichs of mesenterial filaments $26-36 \mu \mathrm{m}$ long. Northeastern Pacific Ocean.

S. careyi n. sp.

\section{Family Bathyphelliidae Carlgren, 1932}

\section{Genus Bathyphellia Carlgren, 1932}

\section{Bathyphellia australis Dunn, 1982}

(Figures 22-23, Appendix 9)

Synonym

\section{Daontesia australis: Riemann-Zürneck (1994)}

Diagnosis. Elongate column (to about $30 \mathrm{~mm}$ ) tapered distally. Scapus rough, dark, covered in tenaculi holding multistratified cuticle and typically debris; where tenaculi sloughed, scapus tan, smooth. Scapus short, smooth, orangish. Margin of most specimens contracted, oral disc hidden. Pedal disc typically attached to manganese nodule (Figure 22). Mesenteries in three cycles, all with somewhat restricted diffuse retractor muscles; six pairs of macrocnemes. Acontia small, difficult to locate (as is common in members of family Bathyphelliidae [Carlgren 1956; Dunn 1983; Riemann-Zürneck 1997]). For a detailed description of B. australis, see Dunn (1983).

Cnidae. Spirocysts, basitrichs, microbasic $p$-mastigophores. 
Distribution. Bathyphellia australis was described from five specimens collected in the South Pacific Ocean at 3,200-4,575 $\mathrm{m}$ (Dunn 1983). The hundreds of specimens we have examined from California to Oregon extend the species' range geographically and to as shallow as 2,709 $\mathrm{m}$ (Figure 23). We infer that members of B. australis occur all along the eastern rim of the Pacific Ocean at appropriate depths.

Taxonomic remarks. Being congeners, Bathyphellia australis and B. margaritacea (Danielssen, 1890) resemble one another in some respects. They differ in geographic distribution and microhabitat, the latter recorded only from the North Atlantic and Arctic Oceans (Danielssen 1890; Carlgren 1942; Doumenc 1975; RiemannZürneck 1997; Sanamyan et al. 2009), embedded in soft sediment. Although similar, their cnidae differ. The tall cylindrical form of $B$. australis is virtually invariant because its dense tenaculi prevent it from shortening, whereas that of B. margaritacea is "trumpet-shaped" and variable in length:width ratio (Sanamyan et al. 2009: 1246). We found small acontia in all specimens of $B$. australis but, according to Sanamyan et al. (2009) they may be absent in some specimens of B. margaritacea.

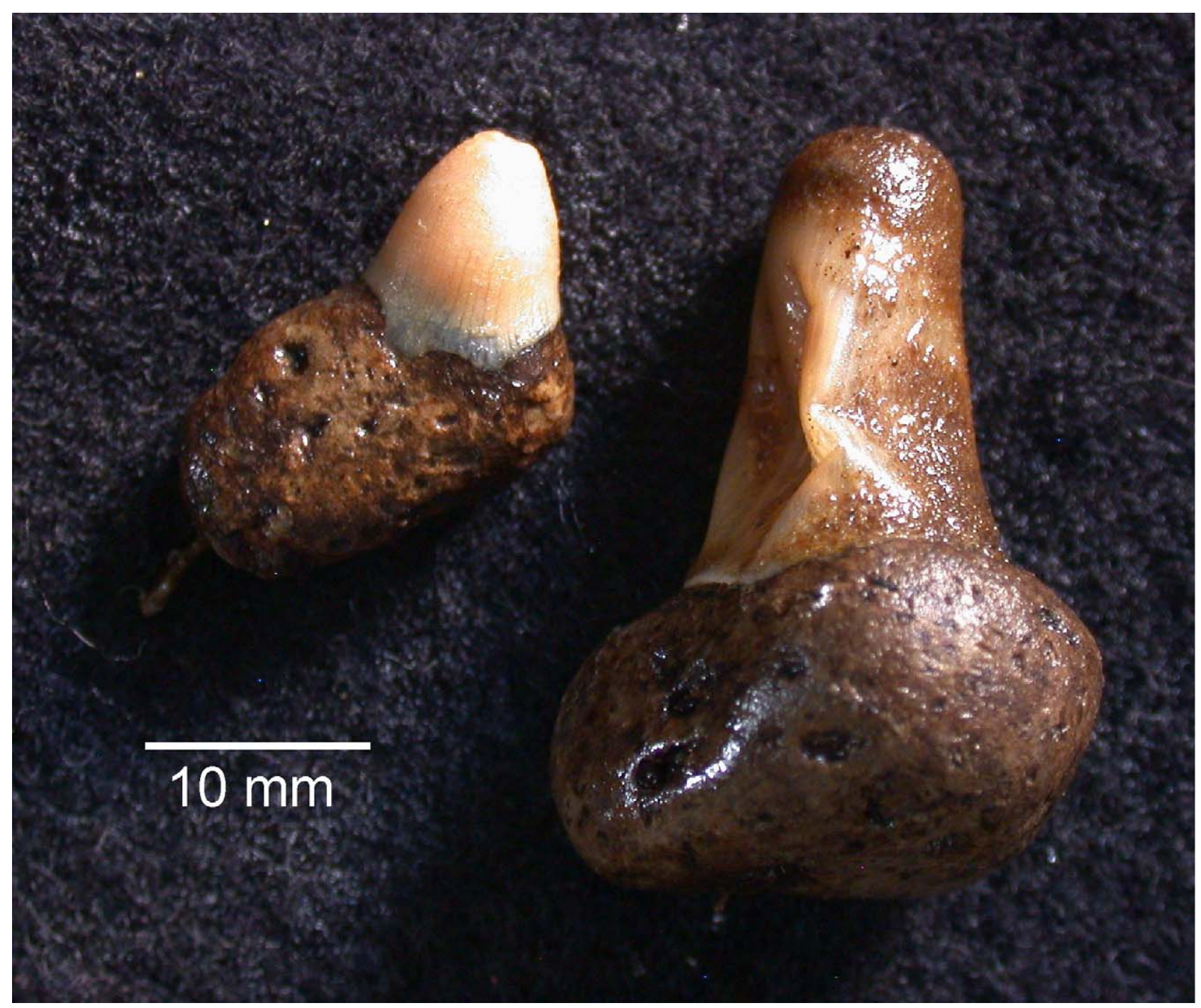

FIGURE 22. Specimens of Bathyphellia australis, each attached to a manganese nodule (KUIZ 002167). 




FIGURE 23. Distribution of Bathyphellia australis in Southern and northeastern Pacific Ocean.

Riemann-Zürneck (1997) moved Bathyphellia australis to Daontesia Carlgren, 1942 in light of her revised definition of the genus, giving primacy to the character of a multistratified cuticle, a feature shared with the type species of the genus, Daontesia praelonga (Carlgren, 1928b), as noted by Dunn (1982). Two characters separate 
Daontesia and Bathyphellia in the key of Carlgren (1949), the number of macrocnemes (12 in the former, six in the latter) and the number of tentacles (same as the number of mesenteries in the former, fewer in the latter). RiemannZürneck (1997: 367) did not mention the number of tentacles in her revised definition of Daontesia but stated the number of macrocnemes as "six or 12 pairs," despite both D. praelonga and D. porcupina Riemann-Zürneck, 1997, having only six pairs, and added to the definition "Tentacle ectoderm with a peculiar $b$-mastigophore." Cinclides may occur in Daontesia. Bathyphellia australis has 12 macrocnemes and lacks cinclides; we have not found in the tentacles the distinctive type of nematocyst characterizing Daontesia. We therefore retain B. australis in the genus Bathyphellia.

Material examined. See Appendix 9.

\section{Family Hormathiidae Carlgren, 1932}

\section{Genus Actinauge McMurrich, 1893}

\section{Actinauge verrillii McMurrich, 1893}

(Figures 24-25, Appendix 10)

Synonyms: see below

Diagnosis. Shape depends on substratum: most specimens attached to gastropod shell, cylindrical object such as worm tube or sponge spicules, or bolus of mud. Column to $46 \mathrm{~mm}$ long. Scapus covered in tubercles; tubercles small toward base, more pronounced toward margin; brown cuticle typically remains only in furrows between tubercles (Figure 24). In specimens examined, column contracted, hiding oral disc; tentacles rarely visible. Same number of tentacles as mesenteries (about 96: four cycles); tentacles tapered, thickened aborally. For detailed information on A. verrillii, see McMurrich (1893) and Dunn (1983).

Cnidae. Spirocysts, basitrichs, microbasic $p$-mastigophores.

Distribution and taxonomic remarks. Actinauge verrillii was originally described from 15 specimens collected from off the Galapagos Islands, Chile, and the Channel Islands of California from 717, 1,238, and 757 m, respectively (McMurrich 1893). Specimens have also been trawled in the Southern Ocean (Dunn 1983).

Additionally, the species has been reported from the Atlantic Ocean in trawls as shallow as 0-450 m but those records are incorrect (see Carlgren 1949; Riemann-Zürneck 1986). Riemann-Zürneck (1986) described the species Actinauge cristata Riemann-Zürneck, 1986, from the northwestern Atlantic Ocean for specimens that had been identified as $A$. verrillii.

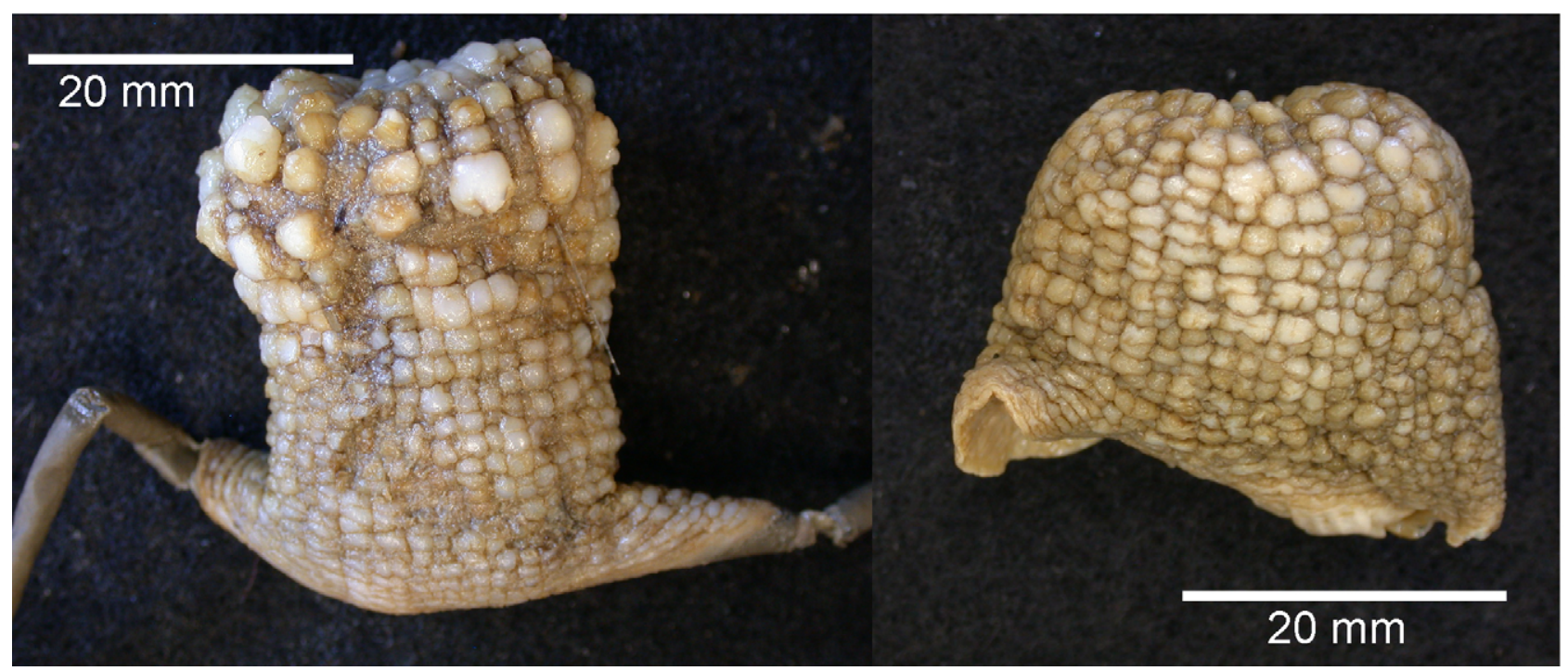

FIGURE 24. Specimens of Actinauge verrillii. Voucher specimen on left (SBMNH 422707) attached to worm tube; syntype specimen on right (USNM 17807). 
Thus, A. verrillii appears to be restricted to the Southern and Pacific Oceans. Specimens we examined extended the species' previously known range to the Aleutian Islands and to depths of at least $119 \mathrm{~m}$ to $4,250 \mathrm{~m}$ (see Appendix 10) (Figure 25).

Material examined. See Appendix 10.

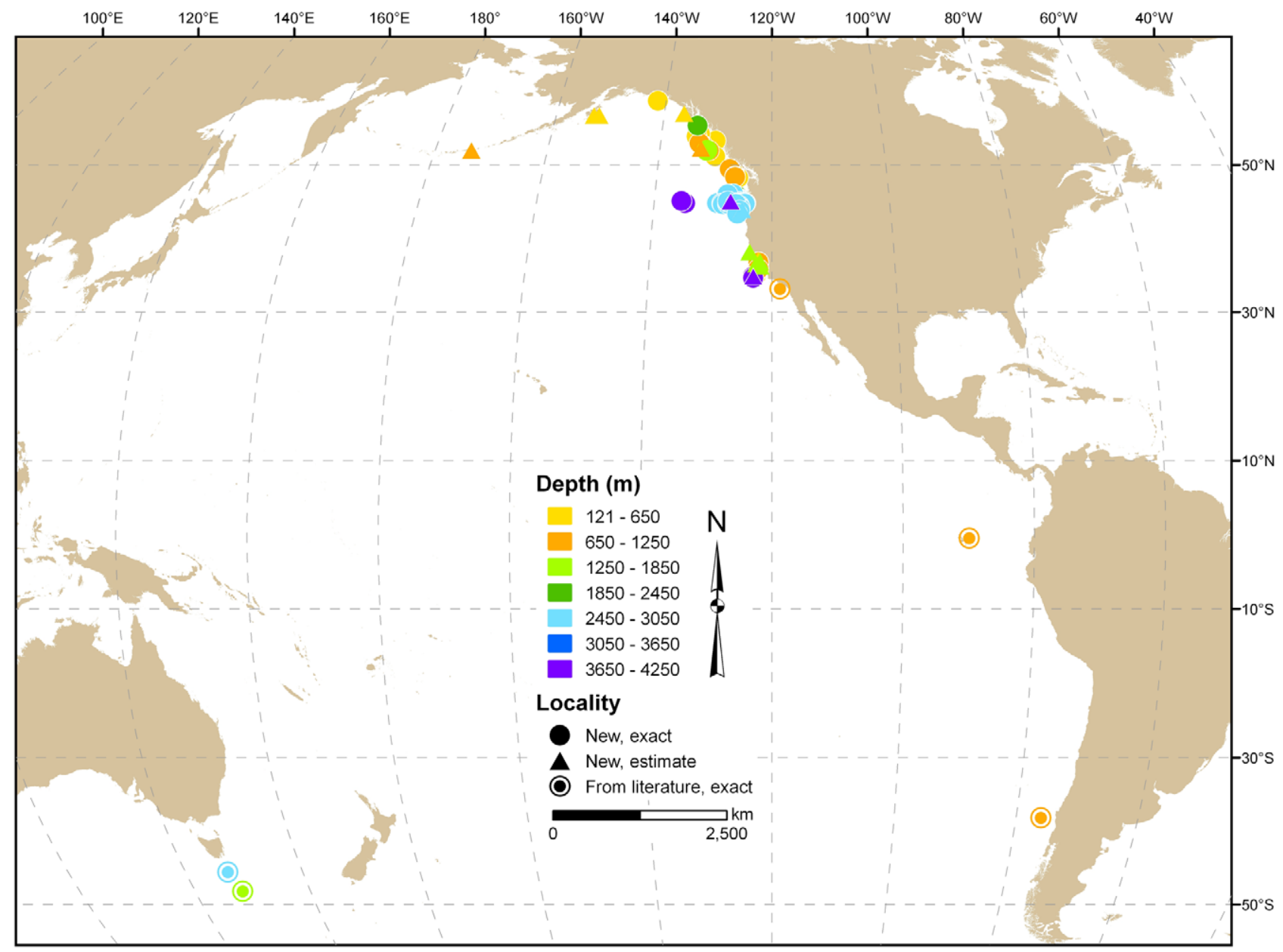

FIGURE 25. Distribution of Actinauge verrillii in Southern and Pacific Oceans.

\section{Genus Monactis Riemann-Zürneck, 1986}

\section{Monactis vestita (Gravier, 1918)}

(Figures 26-27, Appendix 11)

Synonym

\section{Paractis vestita: Gravier, 1918}

Diagnosis. Body form (Figure 26) presumably depends on object attached to (gastropod, rock, cylindrical object); body tall, flat, or elongate. Diameter of pedal disc to approximately $40 \mathrm{~mm}$; length of column to $18 \mathrm{~mm}$. Column tan, smooth; margin typically contracted so oral disc hidden. About 32 tentacles; may be hidden by contracted margin. Mesenteries arrayed in four cycles; those of only first cycle complete and with acontia. Acontia difficult to distinguish from filaments. For detailed information on M. vestita, see Gravier (1918), Riemann-Zürneck (1986), Zamponi and Acũna (1992), and White et al. (1999).

Cnidae. Spirocysts, basitrichs, microbasic $p$-mastigophores. 
Distribution. Monactis vestita, the only species in its genus, was originally described from specimens collected from the northeastern Atlantic Ocean at 2,286 to 5,005 m (Gravier 1918). Animals of this species have been found off the coasts of Venezuela (Riemann-Zürneck 1986) and Oregon (White et al. 1999); we did not find additional specimens. The species is known in the Atlantic and Pacific Oceans from 59 to 5,320 m (Figure 27).

Material examined. See Appendix 11.

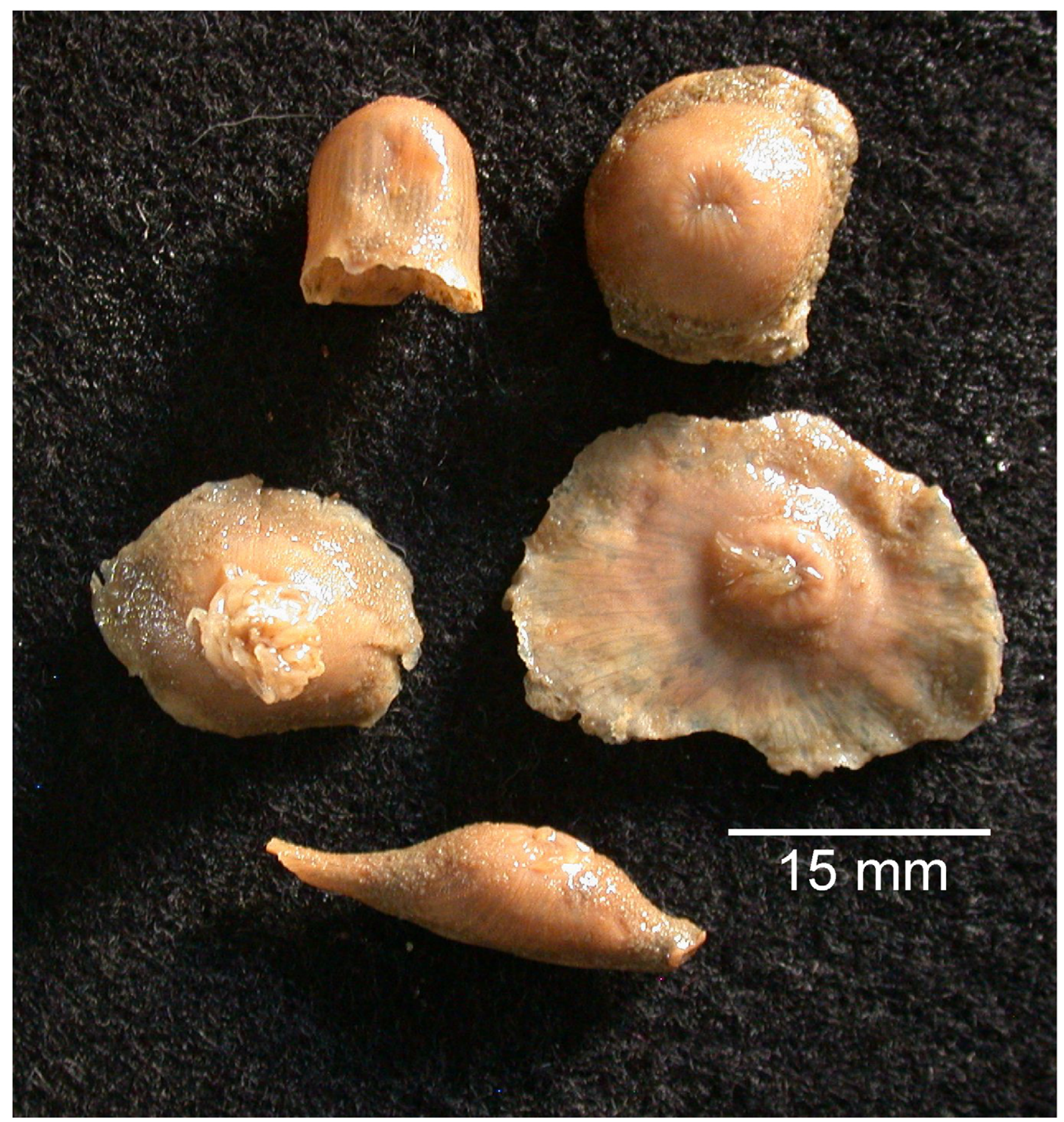

FIGURE 26. Specimens of Monactis vestita with a variety of body forms (KUIZ 001210). 


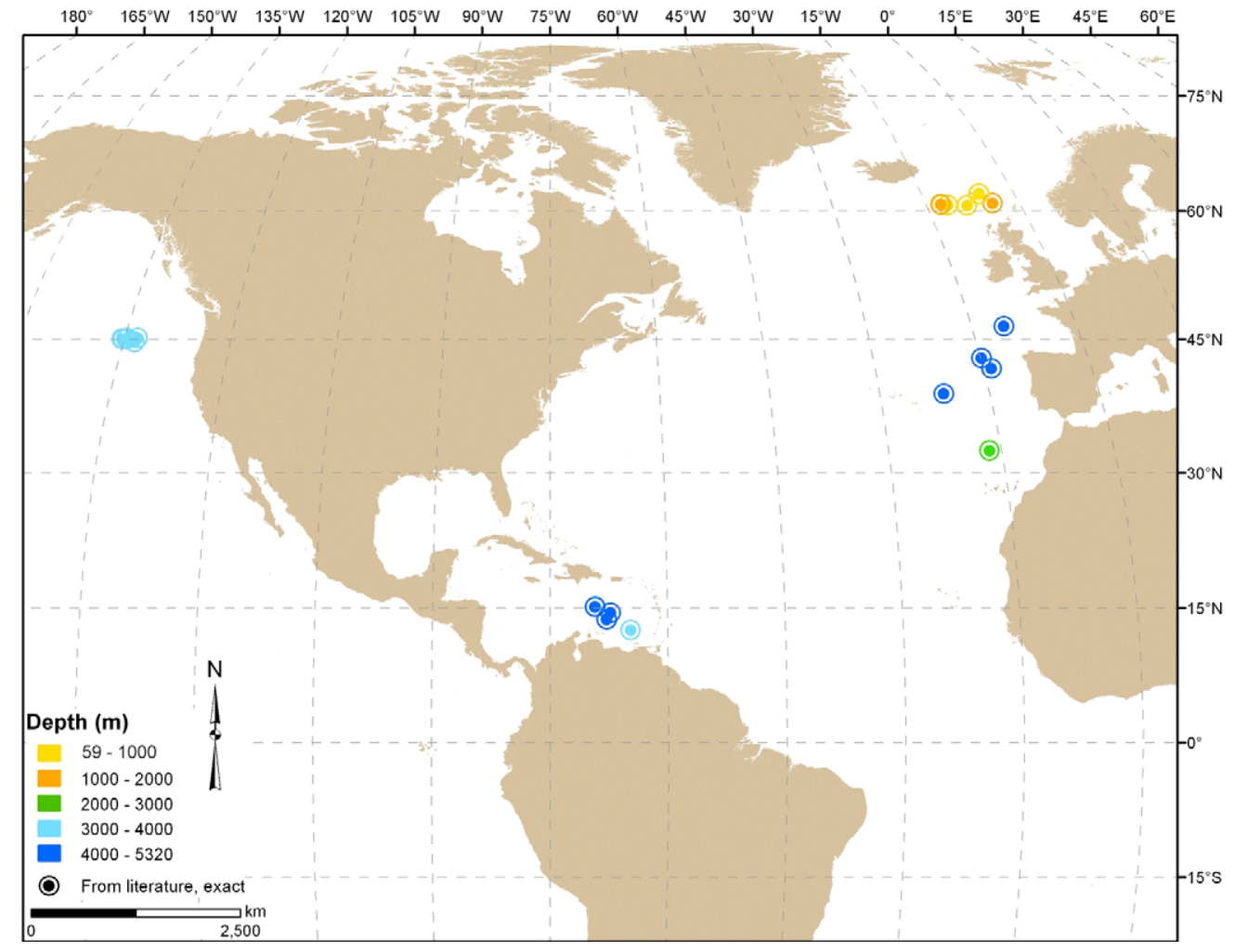

FIGURE 27. Distribution of Monactis vestita in North Atlantic and Pacific Oceans.

\section{Genus Paraphelliactis Carlgren, 1928b}

\section{Paraphelliactis pabista Dunn, 1982}

(Figures 28-29, Appendix 12)

No synonyms

Diagnosis. Column light tan to brown, 10 to $80 \mathrm{~mm}$ long; pointed tubercles arrayed in longitudinal rows along endocoels. Pedal disc often attached to cylindrical object such as worm tube (Figure 28) or holds small stone or bolus of mud. Aborally thickened tentacles more numerous than mesenteries at mid-column (to more than 150 tentacles vs. 96 mesenteries). For a detailed description of P. pabista, see Dunn (1982); Sanamyan and Sanamyan (2007) added information.

Cnidae. Spirocysts, basitrichs, microbasic $p$-mastigophores.

Distribution. Paraphelliactis pabista was described from off the coast of British Columbia (Dunn 1982). Sanamyan and Sanamyan (2007) reported the species in the Gulf of California, Mexico. We examined additional specimens from California to British Columbia and extend the depth range of the species to 1,426 to $4,100 \mathrm{~m}$ (Figure 29).

Taxonomic remarks. The other species of Paraphelliactis, P. spinosa Carlgren, 1928b (the type species) and P. michaelsarsi Carlgren, 1934a, were moved to Phelliactis Simon, 1892, by Riemann-Zürneck (1973). However, Riemann-Zürneck (1973) did not report the ratio of mesenteries to tentacles in specimens of the two species, key to distinguishing the genera. Thus, as Sanamyan and Sanamyan (2007) contended, the type species of Paraphelliactis ( $P$. spinosa) should be regarded as valid and Paraphelliactis pabista should remain the valid name of the species we examined from the northeastern Pacific.

Material examined. See Appendix 12. 




FIGURE 28. Specimen of Paraphelliactis pabista attached to worm tube (SBMNH 83609). 


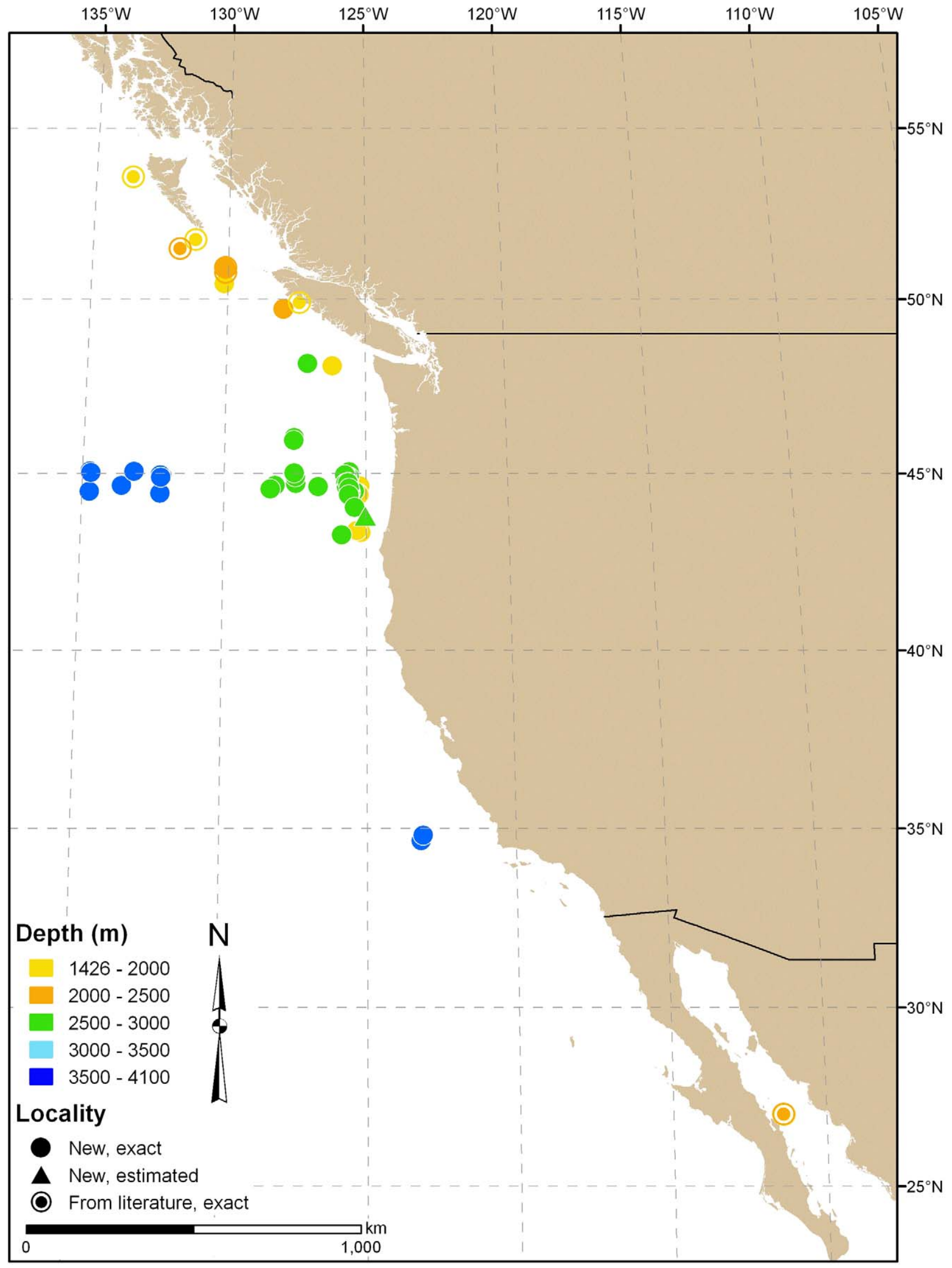

FIGURE 29. Distribution of Paraphelliactis pabista from Mexico to British Columbia. 


\section{Family Liponematidae Hertwig, 1882}

\section{Genus Liponema Hertwig, 1888}

\section{Liponema brevicorne (McMurrich, 1893)}

(Figures 30-31, Appendix 13)

Synonym

Bolocera brevicornis: McMurrich, 1893

Diagnosis. Oral disc of preserved specimens tan to pink; diameter to approximately $100 \mathrm{~mm}$, expanded so completely hides short column; covered in short tentacles (Figure 30), one tentacle per endocoel, more than one per exocoel. Tentacles deciduous (as typical for members of Liponema); sphincter muscle at base of each. Bottoms of jars with preserved specimens often filled with detached tentacles. For a detailed description of L. brevicorne, see McMurrich (1893); Dunn and Bakus (1977) redescribed the species.

Cnidae. Spirocysts, basitrichs, microbasic $p$-mastigophores.

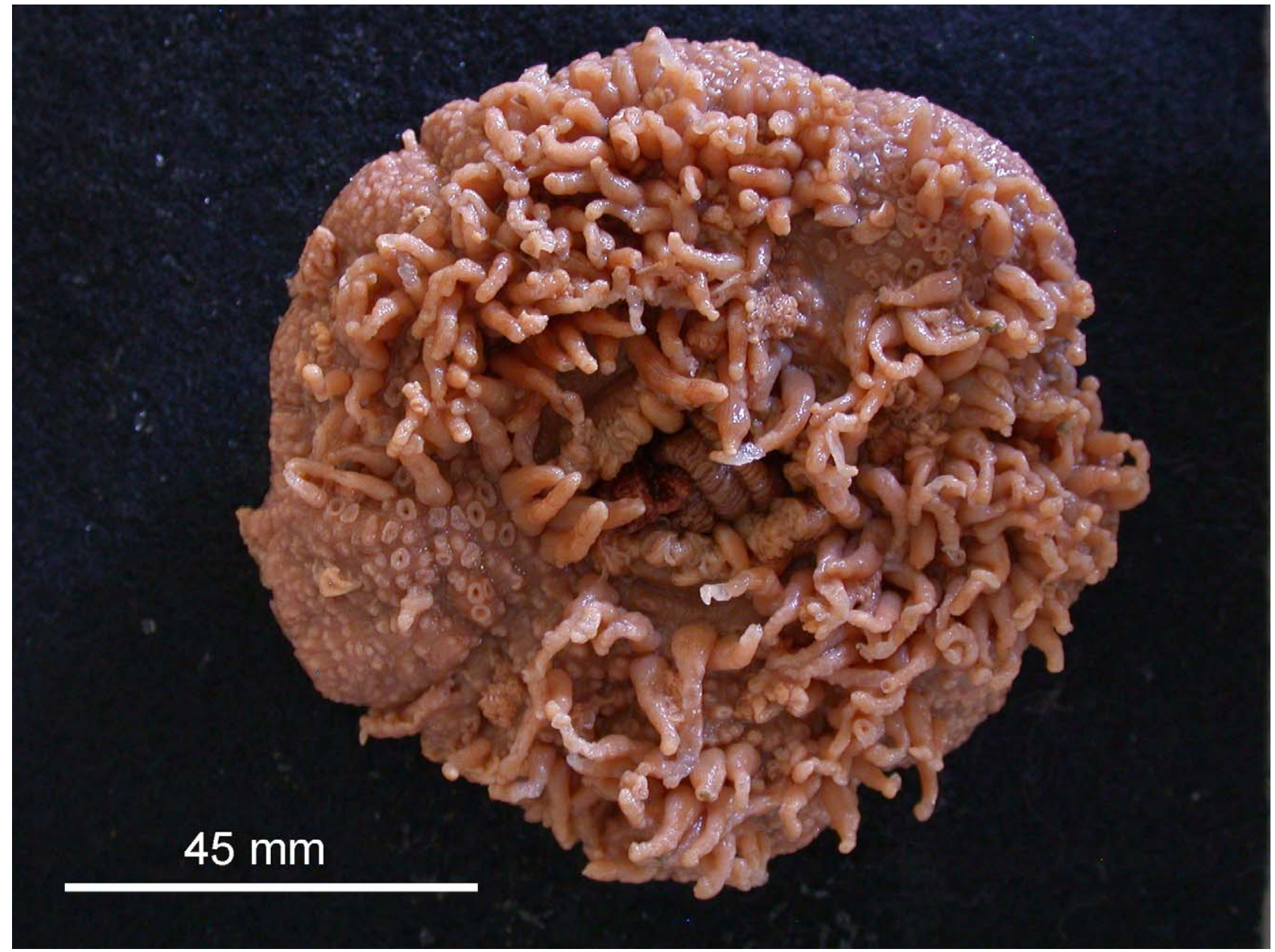

FIGURE 30. Oral disc of Liponema brevicorne missing about half its tentacles (KUIZ 003280).

Distribution. Liponema brevicorne was originally described from north of the Channel Islands, at $757 \mathrm{~m}$ (McMurrich 1893). Additional specimens, including some examined by us, have been collected throughout the North Pacific to the Aleutian Islands and Japan, extending the depth range of the species to 102 to 4,134 m (Figure $31)$.

In life, specimens are typically unattached on the sea floor (Dunn \& Bakus 1977). 
Taxonomic remarks. Bolocera, the genus in which this species was described, is feminine, so the species name was rendered brevicornis; the proper first Latin declension adjective form for the neuter genus, Liponema, is brevicorne.

Material examined. See Appendix 13.

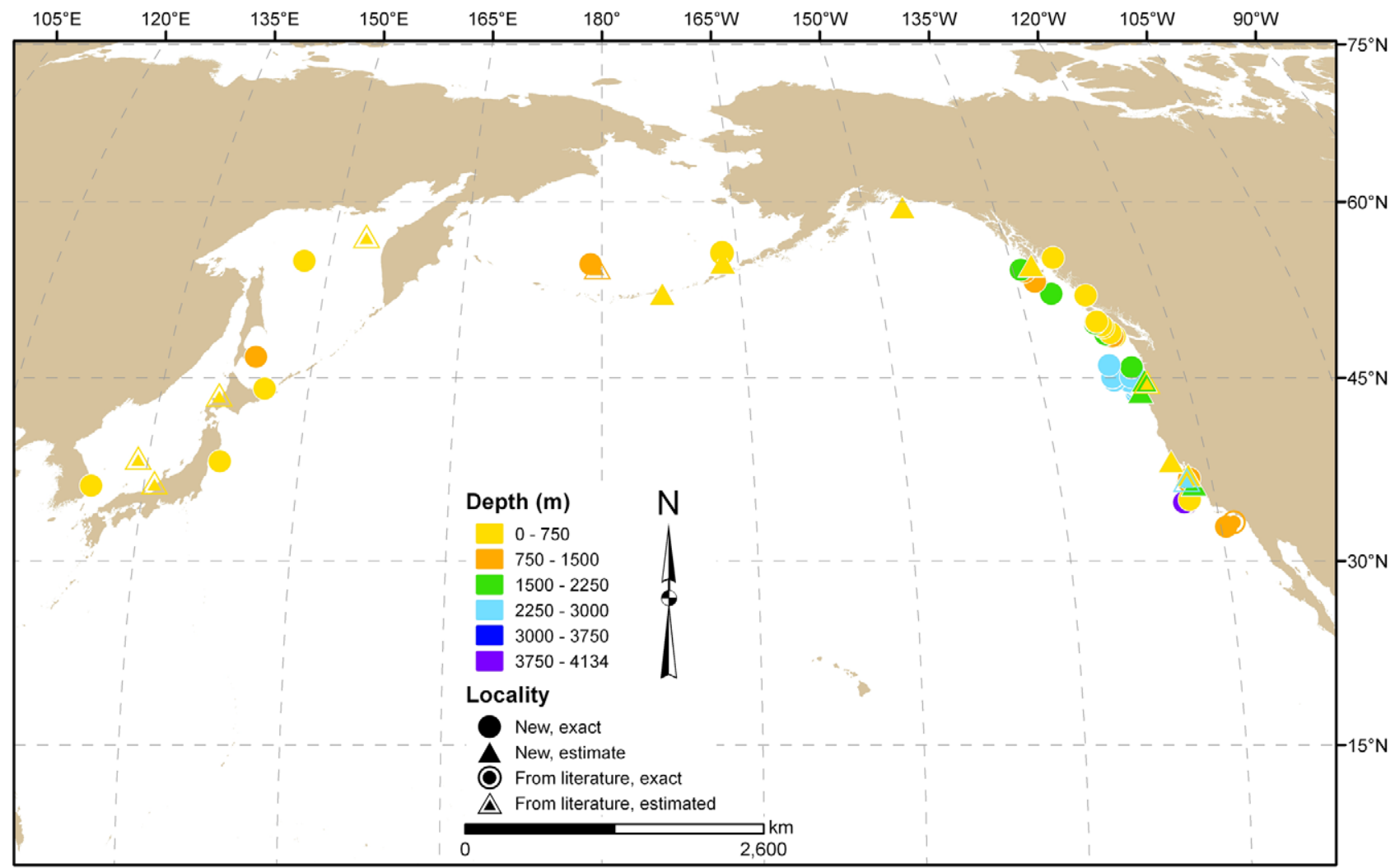

FIGURE 31. Distribution of Liponema brevicorne from southern California to Japan.

\section{Family Metridiidae Carlgren, 1893}

\section{Genus Metridium de Blainville, 1824}

\section{Metridium farcimen (Brandt, 1835)}

(Figures 32-33, Appendix 14)

Synonyms: see Fautin and Hand (2000)

Diagnosis. Specimens to $1 \mathrm{~m}$ long in life (Fautin et al. 1989); preserved specimens greatly contracted (100 mm or less in length). Column smooth, white to pale salmon or brown. Margin typically contracted, partially or completely hiding oral disc (Figure 32). Oral disc with lobes thickened with mesoglea. Oral disc covered in hundreds of tentacles; marginal tentacles shorter than discal tentacles. Pedal disc typically attached to rock or shell. For a detailed description of M. farcimen, see Fautin et al. (1989).

Cnidae. Spirocysts, basitrichs, microbasic $p$-mastigophores, microbasic amastigophores.

Distribution. Metridium farcimen was described by Brandt (1835) from Kamchatka, Russia. Specimens have since been collected throughout the North Pacific Ocean and we extend the range of the species from subtidal waters to 2,740 m, north to the Bering Sea and within the North Pacific from Mexico to Russia (Figure 33).

Taxonomic remarks. Fautin et al. (1989) described as a new species Metridium giganteum Fautin, Bucklin, and Hand, 1989, distinguishing it from the two other species found along the northeastern Pacific coast, M. senile (Linnaeus, 1761) and M. exile Hand, 1956. However, Fautin and Hand (2000) found several names that had previously been applied to this species: its valid name is M. farcimen (Brandt, 1835). 
Its great size and lobed oral disc make large specimens of Metridium farcimen among the most distinctive species of sea anemone in the North Pacific. However, small specimens of M. farcimen have been confused with and misidentified as M. senile in publication, and because of their similarities, it is not possible to determine which were the subject of some publications (Fautin \& Hand 2000). Specimens of M. farcimen can grow much larger than specimens of $M$. senile, which reach a maximum length of only $100 \mathrm{~mm}$ (Fautin et al. 1989). The oral disc of $M$. farcimen is divided into distinct stiffened lobes whereas the oral disc of $M$. senile is flaccid and the lobes are less distinct.

Material examined. See Appendix 14.

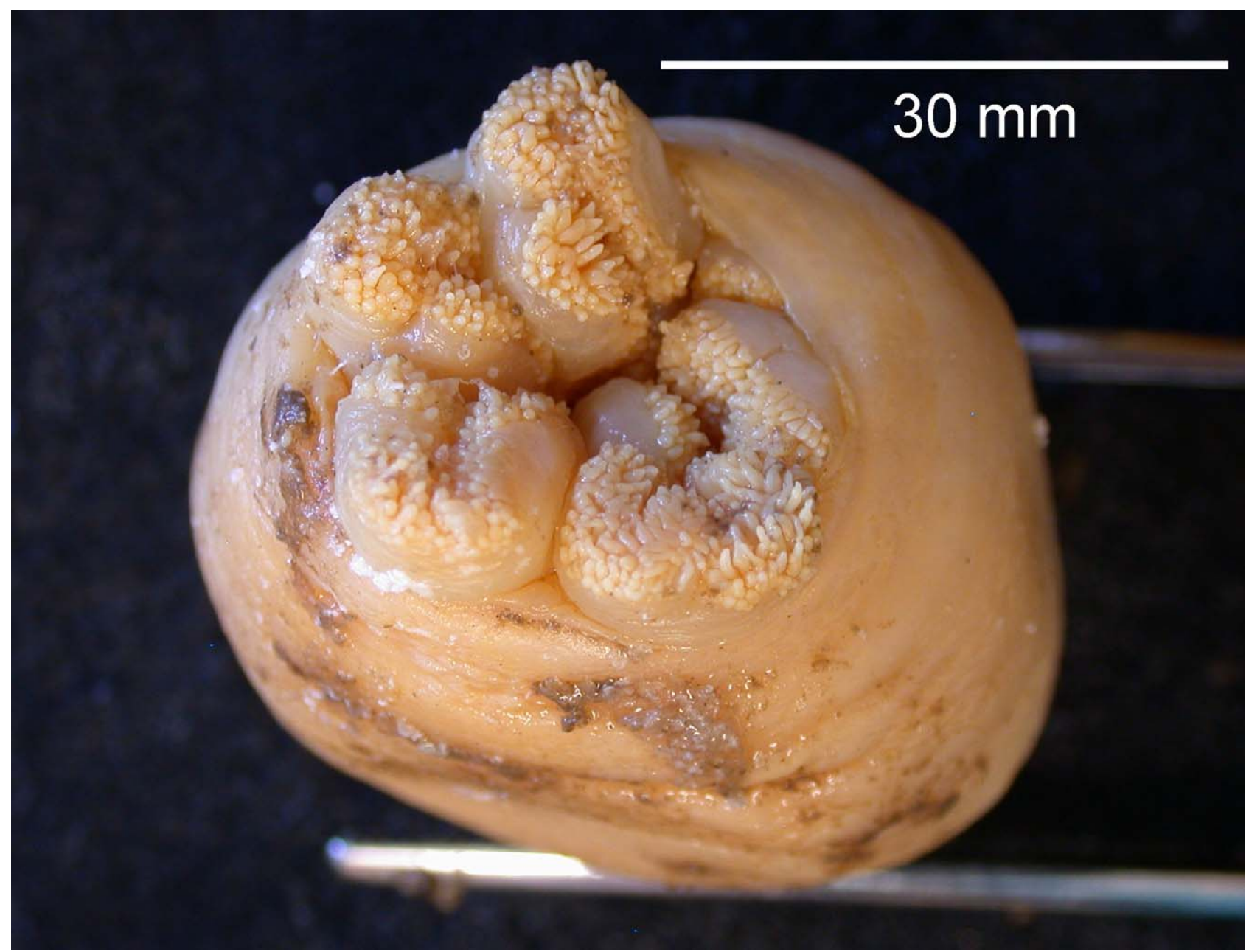

FIGURE 32. Oral view of Metridium farcimen showing stiffened lobes of oral disc (KUIZ 001436). 




FIGURE 33. Distribution of Metridium farcimen from Mexico to Russia.

\section{Family Sagartiidae Gosse, 1858}

\section{Genus Sagartiogeton Carlgren, 1924}

\section{Sagartiogeton californicus (Carlgren, 1940)}

(Figures 34-37, Table 5, Appendix 15)

Synonyms: see below

Body form and size. Column ectoderm tan or rose; in most specimens ectoderm sloughed off (likely caused by collection process), exposing mesoglea. Mesoglea of scapulus white, thick (about $1 \mathrm{~mm}$ ), and cartilaginous; that of scapus thin, and mesenterial insertions and purple endoderm of mesenteries (white in two specimens) apparent. Gametogenic tissue white, and filaments tan to purple. Purple endoderm and white gametogenic tissue make column appear purple and white spotted when ectoderm sloughed off (Figure 34). Sparse cinclides in distal part of scapus and near limbus.

Specimens short (about $3 \mathrm{~mm}$ long near mouth, $0.1 \mathrm{~mm}$ long at limbus) to approximately as tall as wide (to about $20 \mathrm{~mm}$ long), depending on contraction. Pedal disc typically wide; oral disc small and typically hidden along with bases of tentacles below contracted margin of column. Pedal disc circular or slightly oval, to diameter of 47 $\mathrm{mm}$. Oral disc (to about $14 \mathrm{~mm}$ diameter) much smaller than pedal disc.

Pedal disc. Pedal disc off-white to tan; in most specimens slightly transparent with mesenterial insertions visible. Wide, concave in most specimens, shape depending on substrate; attached to shells, rocks, or crab exoskeleton. Most specimens with fine debris attached to pedal disc, inferred to be from substrate. Some specimens with gastropod shell embossed on pedal disc. 




FIGURE 34. Two specimens of Sagartiogeton californicus showing variation in body form (on left SBMNH 83608; on right RBCM 988-00261-029).

TABLE 5. Cnida size and distribution of Sagartiogeton californicus. Because cnidae were measured from preserved specimens, the identity of $p$-mastigophores and amastigophores was unclear. ${ }^{*}$ Sparse.

\begin{tabular}{llll}
\hline Tissue and Cnida Type & Length $\mathbf{x}$ Width $(\boldsymbol{\mu m})$ & $\mathbf{n}$ & $\mathbf{N}$ \\
\hline Tentacles & & & \\
Gracile spirocysts (a) & $14.7-37.4(39.8) \times 2.0-4.5(4.9)$ & 45 & $3 / 3$ \\
Robust spirocysts (b) & $(16.6) 17.8-36.9 \times 4.2-7.5(8.8)$ & 40 & $3 / 3$ \\
Basitrichs (c) & $8.9-13.9(17.3) \times 1.5-2.3$ & 41 & $3 / 3$ \\
Basitrichs (d) & $17.0-29.3 \times 2.2-3.2(3.5)$ & 38 & $3 / 3$ \\
Microbasic amastigophores (e) & $17.9-31.5 \times 3.1-5.0$ & 38 & $3 / 3$ \\
Acontia & & & \\
Basitrichs* (f) & $11.2-17.3 \times 1.7-2.3$ & 23 & $4 / 4$ \\
Basitrichs (g) & $35.8-44.3 \times 2.9-4.1$ & 40 & $4 / 4$ \\
Microbasic amastigophores (h) & $55.1-70.1 \times(5.2) 5.5-7.1(7.5)$ & 40 & $4 / 4$ \\
Actinopharynx & & & 16 \\
Basitrichs* (i) & $10.5-15.0 \times 1.4-2.1$ & $3 / 3$ \\
Basitrichs (j) & $25.0-34.0 \times 2.8-3.2$ & 28 & $3 / 3$ \\
Microbasic amastigophores (k) & $23.9-35.2 \times 3.4-5.0$ & 41 & $3 / 3$ \\
Mesenterial Filaments & & & 34 \\
Basitrichs* (l) & $9.3-14.8(15.5) \times 1.5-2.3$ & $4 / 4$ \\
Microbasic $p$-mastigophores (m) & $9.6-14.7(16.9) \times 3.0-4.9$ & $3 / 4$ \\
Macrobasic $p$-mastigophores (n) & $(35.3) 41.4-61.2(66.1) \times 6.2-9.0$ & 10 & $1 / 4$ \\
Microbasic amastigophores (o) & $(17.2) 18.7-33.0(34.9) \times(3.0) 3.4-5.2(5.9)$ & 48 & $4 / 4$ \\
\hline
\end{tabular}


Oral disc and tentacles. Oral disc tan and smooth, mesenterial insertions may be visible. Approximately same shape as pedal disc (circular or slightly oval). In most specimens margin contracted so oral disc and bases of inner tentacles not visible.

Mouth approximately half oral disc diameter. Lips purple, slightly raised, radially furrowed. Position of two symmetrical siphonoglyphs evident externally by smaller lips and slightly lighter pigmentation.

About 200 dark purple to white tentacles; ectoderm of outer tentacles typically sloughed away, dark purple endoderm visible through transparent mesoglea. Conical; $1-8 \mathrm{~mm}$ long, taper from $0.3-1 \mathrm{~mm}$ at base to less than $0.1 \mathrm{~mm}$ at tip. Tentacles arrayed in six cycles near margin (fewer tentacles in small specimens). Exocoelic tentacles outermost; shorter than inner (endocoelic) tentacles.
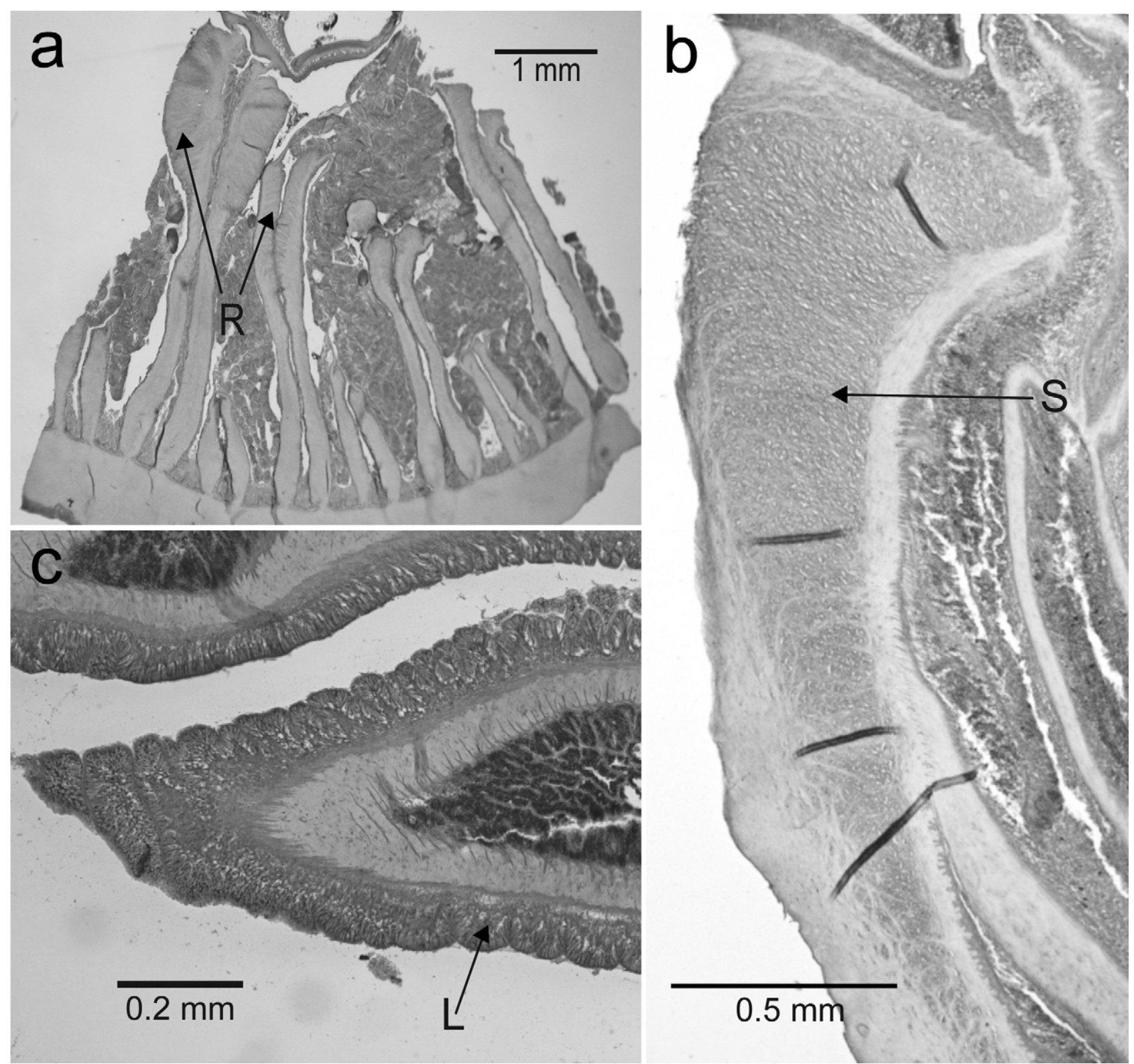

FIGURE 35. Sagartiogeton californicus. a. Mesenteries with large diffuse retractor muscles (R); b. well-developed mesogleal retractor muscle $(\mathrm{S})$; c. tentacle with ectodermal longitudinal musculature (L).

Internal anatomy. Actinopharynx dark purple; long in tall specimens, short in flat specimens. Each of two off-white siphonoglyphs attached to pair of directive mesenteries.

Mesenteries typically with purple endoderm (pink to white in some specimens). Arrayed in five cycles; smaller specimens with fewer cycles (three cycles in flat specimen with pedal disc diameter $8 \mathrm{~mm}$ ). All mesenteries, except some of youngest cycle, with filaments and gametogenic tissue. Mesenteries of first three cycles complete, with central stomata (see Arellano \& Fautin 2001). Mesenteries develop from proximal and distal end. Acontia salmon 
or off-white with small purple spots. Retractor muscles diffuse, may be lobed; poorly developed in young mesenteries, well developed in old mesenteries (Figure 35a). Parietobasilar muscles not apparent.

Mesogleal marginal sphincter muscle reticular, well developed, occupies most of mesoglea; separated from endoderm by thin strip of mesoglea (Figure 35b). Longitudinal musculature of tentacles ectodermal; circular muscles inferred to be endodermal (Figure 35c).

Cnidae. Gracile and robust spirocysts, basitrichs, microbasic p-mastigophores, microbasic amastigophores. Large macrobasic mastigophores (likely macrobasic $p$-mastigophores) were found in clusters in the mesenterial filaments of only one specimen of $S$. californicus; because discharged nematocysts were not observed, we are unable to determine for certain if they are macrobasic amastigophores or $p$-mastigophores. Sizes and distribution of cnidae given in Table 5; cnidae illustrated in Figure 36.
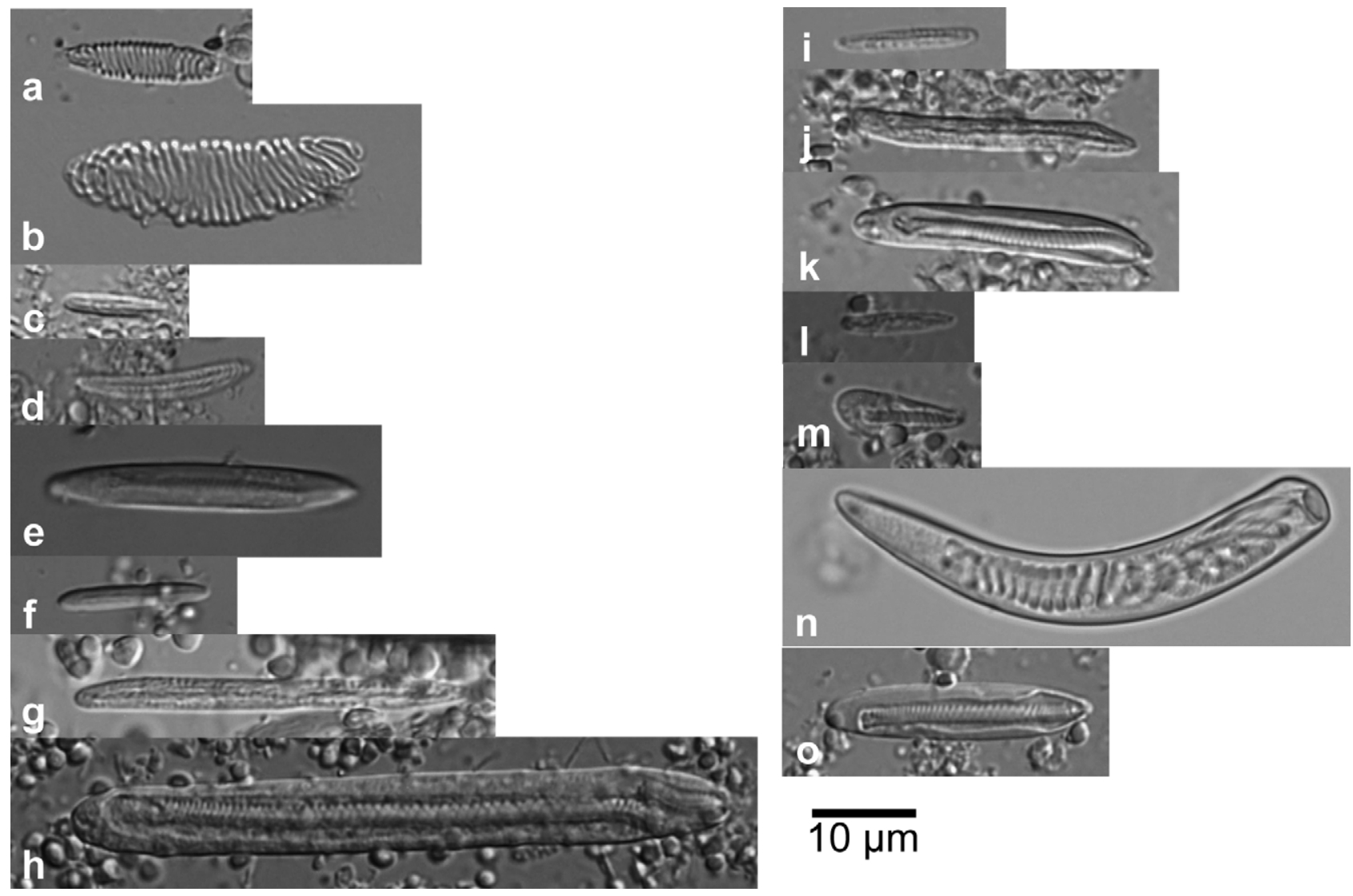

FIGURE 36. Cnidae of Sagartiogeton californicus; distribution and dimensions in Table 5. a. Gracile spirocyst; b. robust spirocyst; c. basitrich; d. basitrich; e. microbasic amastigophore; f. basitrich; g. basitrich; h. microbasic amastigophore; i. basitrich; j. basitrich; k. microbasic amastigophore; 1 . basitrich; m. microbasic $p$-mastigophore; n. macrobasic $p$-mastigophore; o. microbasic amastigophore.

Distribution. Sagartiogeton californicus occur from the northeastern Pacific from Mexico to British Columbia from depths of $73 \mathrm{~m}$ to at least 1,463 $\mathrm{m}$ (Figure 37).

Taxonomic remarks. The original description of Actinothoë californica Carlgren, 1940, lacks an illustration of the whole animal and many anatomical details. We were unable to locate specimens upon which Carlgren (1942) based his description in any of the natural history museums that (to our knowledge) have material Carlgren studied; therefore, we designate specimen KUIZ 001451, collected 26-Oct-1997 at 34.89-34.91 ${ }^{\circ} \mathrm{N}, 122.50-122.49^{\circ} \mathrm{W}$, $687 \mathrm{~m}$, as the name-bearing neotype of S. californicus. Article 75 of the International Code of Zoological Nomenclature (International Commission on Zoological Nomenclature 1999) stipulates that a neotype is to be designated only if "a name-bearing type is necessary to define the nominal taxon objectively ... not as an end in itself, or as a matter of curatorial routine."

The misidentification of specimen USNM 53337 by Cutress as Sagartiogeton californicus (below) illustrates the need to designate a neotype to anchor the species concept. The specimen that we designate as the neotype of Sagartiogeton californicus, KUIZ 001451, was collected nearest the type locality ( $\left.27^{\circ} 04^{\prime} \mathrm{N}, 111^{\circ} 54^{\prime} \mathrm{W}, 40 \mathrm{fm}\right)$ of those animals we examined. 


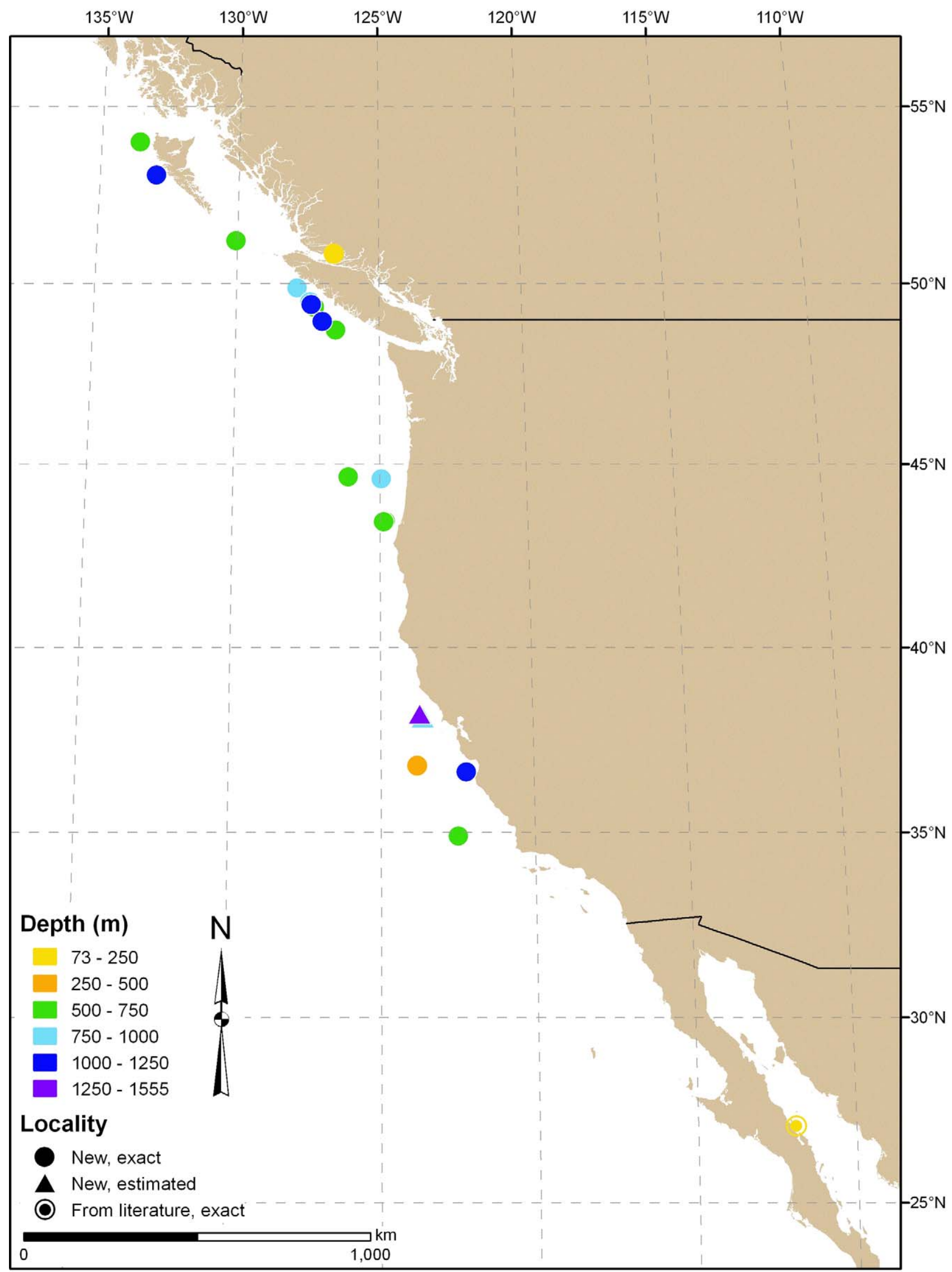

FIGURE 37. Distribution of Sagartiogeton californicus from Mexico to British Columbia. 
Specimen USNM 53337 differs from the specimens we examined in having a very long, lumpy scapulus with deep longitudinal furrows. It is larger ( $24 \mathrm{~mm}$ long, pedal disc $44 \mathrm{~mm}$ wide), and the older mesenteries are less muscular and more lobed than in the specimens Carlgren (1940) described and those we examined. The specimen lacks small basitrichs in the tentacles and possesses two sizes of microbasic amastigophores in the acontia, the smallest approximately $27 \mu \mathrm{m}$ long. This specimen is clearly a member of family Sagartiidae, but not Sagartiogeton californicus.

Carlgren (1949) and Kostina (1988) included both Actinothoe californica and Sagartiogeton californica in their inventories, seemingly considering them as separate species; both cited Carlgren (1940) as the author of both species, but Carlgren (1940) described only one species belonging to family Sagartiidae.

All of the specimens we examined that are cited in Appendix 15 agree well with published details except that Carlgren (1940) did not find small basitrichs in all tissues. These small nematocysts were sparse and easy to miss in specimens we examined. In addition, Carlgren (1940) reported much smaller microbasic amastigophores and basitrichs of the acontia than we found; however, size of these cnidae in acontia of members of Sagartiogeton, the genus into which Carlgren (1949) placed the species, vary greatly from specimen to specimen (Carlgren 1942). Due to similarities in location, depth, and morphology, we have identified as S. californicus the specimens that we examined. Although the external anatomy of this species varies, cnidae and internal anatomy of specimens are consistent.

The only other species of Sagartiogeton recorded from the Pacific Ocean, Sagartiogeton erythraios Zelnio, Rodriguez, and Daly, 2009, occurs in the southwestern Pacific to depths of 2,620 m. It can be distinguished from $S$. californicus by cnidae differences, in having fewer mesenteries and tentacles ( 3 cycles of mesenteries and 48 tentacles), no cinclides, and a column with a cuticle and papillae. The combination of a reticular marginal sphincter muscle nearly as wide as the mesoglea, retractor muscles that are often lobed, and central stomata differentiate $S$. californicus from S. erythraios, and its other congeners, all of which occur in the northern Atlantic Ocean.

Material examined. See Appendix 15.

Differential diagnosis. Sagartiogeton californicus can be distinguished from its congeners by its combination of: column with no cuticle or papillae; about 200 tentacles; five cycles of mesenteries; central stomata; cinclides; wide reticular marginal sphincter muscle; retractor muscles that are often lobed.

\section{Discussion}

Ten (71\%) of the 14 deep-sea species of Actiniaria and Corallimorpharia (sea anemones sensu lato) we studied appear endemic to the North Pacific Ocean; however, only the genus Paraphelliactis is endemic, and none of the families are. This is the pattern found by Vinogradova (1959) for many deep-sea taxa and Rodríguez et al. (2007) for anemones of the Southern Ocean: at the species level animals tend to be confined to one ocean, but at the generic and family levels they are widespread. Of the 13 genera we studied from the northeastern Pacific Ocean, 8 $(62 \%)$ are also found in the Southern Ocean and 12 (92\%) in the Atlantic Ocean. All the families from the northeastern Pacific Ocean are found in the Southern and Atlantic Oceans as well. The deep-sea anemone fauna of the Indian Ocean is too poorly known to be meaningfully compared.

Seven $(50 \%)$ of the species we identified have been found only in the northeastern Pacific (Corallimorphus pilatus, Corallimorphus denhartogi, Anthosactis nomados, Bolocera kensmithi n. sp., Paraphelliactis pabista, Sagartiogeton californicus, and Sicyonis careyi $\mathrm{n}$. sp.). These are the species most likely to be adversely affected if the OMZ spreads. Of the remaining seven, three are also known from the Southern Ocean and likely occur all along the eastern Pacific (Actinauge verrillii, Bathyphellia australis and Actinoscyphia groendyki n. sp.), one is known from the Atlantic Ocean (Monactis vestita), and three are also known from the northwestern Pacific (Actinostola faeculenta, Liponema brevicorne, and Metridium farcimen).

Species with the widest distributions occur below 2,000 m: Actinauge verrillii to 4,250 m, Actinoscyphia groendyki $\mathrm{n}$. sp. to at least $3,819 \mathrm{~m}$, Actinostola faeculenta to $2,265 \mathrm{~m}$, Bathyphellia australis to $4,575 \mathrm{~m}$, Liponema brevicorne to 4,134 m, Metridium farcimen to 2,740 m, and Monactis vestita to 5,320 m.

However, great depth does not always correlate with broad occurrence: Corallimorphus denhartogi (to 4,292 $\mathrm{m}$ ), Anthosactis nomados (to 4,325 m), Bolocera kensmithi n. sp. (to 4,100 m), Paraphelliactis pabista (to 4,100 $\mathrm{m}$ ), and Sicyonis careyi n. sp. (to 3,700 m) appear endemic to the northeastern Pacific. The distribution of 
Anthosactis nomados is likely restricted by its symbiosis with the scaphopod Fissidentalium actiniophorum, which is known only from the northeastern Pacific (Shimek 1997, White et al. 1999). Species that mostly occur above 2,000 m (Corallimorphus pilatus from 250 to 2,026 m, and Sagartiogeton californicus from 73 to at least 1,463 m) appear endemic to the northeastern Pacific. The growing OMZ poses the biggest threat to the four species endemic to the northeastern Pacific Ocean that occur within the depth range of the OMZ and have restricted geographical ranges (Corallimorphus pilatus, Anthosactis nomados, Sagartiogeton californicus, and Sicyonis careyi $\mathrm{n}$. sp.).

The similarity of deep-sea faunas in all oceans, is most apparent in groups whose members are good dispersers: ostracods, isopods, and nematodes are poor dispersers and typically have limited distributions, whereas foraminiferans have easily transported larvae and are typically widespread (Brandt et al. 2007). Future work on dispersal of the deep-sea anemones of the northeastern Pacific may help explain why some species are more widespread than others that occur at similar depths.

\section{Acknowledgments}

Funding was provided by the Department of Ecology and Evolutionary Biology, KU (University of Kansas) (WEEL), the Panorama Society Small Grant Program, Biodiversity Institute, KU (WEEL), grant EF-0531779 from the National Science Foundation in the program Assembling the Tree of Life (DGF), and an award from Fisheries and Oceans Canada (DGF). We acknowledge James Boutillier of the Pacific Biological Station, British Columbia, and Jeffrey Drazen of MBARI, for providing us specimens of deep-sea anemones. We thank Moretta Frederick (RBCM), Robert Van Syoc and Elizabeth Kools (CAS), and Paul Valentich Scott and F.G. Hochberg (SBMNH) for their help and hospitality while we examined specimens from their collections. We gratefully appreciate the Museum National d'Histoire Naturelle, RBCM, SBMNH, Swedish Museum of Natural History, and the USNM for loaning us specimens for our comparative studies. We thank Andrea Crowther (KUIZ) for her assistance with accessioning and cataloging specimens. We are also indebted to Shawn Saving, from the Kansas Geological Survey, KU, for guidance on creating species distribution maps. We thank Marymegan Daly, Estefanía Rodríguez, and one anonymous reviewer for their insightful comments on an earlier version of our manuscript.

\section{References}

Arellano, S.M. \& Fautin, D.G. (2001) Redescription and range extension of the sea anemone Exocoelactis actinostoloides (Wassilieff, 1908), with revision of genus Exocoelactis (Cnidaria, Anthozoa, Actiniaria). Zoosystema, 23(4), 645-657.

de Blainville, H.M. (1824) Metridium. Dictionnaire des Sciences Naturelles. Vol. 30. F. G. Levrault, Strasbourg, France, 470 pp.

Braby, C.E., Pearse, V.B., Bain, B.A. \& Vrijenhoek, R.C. (2009) Pycnogonid-cnidarian trophic interactions in the deep Monterey Submarine Canyon. Invertebrate Biology, 128(4), 359-363.

Brandt, A., Gooday, A.J., Brandão, S.N., Brix, S., Brökeland, W., Cedhagen, T., Choudhury, M., Cornelius, N., Danis, B., De Mesel, I., et al. (2007) First insights into the biodiversity and biogeography of the Southern Ocean deep sea. Nature, 447, 307-311.

Brandt, J.F. (1835) Prodromus Descriptionis Animalium AB H. Mertensio in Orbis Terrarum Circumnavigatione Observatorum. Vol. 1. Sumptibus Academiae, Petropoli, 75 pp.

Broecker, W.S. (1991) The great ocean conveyor. Oceanography, 4(2), 79-89.

Carlgren, O. (1893) Studien über nordische Actinien. Kungliga Svenska Vetenskapsakademiens Handlingar, 25(10), 1-148.

Carlgren, O. (1921) Actiniaria I. Danish Ingolf-Expedition, 5, 1-241.

Carlgren, O. (1928a) Actiniaria der Deutschen Tiefsee-Expedition. Wissenschaftliche Ergebnisse der Deutschen TiefseeExpedition auf dem Dampfer "Valdivia" 1898-1899, 22(4), 125-266.

Carlgren, O. (1928b) Ceriantharier, Zoantharier och Actiniarier. Meddelelser om Grønland, supplement 23, 253-308.

Carlgren, O. (1932) Die Ceriantharien, Zoantharien und Actiniarien des arktischen Gebietes. In: Römer, F, Schaudinn, F, Brauer, A \& Arndt, W (Eds), Eine Zusammenstellung der arktischen Tierformen mit besonderer Berücksichtigung des Spitzbergen-Gebietes auf Grund der Ergebnisse der Deutschen Expedition in das Nördliche Eismeer im Jahre 1898. Vol 6. Gustav Fisher, Jena, Germany, pp. 255-266.

Carlgren, O. (1934a) Ceriantharia, Zoantharia and Actiniaria from the "Michael Sars" North Atlantic Deep-sea Expedition 1910. Report on the Scientific Results of the "Michael Sars" North Atlantic Deep-Sea Expedition 1910, 5(6), 1-27.

Carlgren, O. (1934b) Zur Revision der Actiniarien. Arkiv für Zoologi, 26A(18), 1-36.

Carlgren, O. (1940) Eastern Pacific Expeditions of the New York Zoological Society XIX. Actiniaria from the Gulf of California. Zoologica, 25(2), 211-219.

Carlgren, O. (1942) Actiniaria II. Danish Ingolf-Expedition, 5(12), 1-92. 
Carlgren, O. (1949) A survey of the Ptychodactiaria, Corallimorpharia, and Actiniaria. Kungliga Svenska Vetenskapsakademiens Handlingar, 1(1), 1-121.

Carlgren, O. (1951) The actinian fauna of the Gulf of California. Proceedings of the United States National Museum, 101, 415-449.

Carlgren, O. (1956) Actiniaria from depths exceeding 6000 meters. Galathea Reports, 2, 9-16.

Carney, R.S. \& Carey, A.G. (1982) Distribution and diversity of holothuroids (Echinodermata) on Cascadia Basin and Tufts Abyssal Plain. Deep Sea Research Part A. Oceanographic Research Papers, 29(5A), 597-607.

Chan, F., Barth, J.A., Lubchenco, J., Kirincich, A., Weeks, H., Peterson, W.T. \& Menge, B.A. (2008) Emergence of anoxia in the California Current Large Marine Ecosystem. Science, 319, 920.

Cressey, D. (2010) Marine biology: Out of the Blue. Nature, 467, 514-515.

Danielssen, D.C. (1890) Actinida. Den Norske Nordhavs-Expedition 1876-1878. Zoologi. Grøndahl and Søn, Christiania, Norway, 184 pp.

Deacon, G.E.R. (1982) Physical and biological zonation in the Southern Ocean. Deep Sea Research Part A. Oceanographic Research Papers, 29(1), 1-15.

Doumenc, D. (1975) Actinies bathyales et abyssales de l'océan Atlantique nord familles des Hormathiidae (genres Paracalliactis et Phelliactis) et des Actinostolidae (genres Actinoscyphia et Sicyonis). Bulletin du Muséum National d'Histoire Naturelle (Paris), 197(3), 157-204.

Dunn, D.F. (1982) Paraphelliactis pabista, a new species of hormathiid sea anemone from abyssal northeastern Pacific waters (Coelenterata: Actiniaria). Syesis, 15, 51-56.

Dunn, D.F. (1983) Some Antarctic and sub-Antarctic sea anemones (Coelenterata: Ptychodactiaria and Actiniaria). Antarctic Research Series, 39, 1-67.

Dunn, D.F. \& Bakus, G.L. (1977) Redescription and ecology of Liponema brevicornis (McMurrich, 1893), with definition of the family Liponematidae (Coelenterata, Actiniaria). Astarte, 10, 77-85.

Ekman, S. (1953) Zoogeography of the Sea. Sidgwick and Jackson Limited, London, England, 417 pp.

Fautin, D.G. (1984) More Antarctic and Subantarctic sea anemones (Coelenterata: Corallimorpharia and Actiniaria). Antarctic Research Series, 41, 1-42.

Fautin, D.G. (1997) Cnidarian reproduction: assumptions and their implications. In: den Hartog, J. C. (Ed), Proceedings of the 6th International Conference on Coelenterate Biology. Nationaal Natuurhistorisch Museum, Leiden, the Netherlands, pp. $151-162$.

Fautin, D.G. (2011) Hexacorallians of the World. Available from: http://geoportal.kgs.ku.edu/hexacoral/anemone2/index.cfm [Consulted most recently October 2011].

Fautin, D.G. \& Barber, B.R. (1999) Maractis rimicarivora, a new genus and species of sea anemone (Cnidaria: Anthozoa: Actiniaria: Actinostolidae) from an Atlantic hydrothermal vent. Proceedings of the Biological Society of Washington, 112(3), 624-631.

Fautin, D.G., Bucklin, A. \& Hand, C. (1989) Systematics of sea anemones belonging to genus Metridium (Coelenterata: Actiniaria), with a description of M. giganteum new species. Wasmann Journal of Biology, 47(1-2), 77-85.

Fautin, D.G., Daly, M. \& Cappola, V. (2005) Sea anemones (Cnidaria: Actiniaria) of the Faroe Islands: a preliminary list and biogeographic context. Annales Societatis Scientiarum Faroensis, 41, 77-87.

Fautin, D.G. \& Hand, C. (2000) Metridium farcimen, the valid name of a common North Pacific sea anemone (Cnidaria: Actiniaria: Acontiaria). Proceedings of the Biological Society of Washington, 113(4), 1151-1161.

Fautin, D.G. \& Hand, C. (2007) Actiniaria. In: Carlton J. T. (Ed), The Light and Smith Manual: Intertidal Invertebrates from Central California to Oregon. $4^{\text {th }}$ ed. University of California Press, Los Angeles, California, pp. 134-145.

Fautin, D.G. \& Hessler, R.R. (1989) Marianactis bythios, a new genus and species of actinostolid sea anemone (Coelenterata: Actiniaria) from the Mariana vents. Proceedings of the Biological Society of Washington, 102(4), 815-825.

Fautin, D.G., White, T.R. \& Pearson, K.E. (2002) Two new species of deep-water Corallimorpharia (Cnidaria: Anthozoa) from the northeast Pacific, Corallimorphus denhartogi and C. pilatus. Pacific Science, 56(2), 113-124.

Gewin, V. (2010) Dead in the water. Nature, 466, 812-814. doi:10.1038/466812a.

Gosse, P.H. (1858) Synopsis of the families, genera, and species of the British Actiniae. Annals and Magazine of Natural History, 1, 414-419.

Gosse, P.H. (1860) A History of the British Sea-Anemones and Corals. Van Voorst, London, England, 362 pp.

Gotshall, D. (1994) Guide to Marine Invertebrates: Alaska to Baja California. Sea Challengers, Monterey, California, 112 pp.

Gravier, C. (1918) Note préliminaire sur les hexactiniaires recueillis au cours des croisières de la Princesse-Alice et de l'Hirondelle de 1888 à 1913 inclusivement. Bulletin de l'Institut Océanographique (Monaco), 346, 1-24.

Häussermann, V. (2004) The sea anemone genus Actinostola (Verrill 1883): variability and utility of traditional taxonomic features, and a re-description of Actinostola chilensis (McMurrich 1904). Polar Biology, 28, 26-38.

Häussermann, V. (2005) The sea anemone genus Actinostola Verrill 1883: variability and utility of traditional taxonomic features, and a re-description of Actinostola chilensis McMurrich 1904. Polar Biology, 28, 338-350.

Hand, C. (1956, for 1955) The sea anemones of central California Part III. The acontiarian anemones. Wasmann Journal of Biology, 13(2), 189-251.

Hertwig, R. (1882) Die Actinien der Challenger Expedition. Gustav Fischer, Jena, Germany, 119 pp.

Hertwig, R. (1888) Report on the Actiniaria dredged by H.M.S. Challenger during the years 1873-1876 [Supplement]. Report on the Scientific Results of the Voyage of the H.M.S. Challenger during the years 1873-76 (Zoology), 26(3), 1-56.

Humason, G.L. (1967) Animal Tissue Techniques. W.H. Freeman, San Francisco, California, 569 pp.

International Commission on Zoological Nomenclature (1999) International Code of Zoological Nomenclature. $4^{\text {th }}$ ed. The 
International Trust for Zoological Nomenclature, London, United Kingdom, 306 pp.

Johnston, G. (1832) Illustrations in British Zoology. Magazine of Natural History, 5, 163-164.

Kostina, E.E. (1988) Biogeographical characteristics of sea anemones of the Pacific boreal region [in Russian with English abstract]. Biologiya Morya, 3, 14-21.

Kramer, A. \& Francis, L. (2004) Predation resistance and nematocyst scaling for Metridium senile and M. farcimen. Biological Bulletin, 207, 130-140.

Linnaeus, C. (1761) Fauna Svecica. Laurentii Salvii, Stockholm, Sweden, 578 pp.

McCauley, J.E. \& Carey, A.G. (1967) Echinoidea of Oregon. Journal of the Fisheries Research Board of Canada, 24(6), 13851401.

McMurrich, J.P. (1893) Report on the Actiniae collected by the United States Fish Commission Steamer Albatross during the winter of 1887-1888. Proceedings of the United States National Museum, 16(930), 119-216.

McMurrich, J.P. (1904) The Actiniae of the Plate collection. Zoologische Jahrbucher, 6[suppl], 215-306.

Milne-Edwards, H. \& Haime, J. (1849) Recherches sur les polypiers, cinquiéme mémoire. Monographie des oculinides. Annales des Sciences Naturelles, 13, 63-110.

Moseley, H.N. (1877) On new forms of Actiniaria dredged in the deep sea; with a description of certain pelagic surfaceswimming species. Transactions of the Linnean Society (London), 1, 295-305.

National Geophysical Data Center, National Oceanic and Atmospheric Administration, U.S. Dept. of Commerce (2006) ETOPO2v2 Global Gridded 2-minute Database. Available from: http://www.ngdc.noaa.gov/mgg/global/etopo2.html [Consulted most recently Dec. 2010].

Pax, F. (1909) Die Aktinien der ostafrikanischen Inseln. In: Voeltzkow, A. (Ed), Reise in Ostafrika in den Jahren 1903-1905. 2 : pp. 399-418.

Pax, F. (1922) Diagnosen neuer Actiniarien aus der Ausbeute der Deutschen (1901-1903) und der Französischen (1908-1910) Südpolar-Expedition. Zoologischer Anzeiger, 54(3/4), 72-92.

Rafinesque, C.S. (1815) Analyse de la Nature ou Tableau de l'Univers et des Corps Organisés. C. S. Rafinesque, Palerme, Italy, $224 \mathrm{pp}$.

Riemann-Zürneck, K. (1973) Actiniaria des Südwestatlantik. I. Hormathiidae. Helgoländer Wissenschaftliche Meeresuntersuchungen, 25, 273-325.

Riemann-Zürneck, K. (1978) Actiniaria des Südwestatlantik. IV. Actinostola crassicornis (Hertwig, 1882) mit einer Diskission verwandter Arten. Helgoländer Wissenschaftliche Meeresuntersuchungen, 25, 273-325.

Riemann-Zürneck, K. (1986) On some abyssal sea anemones of the North Atlantic (Actiniaria: Hormathiidae). Mitteilungen aus dem Hamburgischen Zoologischen Museum Institut, 83, 7-29.

Riemann-Zürneck, K. (1991) A new species of Sicyonis (Actiniaria: Actinostolidae) from the abyssal NE Atlantic. Mitteilungen aus dem Hamburgischen Zoologischen Museum Institut, 88, 7-15.

Riemann-Zürneck, K. (1994) Taxonomy and ecological aspects of the Subarctic sea anemones Hormathia digitata, Hormathia nodosa, and Allantactis parasitica (Coelenterata, Actiniaria). Ophelia, 39(3), 197-224.

Riemann-Zürneck, K. (1997) The deep-sea anemones Bathyphellia margaritacea and Daontesia porcupina sp. nov. with comments on the family Bathyphelliidae. Journal of the Marine Biological Association of the United Kingdom, 77, 361-374.

Rodríguez, E., López-González, P.J. \& Gili, J.M. (2007) Biogeography of Antarctic sea anemones (Anthozoa: Actiniaria): what do they tell us about the origin of the Antarctic benthic fauna? Deep-Sea Research Part II, 54, 1876-1904.

Sanamyan, N.P., Cherniaev, E.S. \& Sanamyan, K.E. (2009) Bathyphellia margaritacea (Cnidaria: Actiniaria): the most northern species in the world. Polar Biology, 32, 1245-1250.

Sanamyan, N.P. \& Sanamyan, K.E. (2007) Deep-water Actiniaria from East Pacific hydrothermal vents and cold seeps. Invertebrate Zoology, 4(1), 83-102.

Shimek, R.L. (1997) A new species of eastern Pacific Fissidentalium (Mollusca: Scaphopoda) with a symbiotic sea anemone. Veliger, 40(2), 178-191.

Simon, J.A. (1892) Ein Beitrag zur Anatomie und Systematik der Hexactinien. Druck von Val. Hvfling, München, Germany, $106 \mathrm{pp}$.

Smith, K.L., Kaufmann, R.S. \& Baldwin, R.J. (1994) Coupling of near-bottom pelagic and benthic processes at abyssal depths in the eastern North Pacific Ocean. Limnology and Oceanography, 39(5), 1101-1118.

Stephenson, T.A. (1918) On certain Actiniaria collected off Ireland by the Irish Fisheries Department, during the years of 1899 1913. Proceedings of the Royal Irish Academy, 34B(7), 106-164.

Stephenson, T.A. (1920) On the classification of Actiniaria. Part I. -- Forms with acontia and forms with a mesogloeal sphincter. Quarterly Journal of Microscopical Science, 64(256), 425-574.

Studer, T. (1879) Zweite Abtheilung der Anthozoa polyactinia, welche während der Reise S. M. S. Corvette Gazelle um die Erde gesammelt wurden. Monatsberichte der könglich preussischen Akademie der Wissenschaften zu Berlin, 1878, 524-550.

Tilesius, G. T. (1809) De nova Actiniarum specie gigantean, Kamtschatica. Memoires de l'Académie Impériale des Sciences de St. Pétersbourg, 1, 388-422.

Verrill, A.E. (1882) Notice of the remarkable marine fauna occupying the outer banks off the southern coast of New England, No. 4. American Journal of Science and Arts, 23, 216-225.

Verrill, A.E. (1883) Reports on the Anthozoa, and on some additional species dredged by the "Blake" in 1877-1879, and by the U. S. Fish Commission Steamer "Fish Hawk" in 1880-82. Bulletin of the Museum of Comparative Zoology (Harvard University), 11(1), 1-72. 
Vinogradova, N.G. (1959) The zoogeographical distribution of the deep-water bottom fauna in the abyssal zone of the ocean. Deep-Sea Research, 5, 205-208.

White, T.R., Wakefield Pagels, A.K. \& Fautin, D.G. (1999) Abyssal sea anemones (Cnidaria: Actiniaria) of the northeast Pacific symbiotic with molluscs: Anthosactis nomados, a new species, and Monactis vestita (Gravier, 1918). Proceedings of the Biological Society of Washington, 112(4), 637-651.

Zamponi, M.O. \& Acũna, F. H. (1992) Sobre las caracteristicas gonadales de Monactis vestita (Gravier, 1918), Sensu RiemannZürneck, 1986 (Actiniaria, Hormathiidae). Iheringia (Porte Alegre), 72, 151-152.

Zelnio, K.A., Rodriguez, E. \& Daly, M. (2009) Hexacorals (Anthozoa: Actiniaria, Zoanthidea) from hydrothermal vents in the south-western Pacific. Marine Biology Research, 5, 547-571.

APPENDIX 1. Sources of locality information.

\begin{tabular}{llll}
\hline $\mathbf{1}$ & Specimens examined in this study & $\mathbf{1 1}$ & Sanamyan and Sanamyan 2007 \\
$\mathbf{2}$ & Fautin et al. 2002 & $\mathbf{1 2}$ & Dunn 1982 \\
$\mathbf{3}$ & Fautin 1984 & $\mathbf{1 3}$ & Dunn and Bakus 1977 \\
$\mathbf{4}$ & White et al. 1999 & $\mathbf{1 4}$ & Braby et al. 2009 \\
$\mathbf{5}$ & McMurrich 1893 & $\mathbf{1 5}$ & Carlgren 1951 \\
$\mathbf{6}$ & Dunn 1983 & $\mathbf{1 6}$ & Fautin et al. 1989 \\
$\mathbf{7}$ & Fautin 1997 & $\mathbf{1 7}$ & Kramer and Francis 2004 \\
$\mathbf{8}$ & Riemann-Zürneck 1986 & $\mathbf{1 8}$ & Brandt 1835 \\
$\mathbf{9}$ & Gravier 1918 & $\mathbf{1 9}$ & Tilesius 1809 \\
$\mathbf{1 0}$ & Fautin et al. 2005 & $\mathbf{2 0}$ & Carlgren 1940 \\
\hline
\end{tabular}




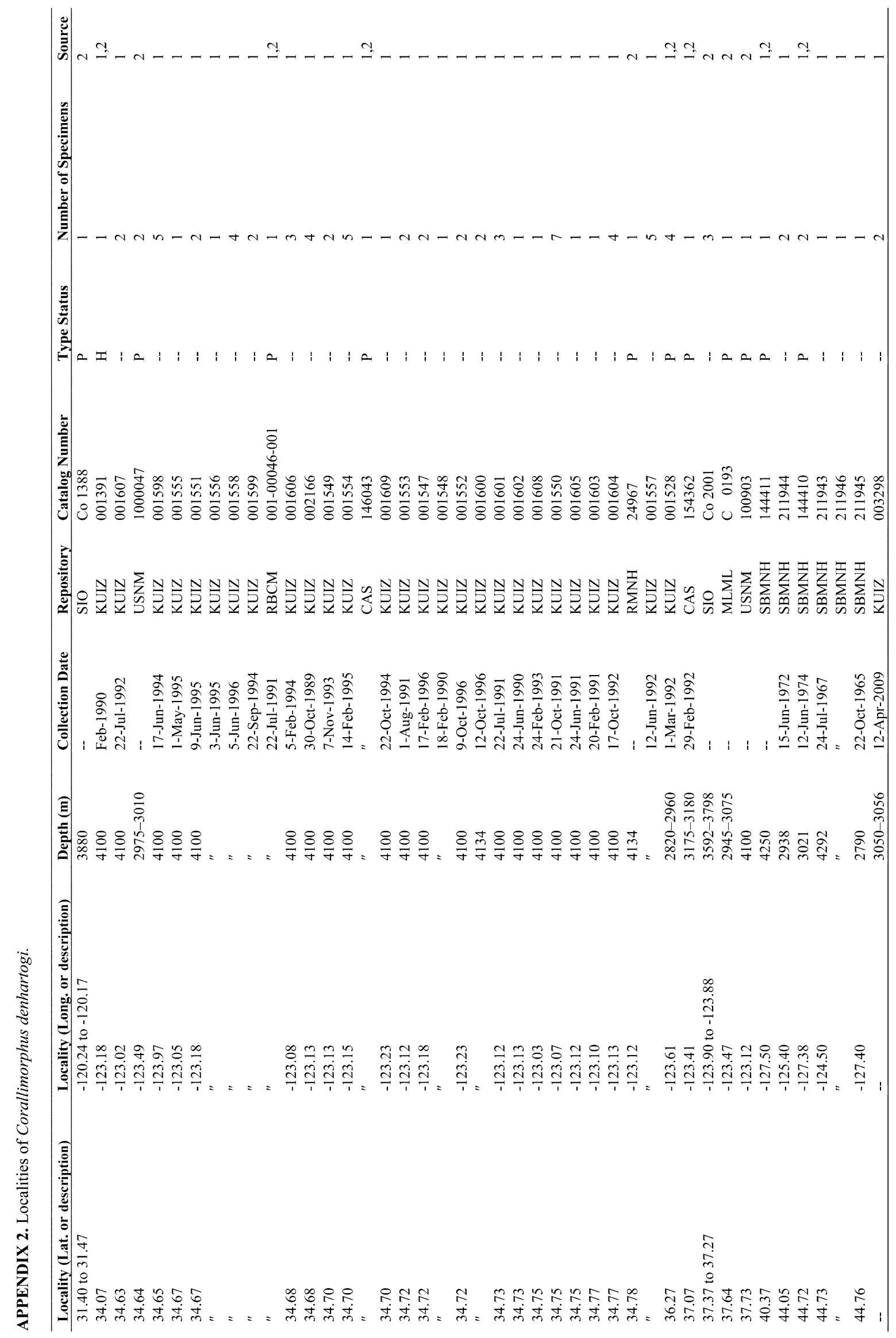




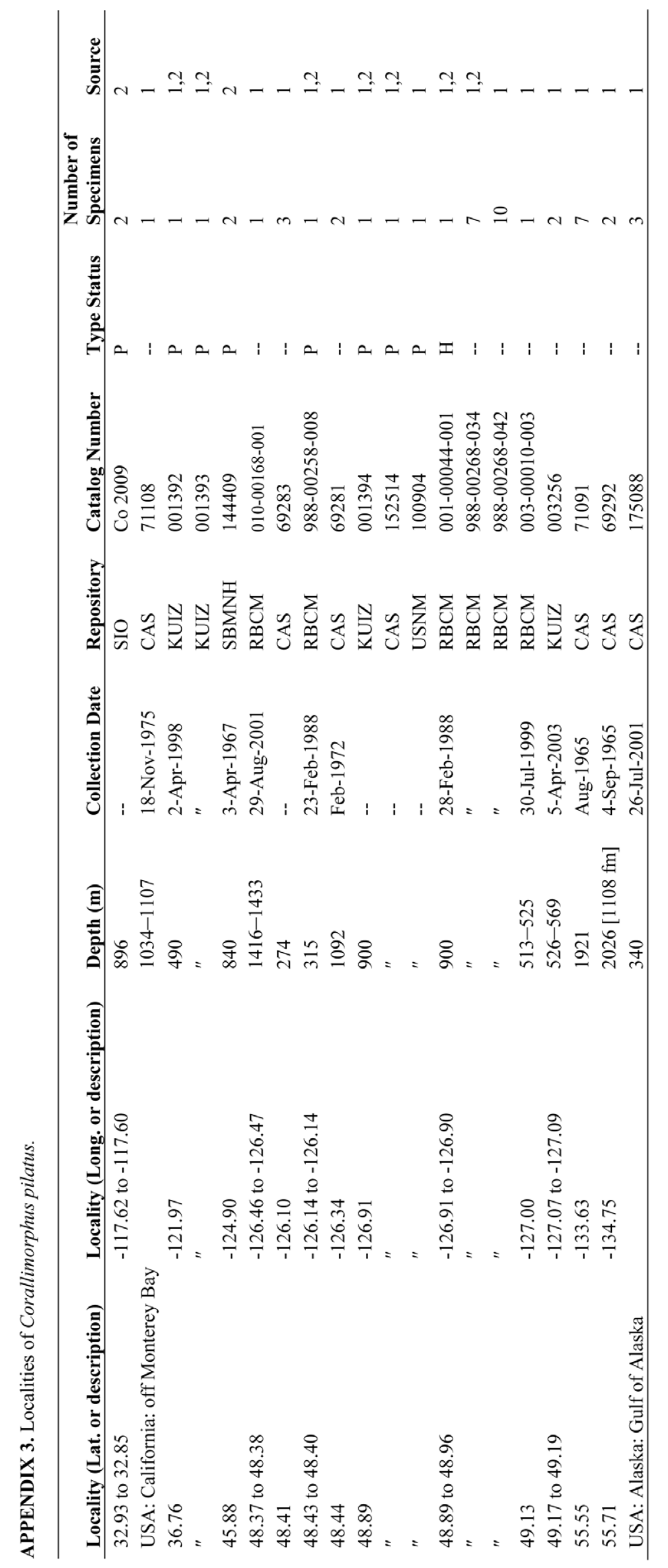




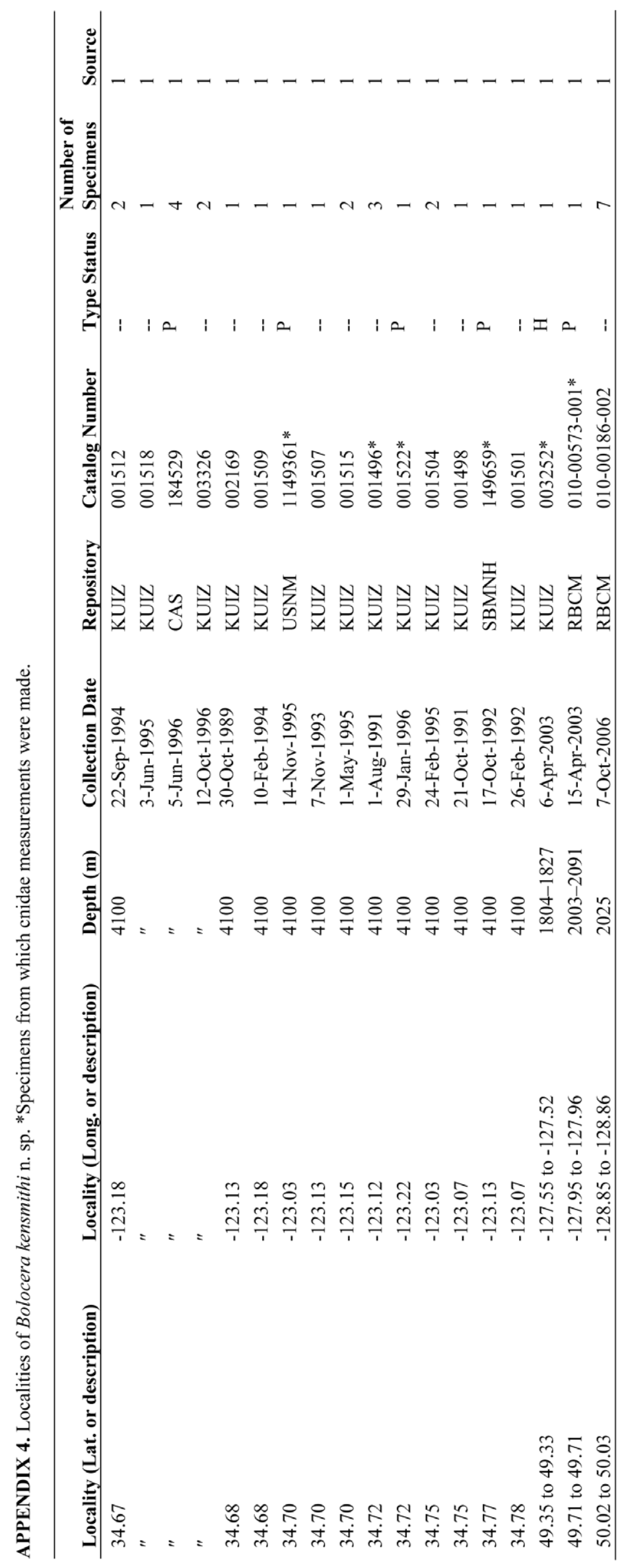









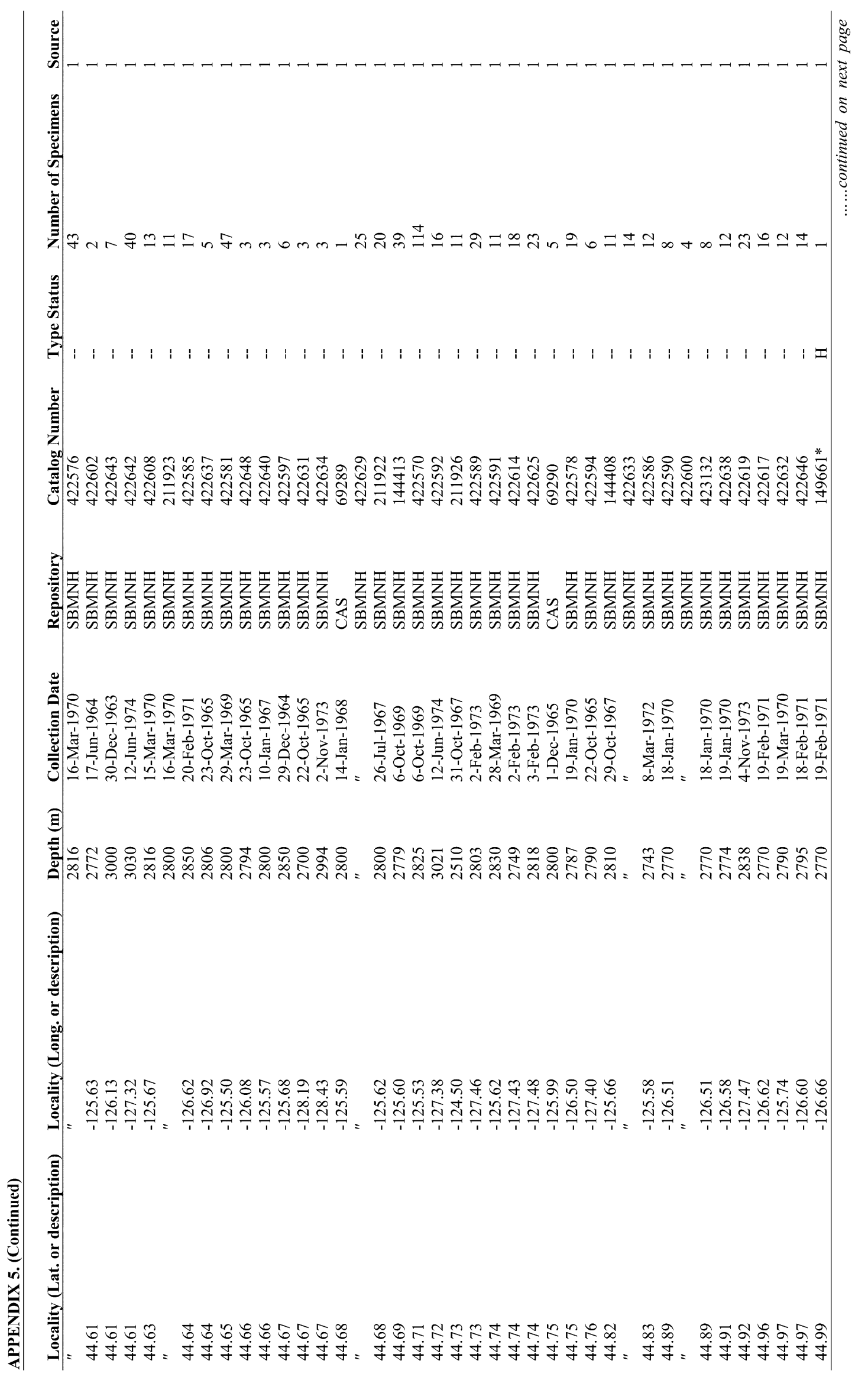




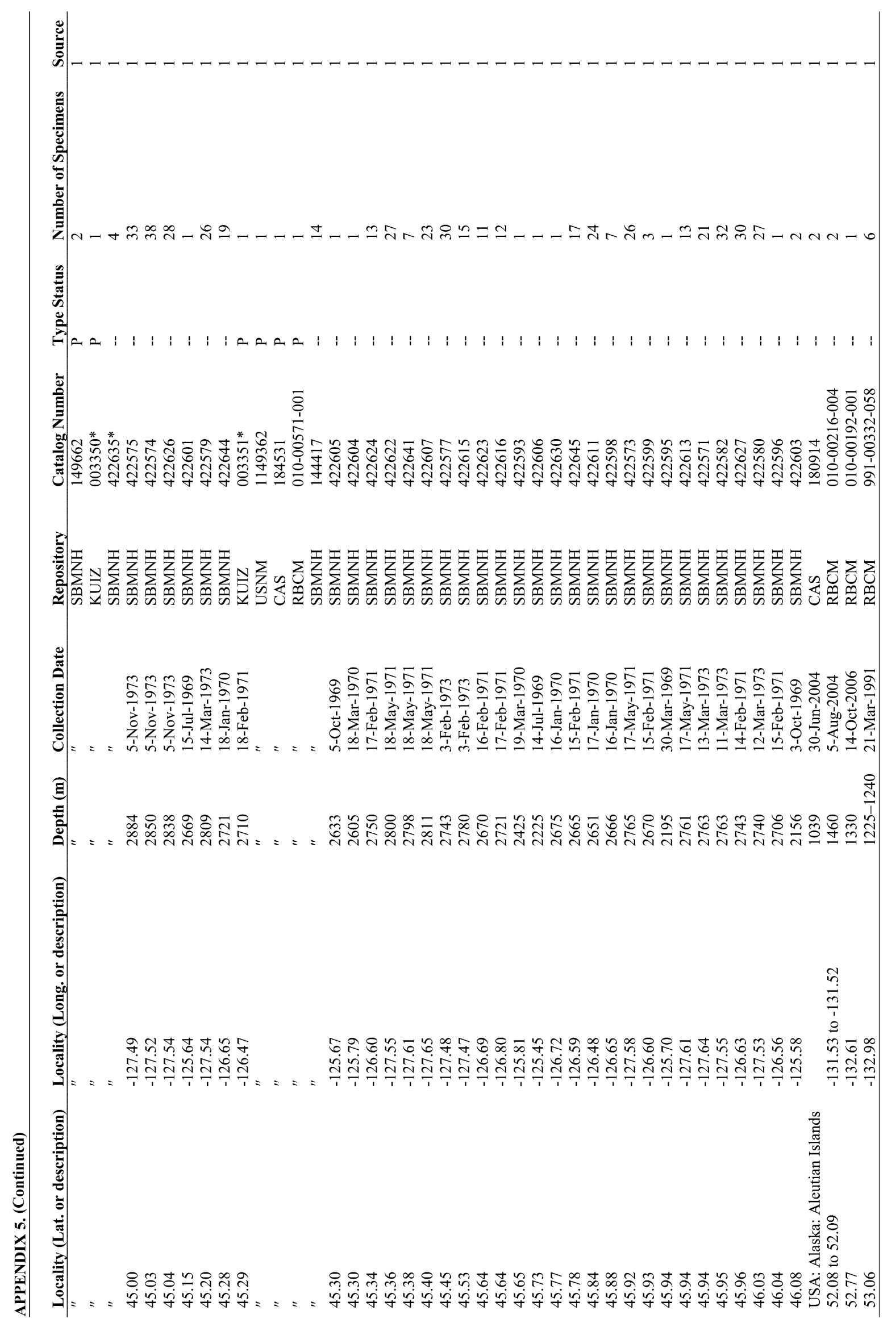




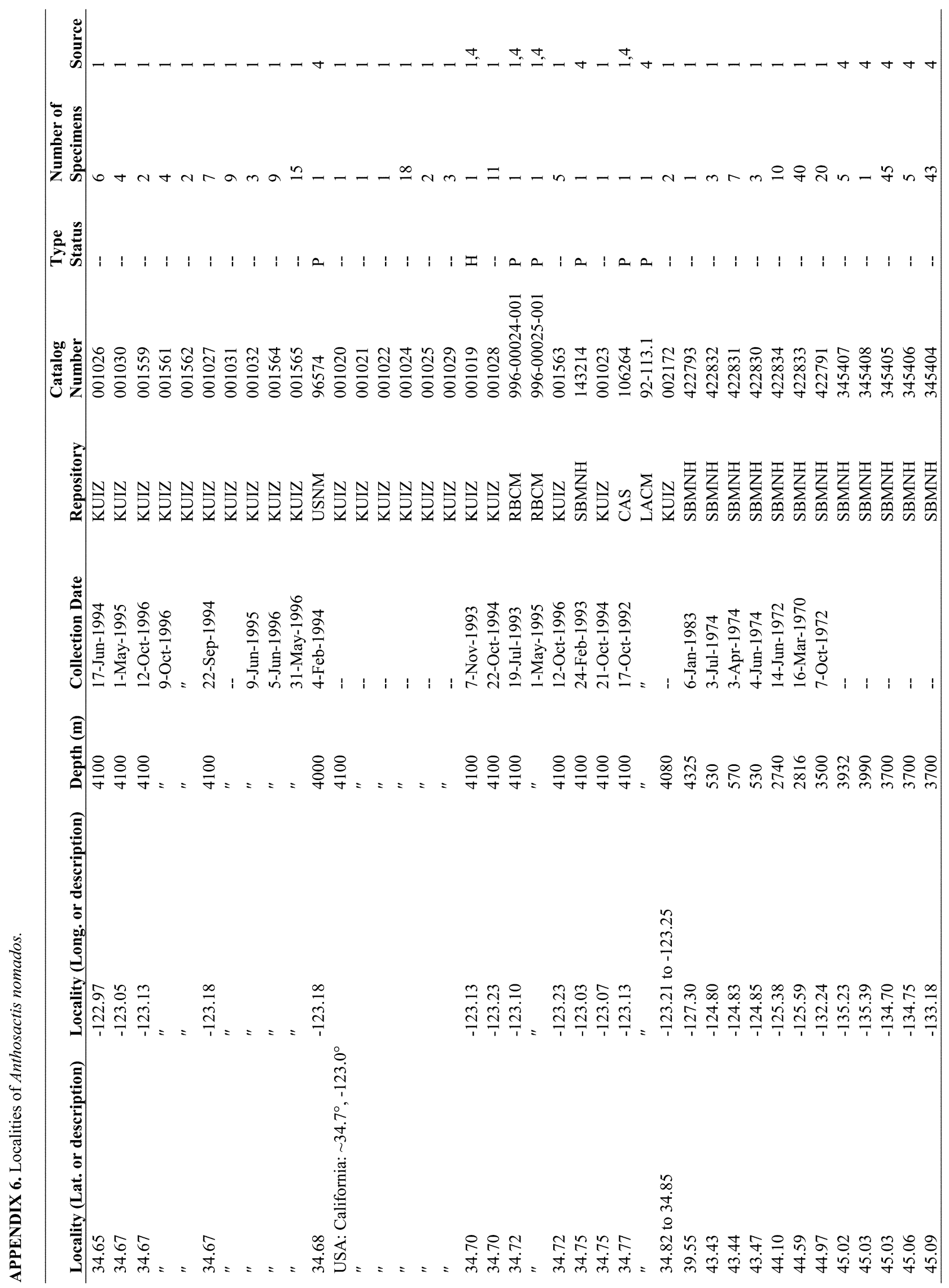




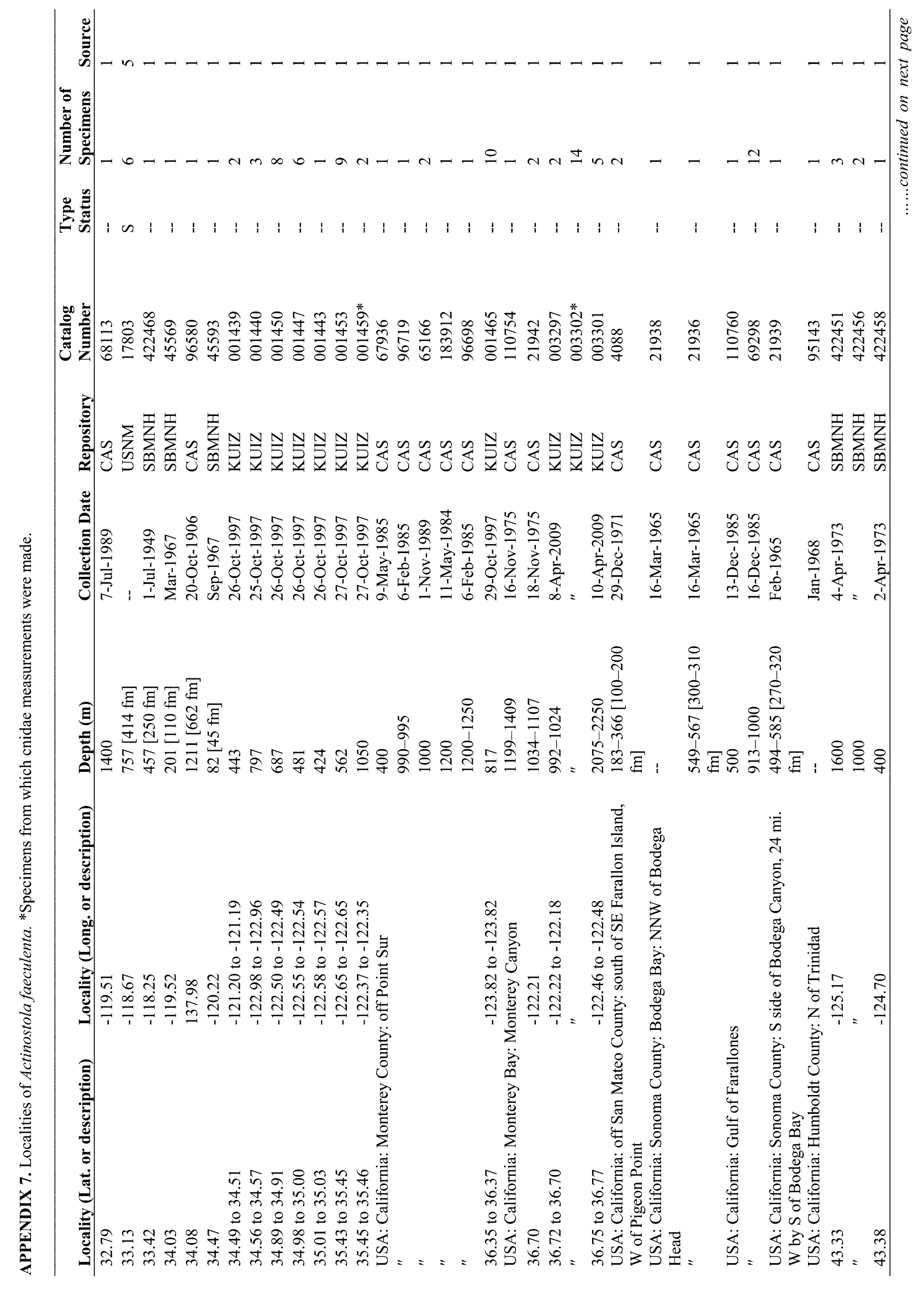









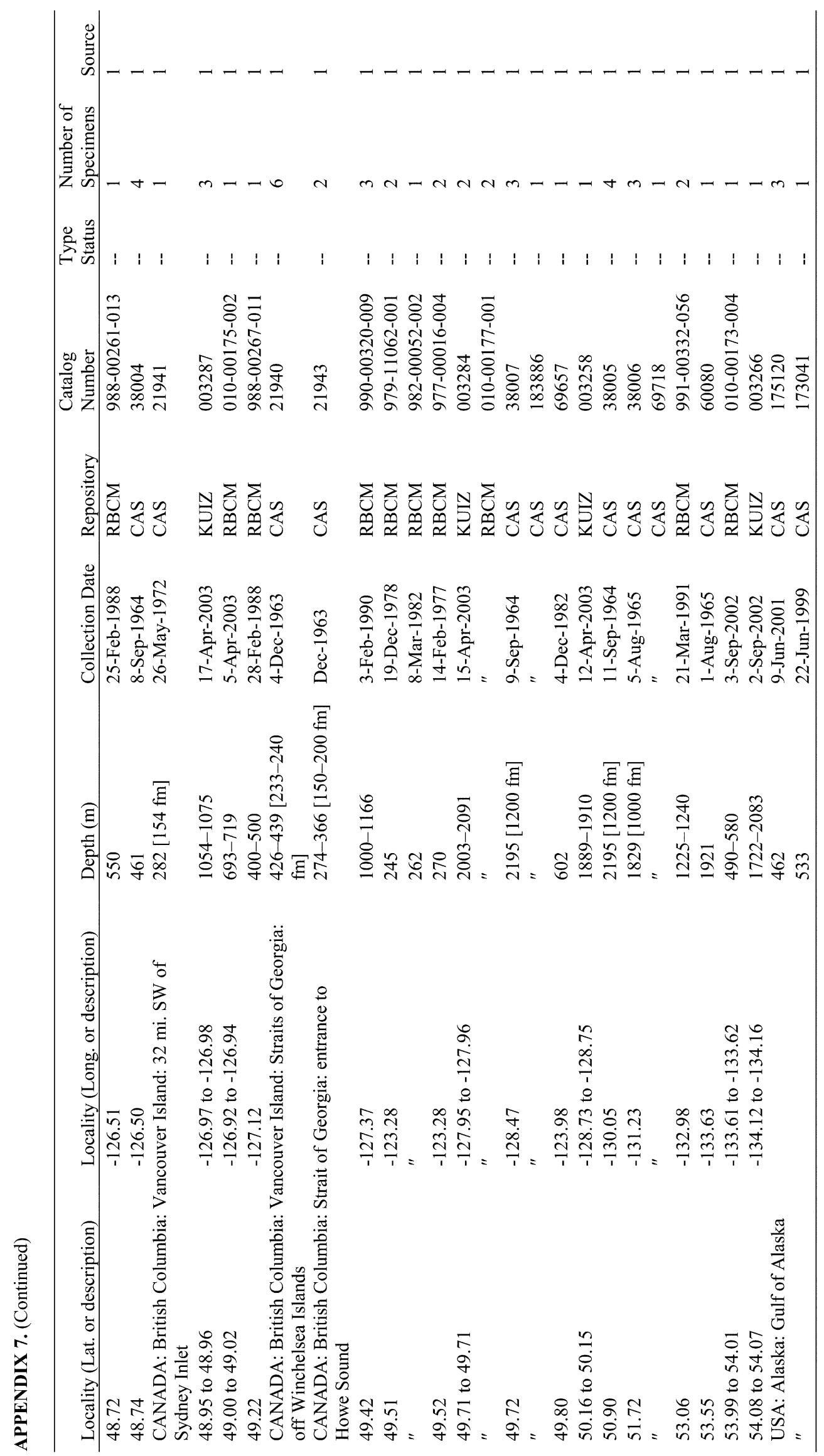




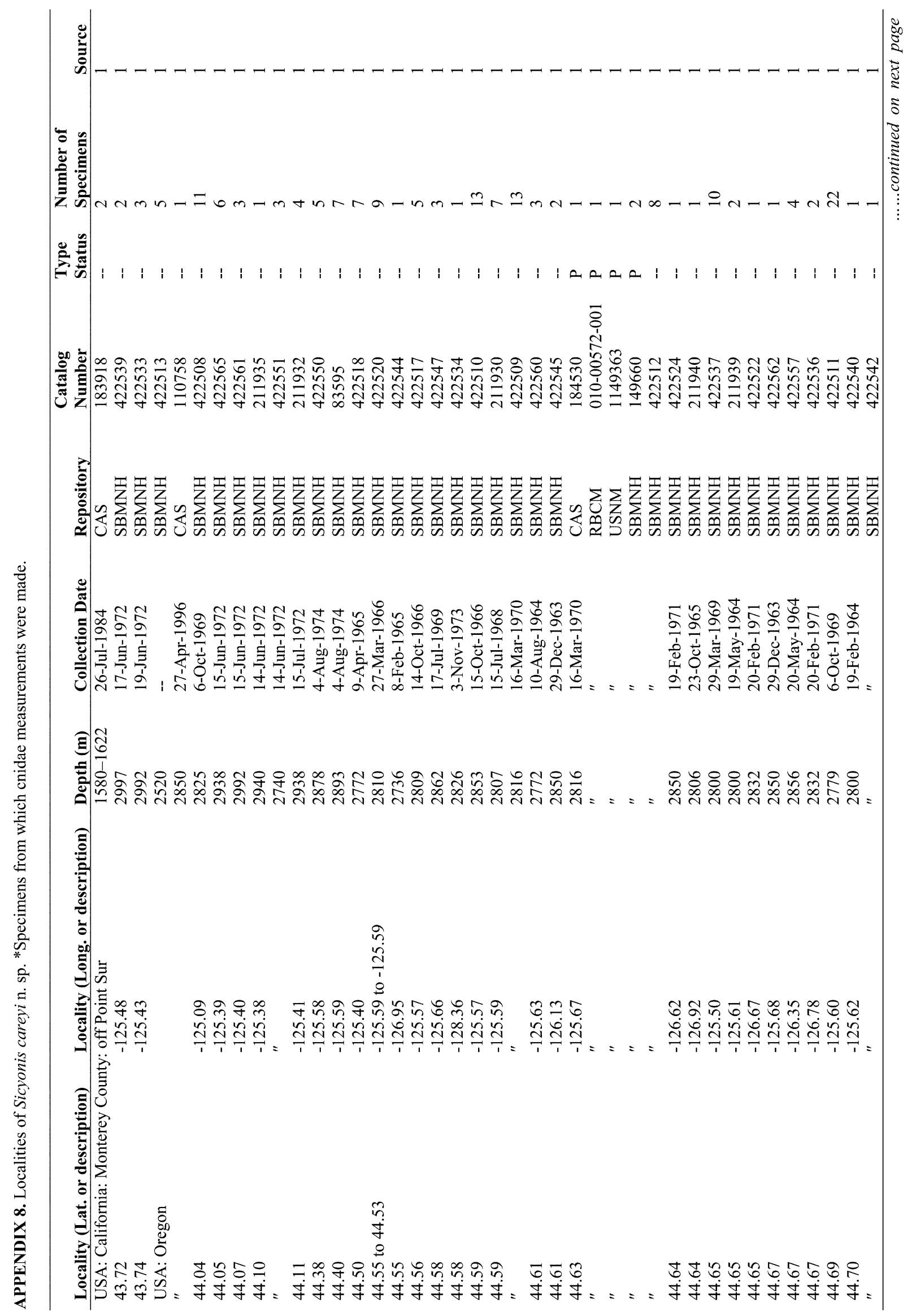




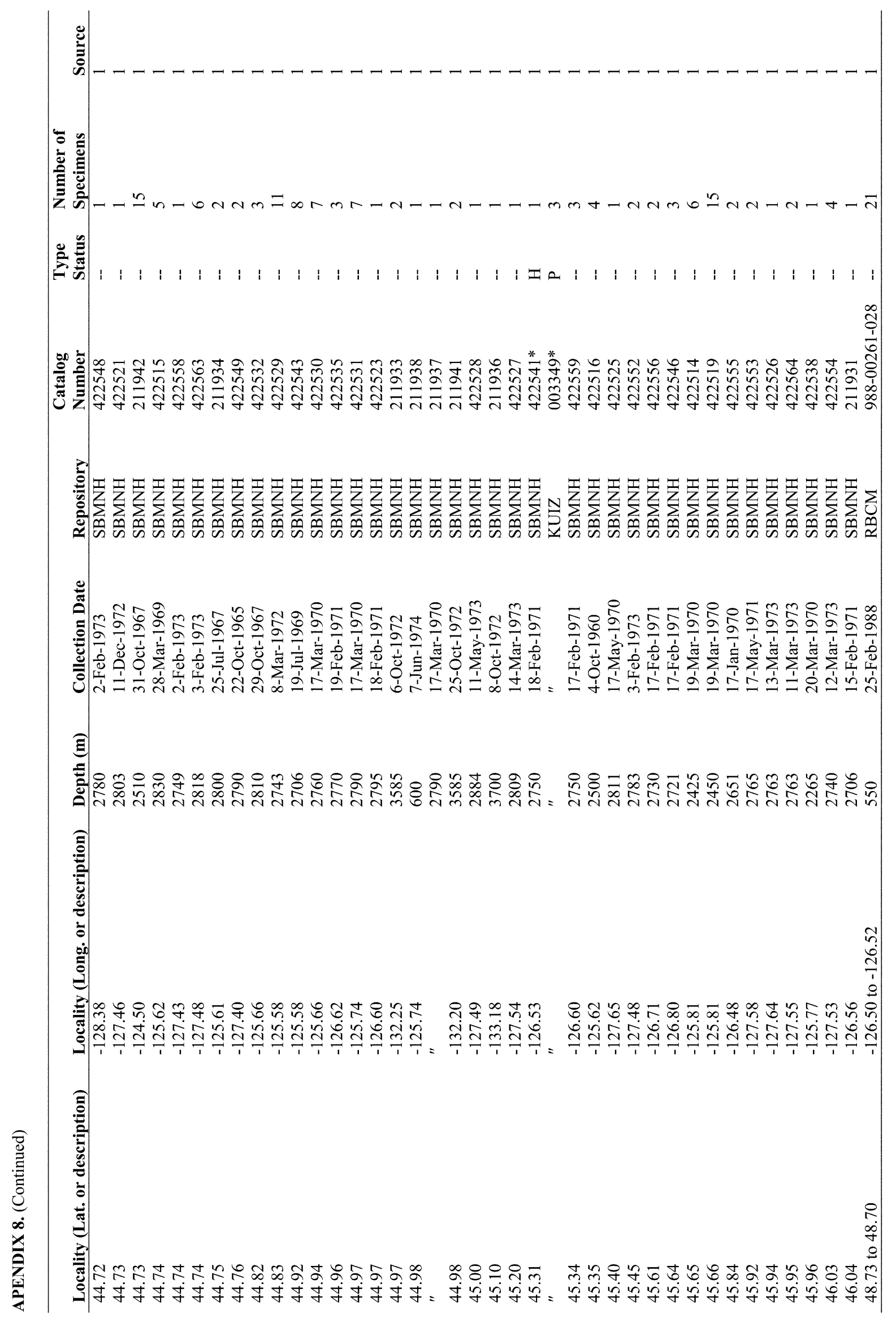




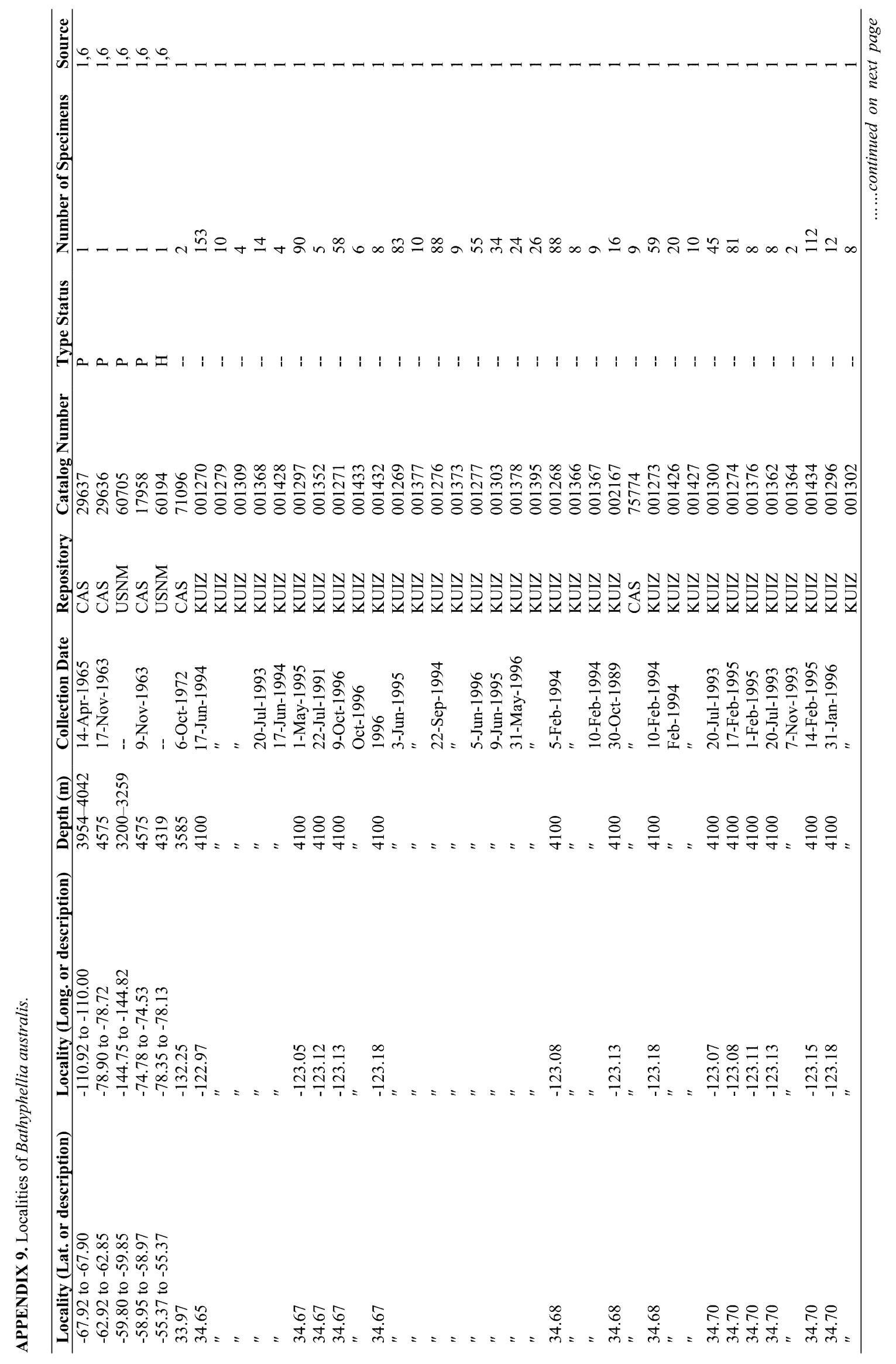














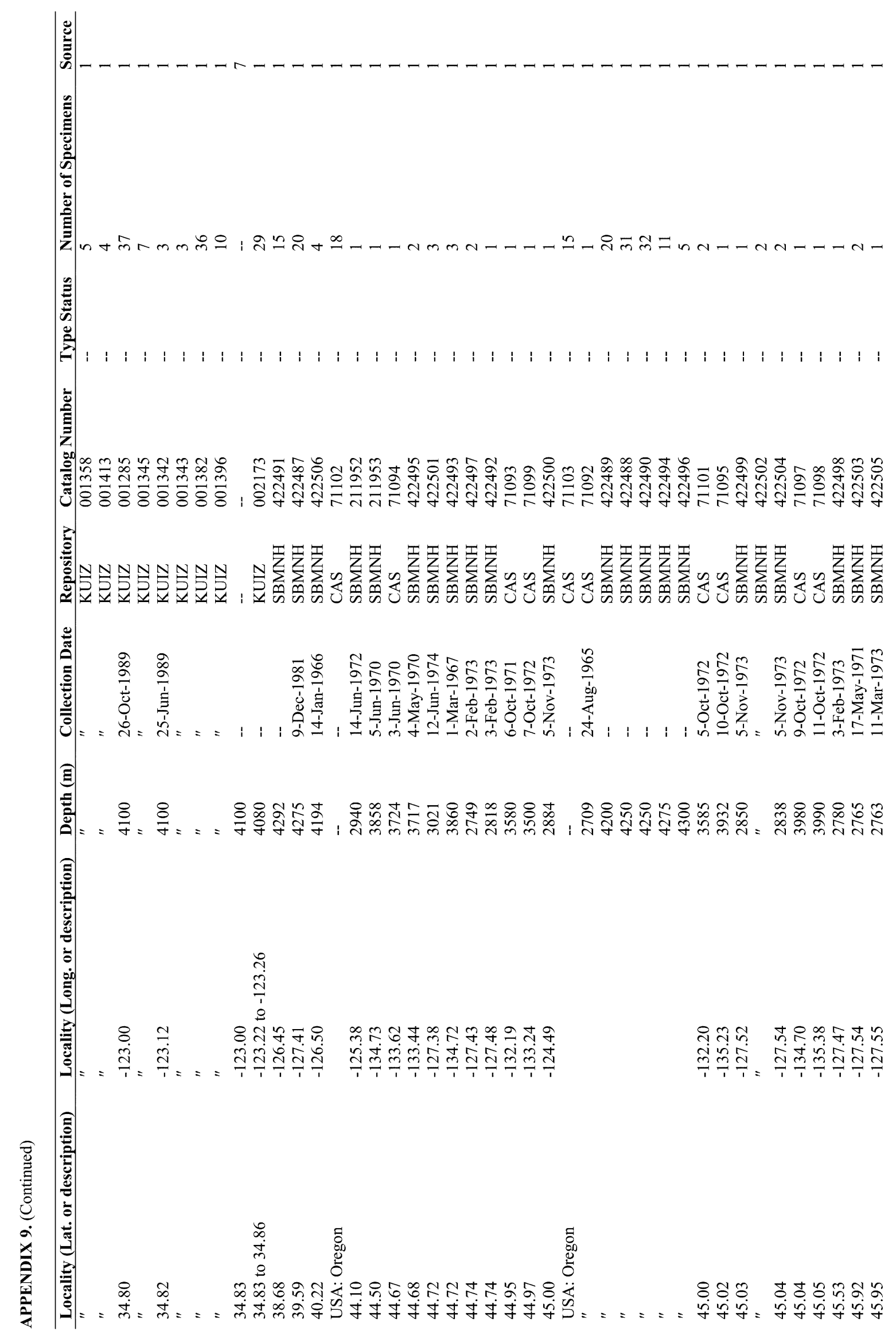









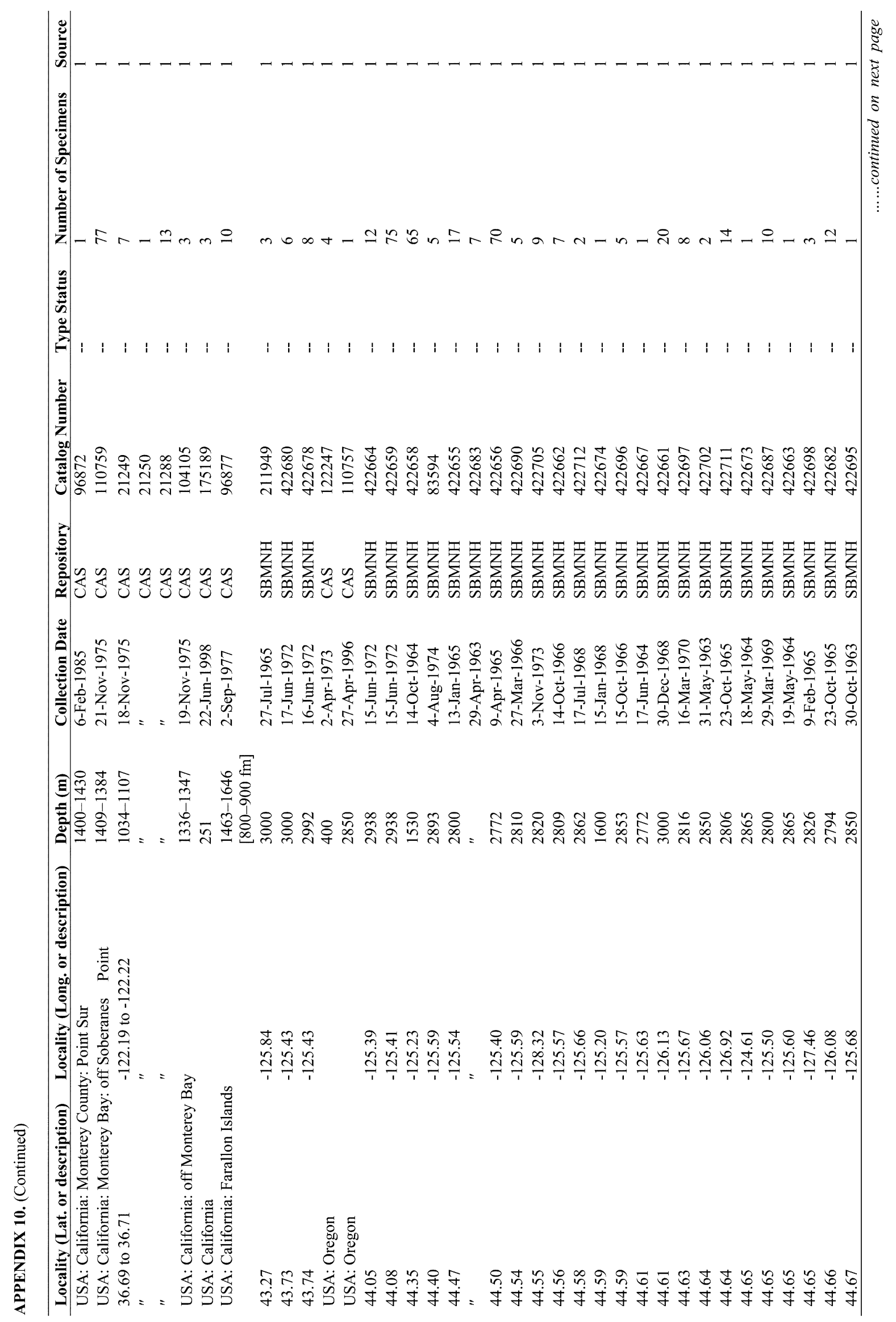




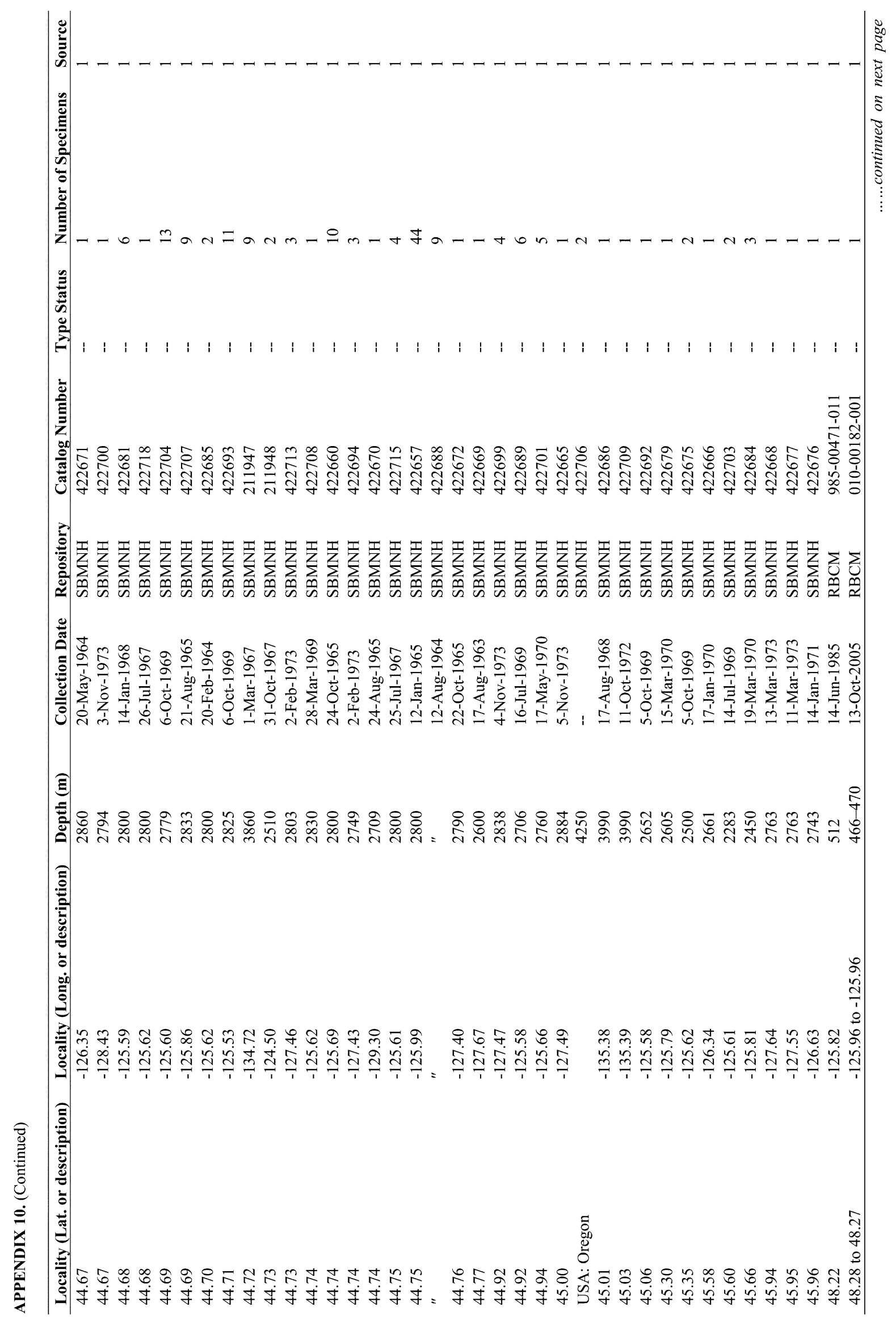




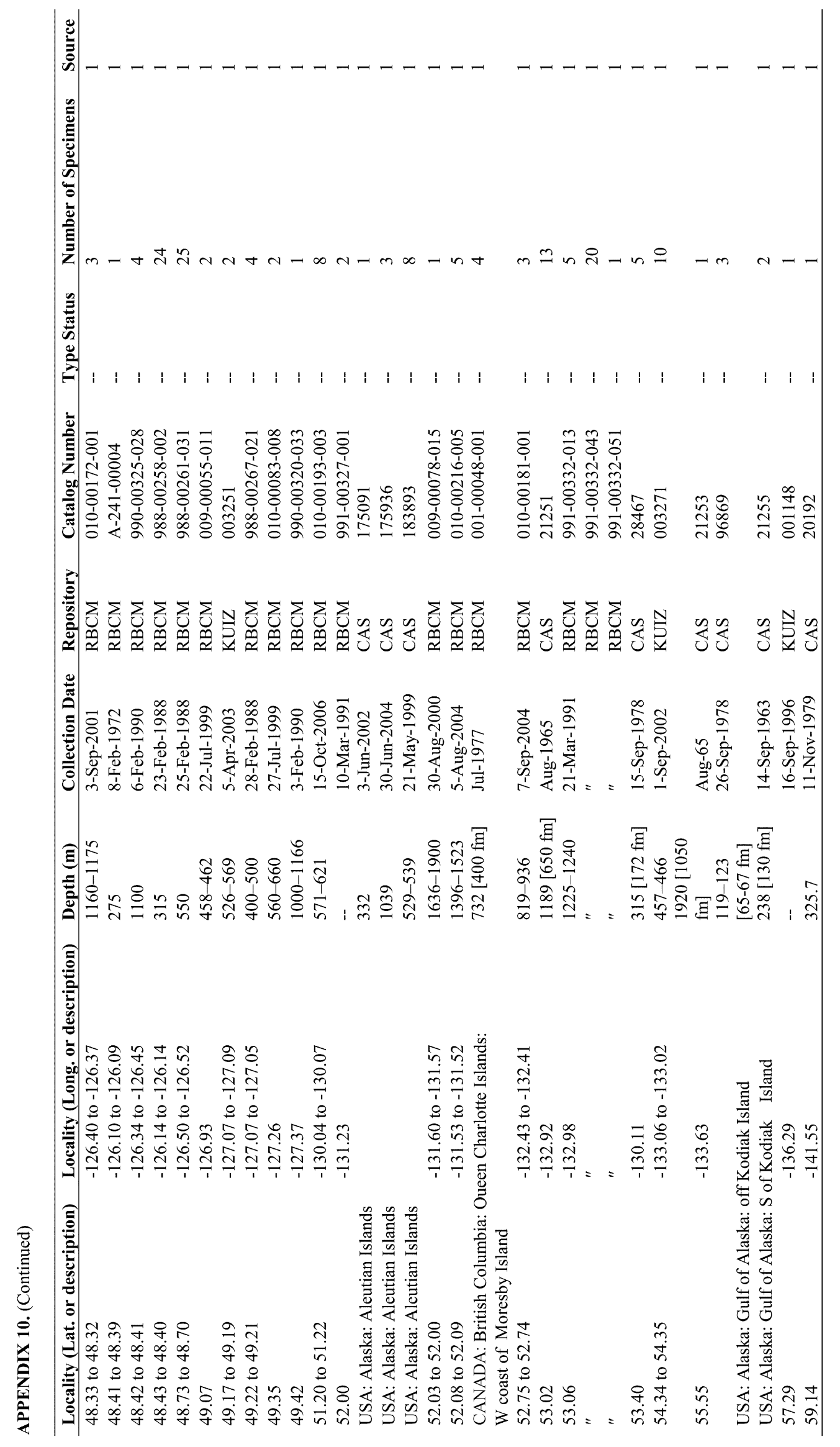
























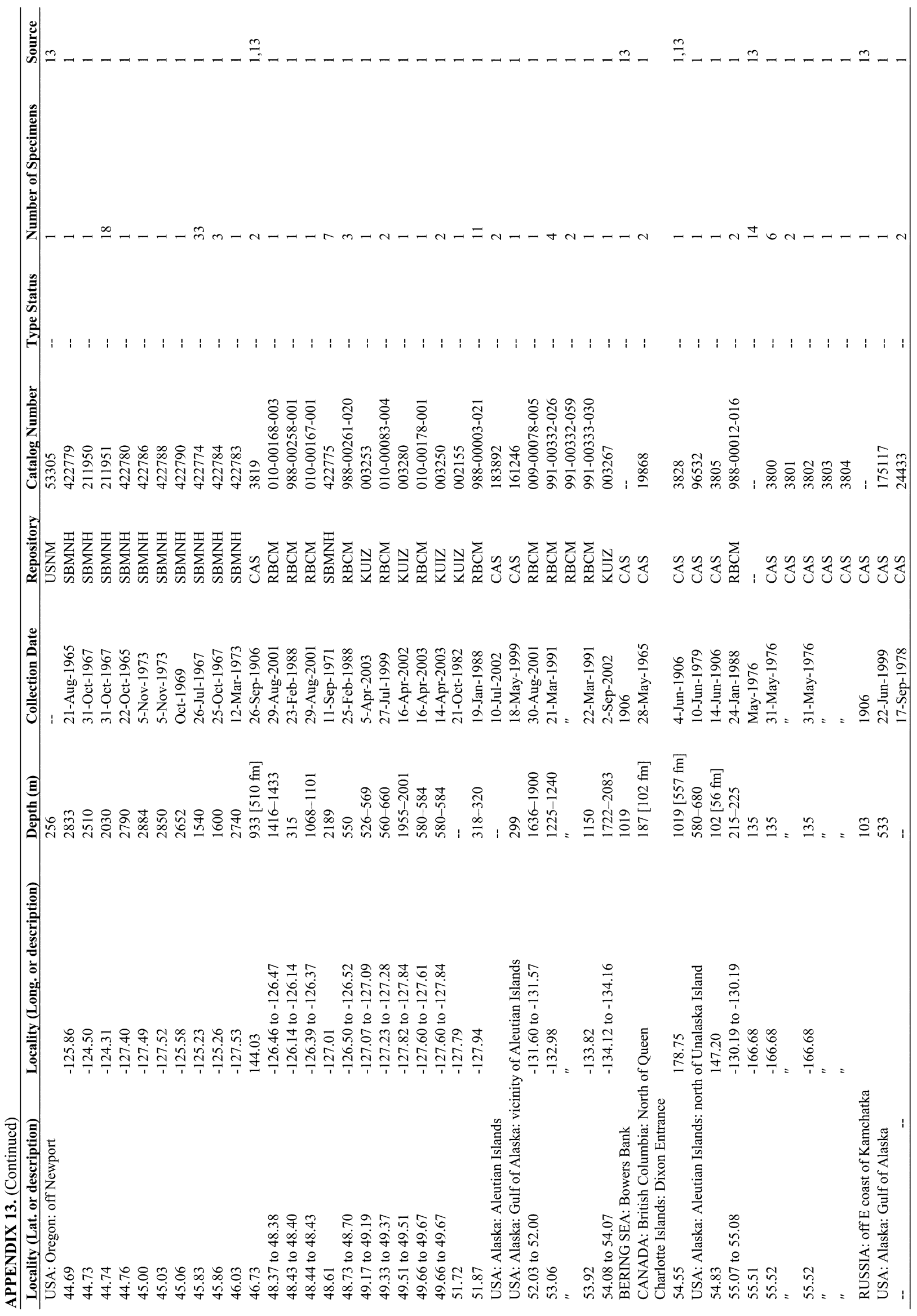




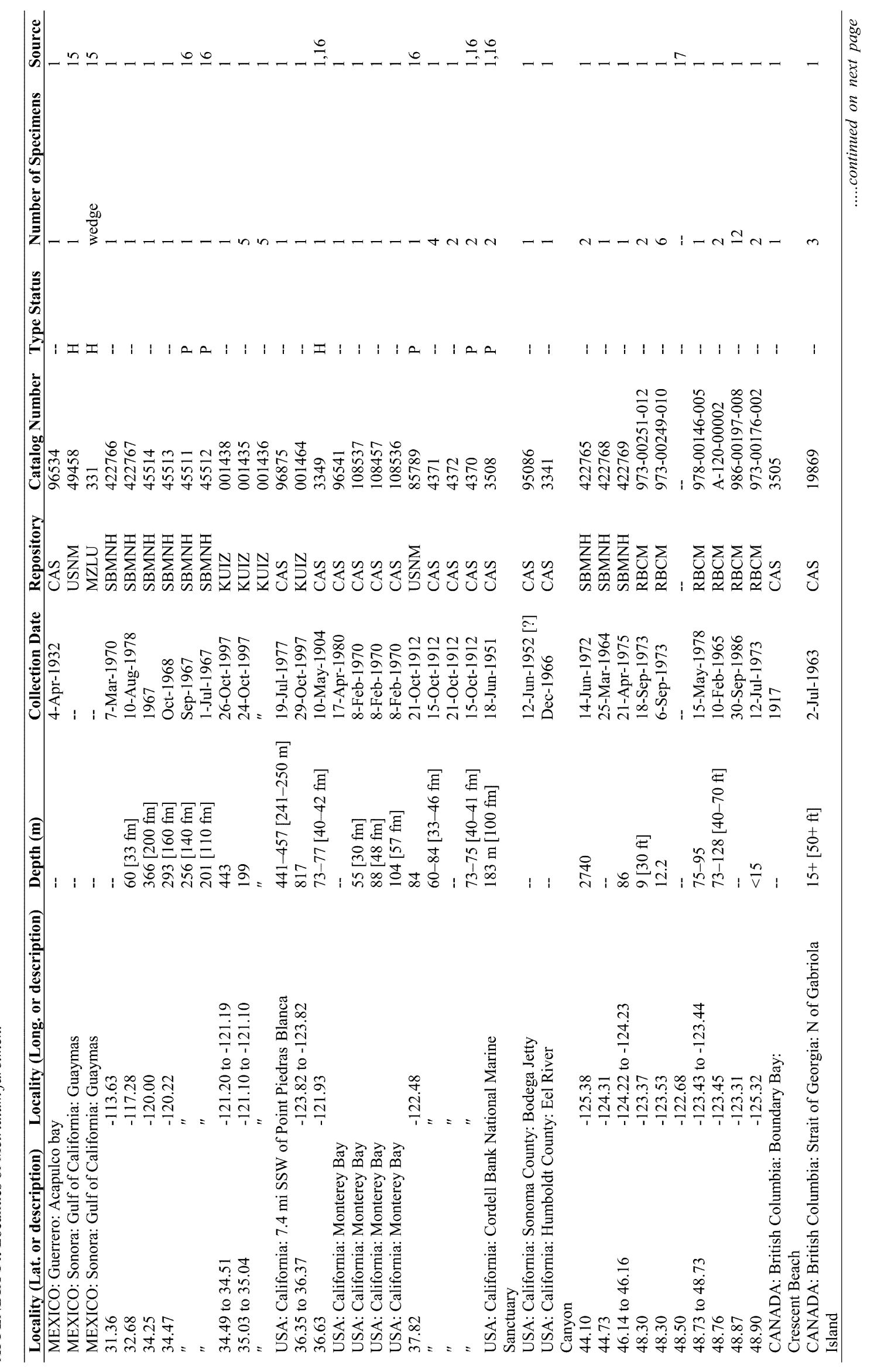




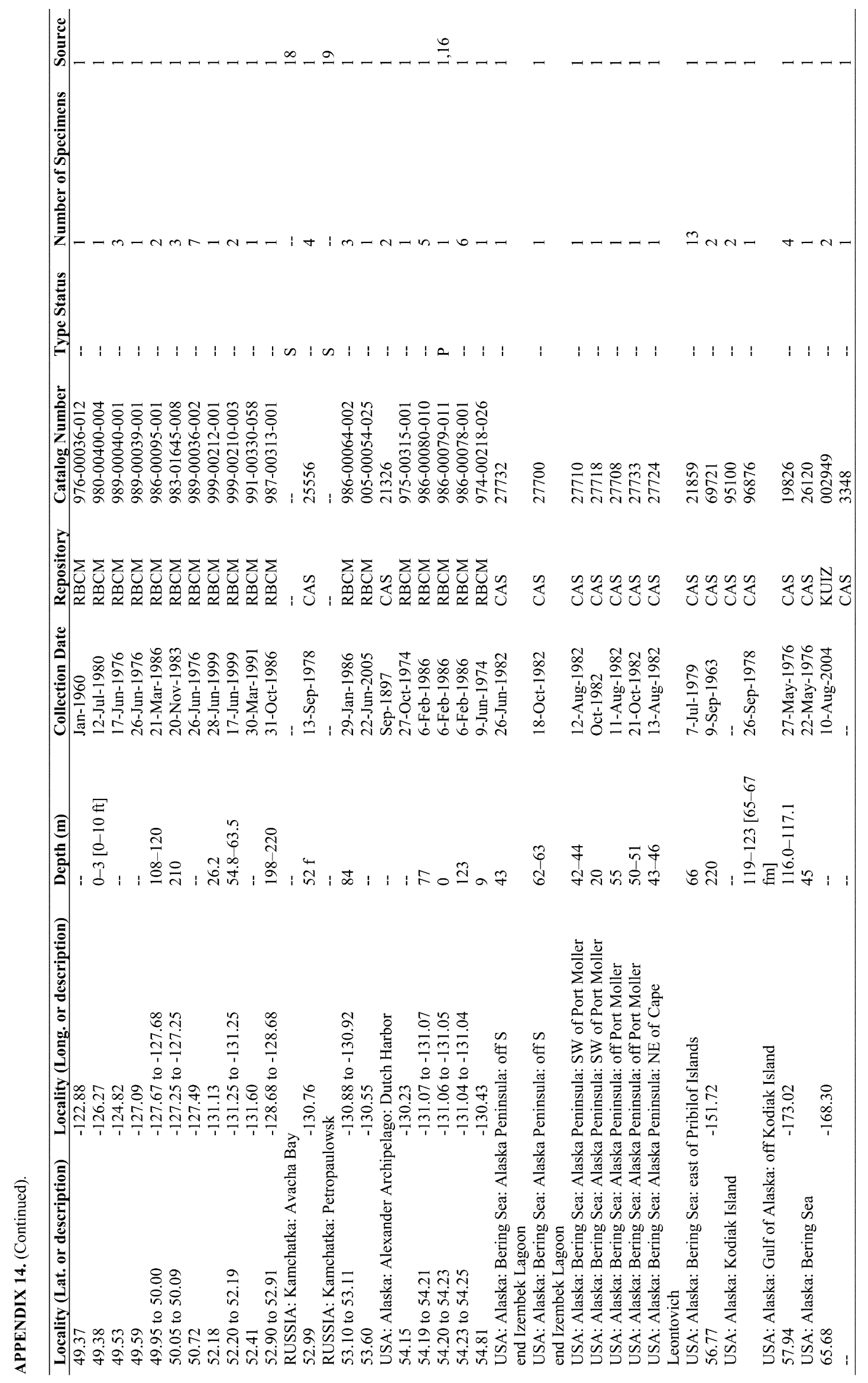




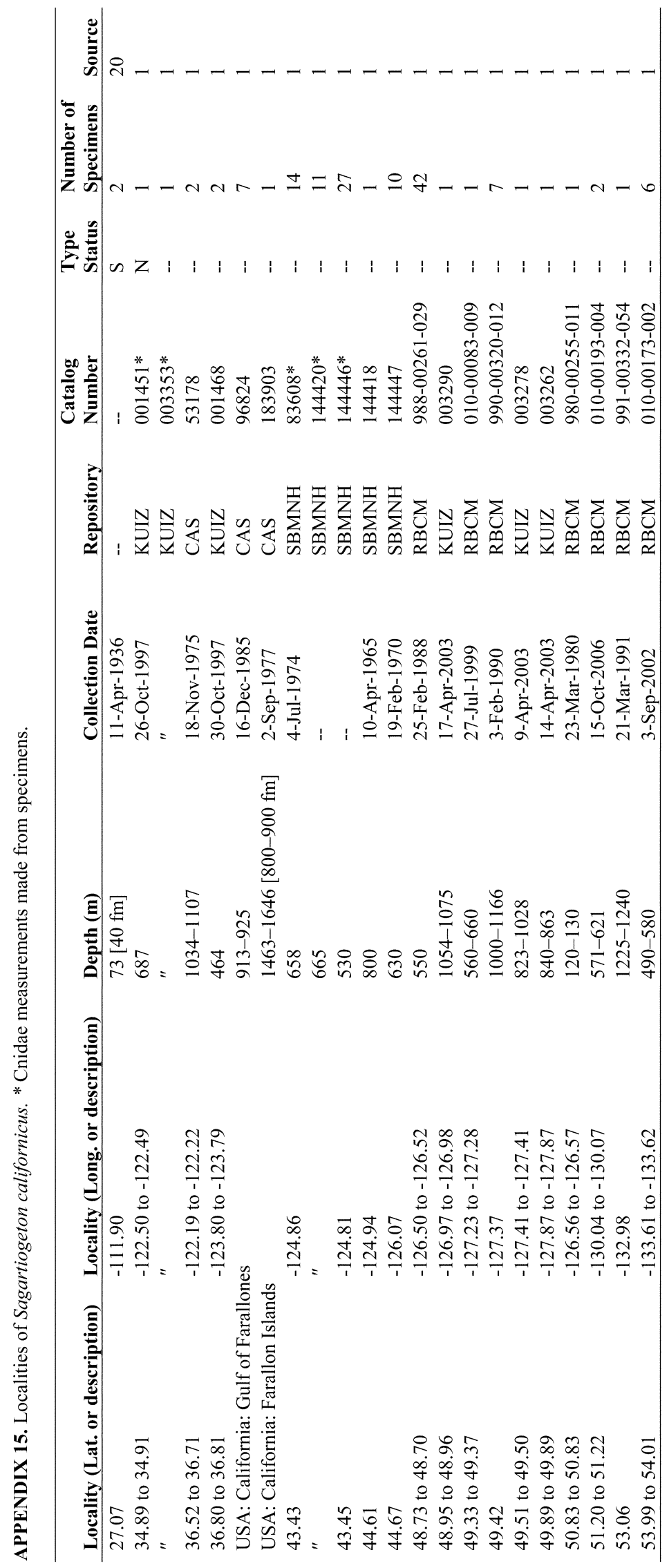

